Pacific Northwest

National Laboratory

Operated by Battelle for the

U.S. Department of Energy

\section{Assessment of the Grouted IXC Monolith in Support of K East Basin Hazard Categorization}

\author{
S. M. Short \\ M.G. Dodson \\ J.M. Alzheimer \\ P.A. Meyer
}

October 2007

Prepared for the U.S. Department of Energy under Contract DE-AC06-76RL01830 


\section{DISCLAIMER}

This report was prepared as an account of work sponsored by an agency of the United States Government. Neither the United States Government nor any agency thereof, nor Battelle Memorial Institute, nor any of their employees, makes any warranty, express or implied, or assumes any legal liability or responsibility for the accuracy, completeness, or usefulness of any information, apparatus, product, or process disclosed, or represents that its use would not infringe privately owned rights. Reference herein to any specific commercial product, process, or service by trade name, trademark, manufacturer, or otherwise does not necessarily constitute or imply its endorsement, recommendation, or favoring by the United States Government or any agency thereof, or Battelle Memorial Institute. The views and opinions of authors expressed herein do not necessarily state or reflect those of the United States Government or any agency thereof.

PACIFIC NORTHWEST NATIONAL LABORATORY

$$
\text { operated by }
$$

BATTELLE

for the

UNITED STATES DEPARTMENT OF ENERGY

under Contract DE-AC06-76RL01830 


\title{
Assessment of the Grouted IXC Monolith in Support of K East Basin Hazard Categorization
}

\author{
S. M. Short \\ M.G. Dodson \\ J.M. Alzheimer \\ P.A. Meyer
}

October 2007

Prepared for

Fluor Hanford

PNNL Project Numbers 49528 and 46980

Work supported by

the U.S. Department of Energy

under Contract DE-AC05-76RL01830

Pacific Northwest National Laboratory

Richland, Washington 99352 


\section{Executive Summary}

The K East Basin currently contains six ion exchange columns (IXCs) that were removed from service over 10 years ago. Three of these IXCs are stored within a concrete vault while the other three IXCs are stored within a lead-lined steel box (cave) that is attached to the concrete vault. In analyses conducted in SNF-22494 (Coles 2005), Pacific Northwest National Laboratory (PNNL) determined that, in their current storage configuration, the IXCs are categorized in accordance with DOE-STD-1027 (DOE 1997) as Hazard Category 3.

Since the publication of SNF-22494, however, Fluor Hanford has developed an alternative approach to decommissioning the IXCs. The new approach is to immobilize the six ion exchange columns (IXCs) in place. This is to be done by filling the void space between the IXCs and their associated storage structures with grout, creating a grout monolith that can later be removed as a single package for disposal. PNNL evaluated this alternative approach from a facility hazard categorization perspective to identify poptential design specifications for the grouted monolith that may support downgrading of the K East Basin to less than a Hazard Category 3 Facility.

In the first step of this evaluation, a Preliminary Hazard Analysis session was held with knowledgeable K Basin Closure Project staff from which potential bounding hazardous conditions were identified for the grouted IXC monolith. Three hazardous conditions resulting in a postulated radioactive release were selected as potentially bounding. Two hazardous conditions are load drop events. In one, MED-2-09, the grouted monolith is dropped while it is being moved onto a transporter. In the other, MED-2-11, equipment/materials being moved during decommissioning and demolition operations are dropped/fall onto the grouted monolith (e.g., falling crane boom, dropped I-beam). In the third hazardous condition, MED-2-12, a heavy vehicle such as a monolith transport carrier tractor runs into the monolith and damages the tractor fuel tank which leads to a fire.

PNNL then performed a structural assessment of the concrete monolith to determine its capability to absorb the forces imposed by the postulated accidents and protect the IXCs from damage and thus prevent a release of radioactive material. From this assessment, design specifications for the concrete monolith were identified that would prevent a release of radioactive material for any of the postulated hazardous conditions. These design specifications are as follows:

- Ensure a minimum of 5 inches of grout/concrete between the walls of the IXC and the outer walls of the monolith. This thickness of grout/concrete will provide sufficient fire resistance to protect the IXCs from a 2-hour fire. The IXC Vault, as currently configured, already meets this requirement. The IXCs in the IXC Cave would need to either be moved so as to abut up next to the IXC Vault wall and the cave filled with grout/concrete or additional concrete structure would need to be constructed around the outside of the cave sufficient to create the required 5-inch thickness.

- Incorporate a minimum 0.5 -inch thick steel plate surrounding all externally-exposed horizontal sides of the IXC Cave. This steel shield will distribute the force from the impact of a vehicle collision sufficiently to protect the IXCs in the IXC Cave from 
significant damage. Alternatively, a 1-foot thick reinforced concrete wall surrounding all externally exposed sides of the IXC would provide the same protection as the steel plate. In either case, the steel/reinforced concrete must be anchored to the existing concrete vault structure. The existing slightly reinforced concrete IXC Vault is judged to be adequate to protect the IXCs in this vault from significant damage from a vehicle collision.

- Incorporate a minimum 0.5 -inch thick steel plate covering the entire top of the concrete monolith. This steel shield will distribute the force from the impact of the postulated falling/dropped objects sufficiently to protect the IXCs from significant damage. This steel plate must be anchored to the concrete monolith.

- Ensure that the NUCFIL Filter is not plugged by any aggregate that may be included in the grout/concrete. The analysis in this report showed that over-pressurization of the IXCs from gas generation due to radiolysis is not an issue as long as the NUCFIL Filter is not plugged by aggregate. This recommendation can be achieved by either not including aggregate in the grout/concrete used to fill the void spaces between the IXCs and the vault/cave interior walls or by removing the NUCFIL Filter and leaving the 3-inch IXC inlet opening exposed to the grout/concrete fill.

These conclusions and recommendations are supported as long as the accident conditions assumed in the structural assessment, which are believed to be conservative, are not exceeded. 


\section{Contents}

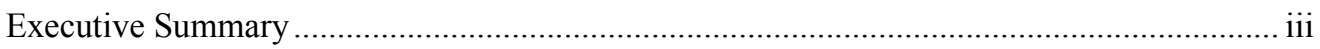

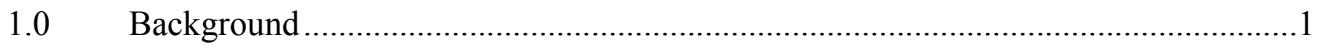

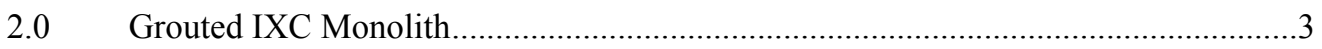

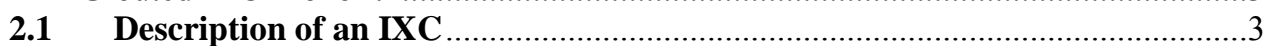

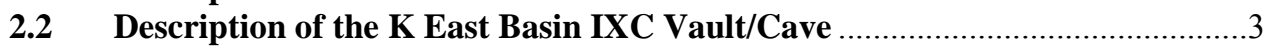

$2.3 \quad$ Grouted IXC Monolith Concept....................................................................

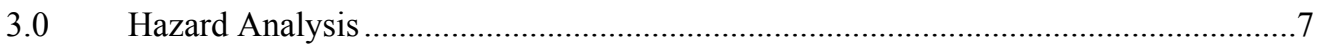

3.1 Summary of Preliminary Hazard Analysis ..................................................

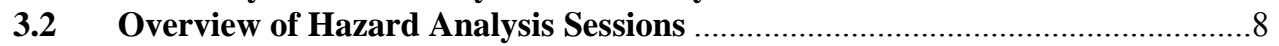

4.0 Hazard Categorization Analysis …………......................................................11

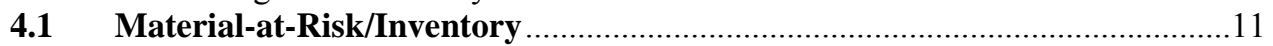

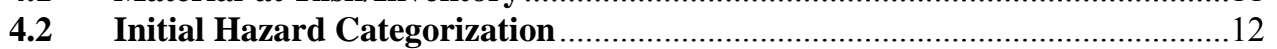

4.3 Hazard Categorization Utilizing Adjusted TQVs.......................................13

5.0 Grouted IXC Monolith Structural Assessment ........................................................19

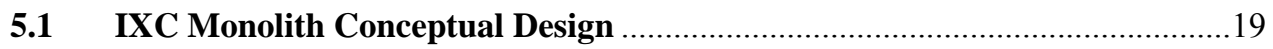

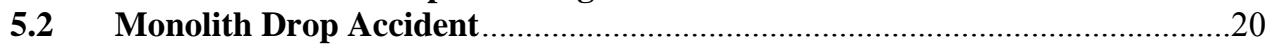

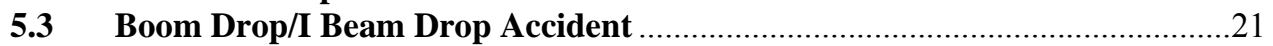

$5.4 \quad$ Vehicle Impact and Subsequent Fire Accident …….......................................22

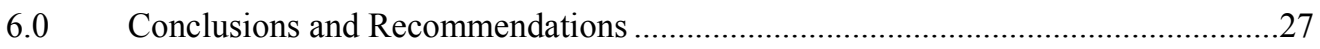

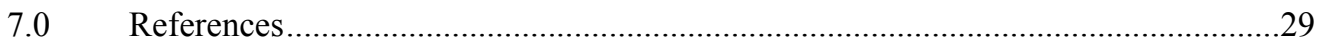

Appendices

A Preliminary Hazard Analysis Session Participants ............................................. A-i

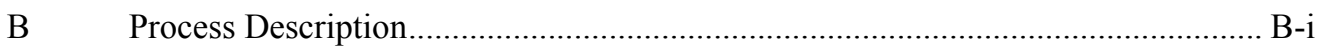

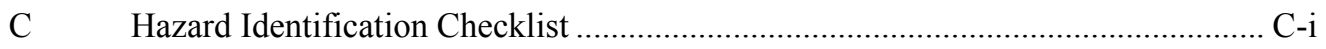

D Preliminary Hazards Assessment Worksheets .................................................... D-i

E Analysis of the Potential for Pressurization of an Ion Exchange Column Immobilized in Concrete.................................................................................... E-i

Addendum

I Addendum to PNNL-15401 Regarding Structural Assessment of I-Beam

Drop Accident AD-i 


\section{Tables}

Table 3-1. Representative Bounding Hazardous Conditions ...................................................

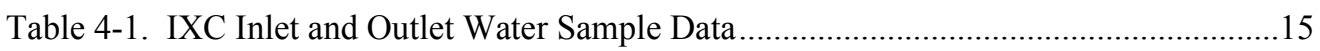

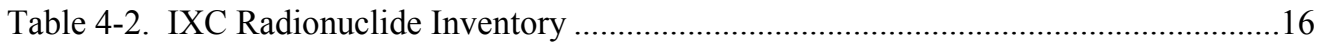

Table 4-3. K East Basin Initial Hazard Categorization Based on IXC Radionuclide

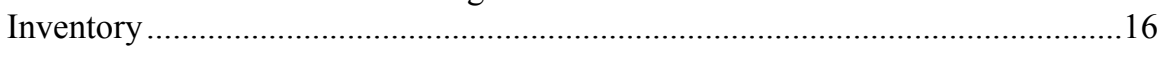

Table 4-4. K East Basin Final Hazard Categorization for Grouted IXC Drop Accident.........17

Table 4-5. K East Basin Final Hazard Categorization for Vehicle Collision and Subsequent Fire Accident ....................................................................................17

\section{Figures}

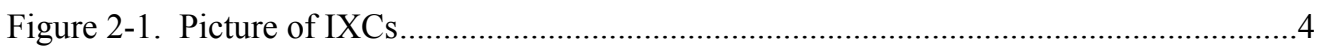

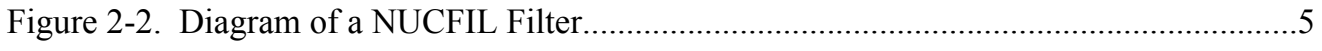

Figure 2-3. Top View Drawing of the IXC Vault and Cave...................................................

Figure 2-4. Side View Drawing of the IXC Vault .................................................................6

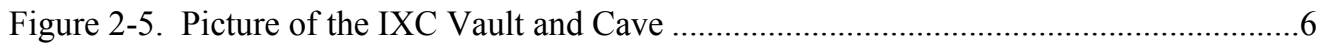

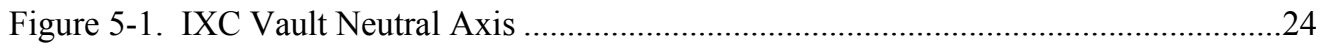

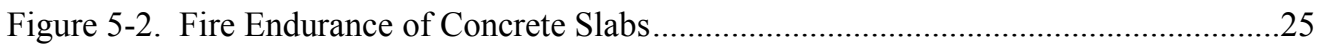




\subsection{Background}

The K East Basin currently contains six ion exchange columns (IXCs) that were removed from service over 10 years ago. Three of these IXCs are stored within a concrete vault while the other three IXCs are stored within a lead-lined steel box (cave) that is attached to the concrete vault. In analyses conducted in SNF-22494 (Coles 2005), Pacific Northwest National Laboratory (PNNL) determined that, in their current storage configuration, the IXCs are categorized in accordance with DOE-STD-1027 (DOE 1997) as Hazard Category 3.

Since the publication of SNF-22494, however, Fluor Hanford has developed an alternative approach to decommissioning the IXCs. The new approach is to immobilize the six ion exchange columns (IXCs) in place. This is to be done by filling the void space between the IXCs and their associated storage structures with grout creating a grout monolith that can later be removed as a single package for disposal. PNNL evaluated this alternative approach from a facility hazard categorization perspective to identify potential design specifications for the grouted monolith that may support downgrading of the K East Basin to less than a Hazard Category 3 Facility. 
This page intentionally left blank. 


\subsection{Grouted IXC Monolith}

\subsection{Description of an IXC}

The following description of an IXC is taken from WHC-SD-SNF-SARR-003, Section 3 (WHC 1994).

The housing of an IXC is 18 -inch outer diameter Schedule 10 pipe with 0.25 -inch thick walls (17.5-inch inner diameter). The IXC is 59 inches long with the ion exchange bed occupying the middle 41 inches when swelled. The column is designed for $75 \mathrm{psig}$ and tested at 125 psig. The burst strength of 18 -inch Schedule 10 pipe is about 20 times greater based on ultimate strength and hoop stress. Even considering stress intensification around welds and holes (stress intensification factors of 2 to 4 ), the burst strength is still five times that of design. This implies that the design pressure is based on loads of the column internals and not the burst strength of the Schedule 10 pipe. Figure 2-1 provides a picture of an IXC.

When an IXC is removed from service, a plug is placed in the 3 -inch inlet opening (see top of IXC in Figure 2-1), the gate valve on the bottom of the IXC is opened, and the water in the column drains out. After 24 hours of draining has elapsed the drain valve is closed and a NUCFIL filter is installed in the inlet pipe opening. The filter consists of a 1-inch outer diameter, 0.73-inch inner diameter, 0.78 -inch long threaded steel body. The filter occupies the interior of the body. There is a $1 / 8$-inch diameter opening in the front and back of the filter. The filter is threaded into a $3 / 4$-inch pipe connector the other end of which is welded to a 2 -inch plug. Vendor data shows that the filter contains a cap that has a 1/8-inch hole in it. Figure 2-2 provides a diagram of the filter.

\subsection{Description of the K East Basin IXC Vault/Cave}

Three IXCs are currently stored in the IXC Vault. The IXC Vault is a minimal reinforced concrete structure having dimensions of 15 -ft long, 6 - $\mathrm{ft}$ wide, and 11-ft tall. The three IXCs are loaded vertically into individual $4-\mathrm{ft}$ square cells from the top of the vault. There is approximately 18 inches of concrete between the nearest wall of each cell and at least 18 inches of concrete between the edge of each cell and the edge of the vault. Each of the IXC cells is covered with a 18-inch thick concrete plug. Figures 2-3 and 2-4 provide top and side view drawings, respectively, of the IXC Vault.

Three IXCs are also currently stored in the IXC Cave. The IXC Cave is a steel enclosure having dimensions of 15 - $\mathrm{ft}$ long, 2.5 - $\mathrm{ft}$ wide, and about 8 - $\mathrm{ft}$ tall. The cave is attached to the South face of the IXC Vault. The cave contains storage locations for six vertical IXCs, of which only three are occupied by IXCs. The exterior walls of the cave are lined with lead blankets for shielding. Figure 2-3 also provides a schematic of the IXC Cave and its location relative to the IXC Vault. Figure 2-5 provides a picture if the IXC Vault and Cave and their position relative to the Ion Exchange Modules (IXMs). 


\subsection{Grouted IXC Monolith Concept}

During deactivation and decommissioning (D\&D) of the K East Basin, Fluor Hanford is considering converting the IXC Vault and Cave into a single large concrete monolith for later removal and disposal. The basic concept is to first fill all void spaces between the IXCs and the vault and cave with grout so as to entomb all of the IXCs in a single monolith. The second step is then to add structure to the exterior of the vault/cave sufficient to prevent a release of material during any postulated accident during D\&D. The additional structure would be steel plates attached to and surrounding the entire cave/vault monolith, additional concrete walls surrounding the entire cave/vault monolith, or a combination of the two. Finally additional structure would be incorporated onto the exterior of the monolith if required for later removal, transportation, and disposal.

The initial starting concept for this analysis was the addition of a 1-ft thick concrete wall surrounding the entire cave/vault structure and void space filling with grout/concrete as required to create a single solid concrete monolith (only the interior of the IXCs would contain void space or remain ungrouted). The purpose of this analysis, however, is to determine the minimal additional wall thickness (concrete or steel) required to prevent a release of material during any postulated accident during D\&D. The next section of this report describes the results of a hazards analysis that identified postulated bounding accidents during D\&D.

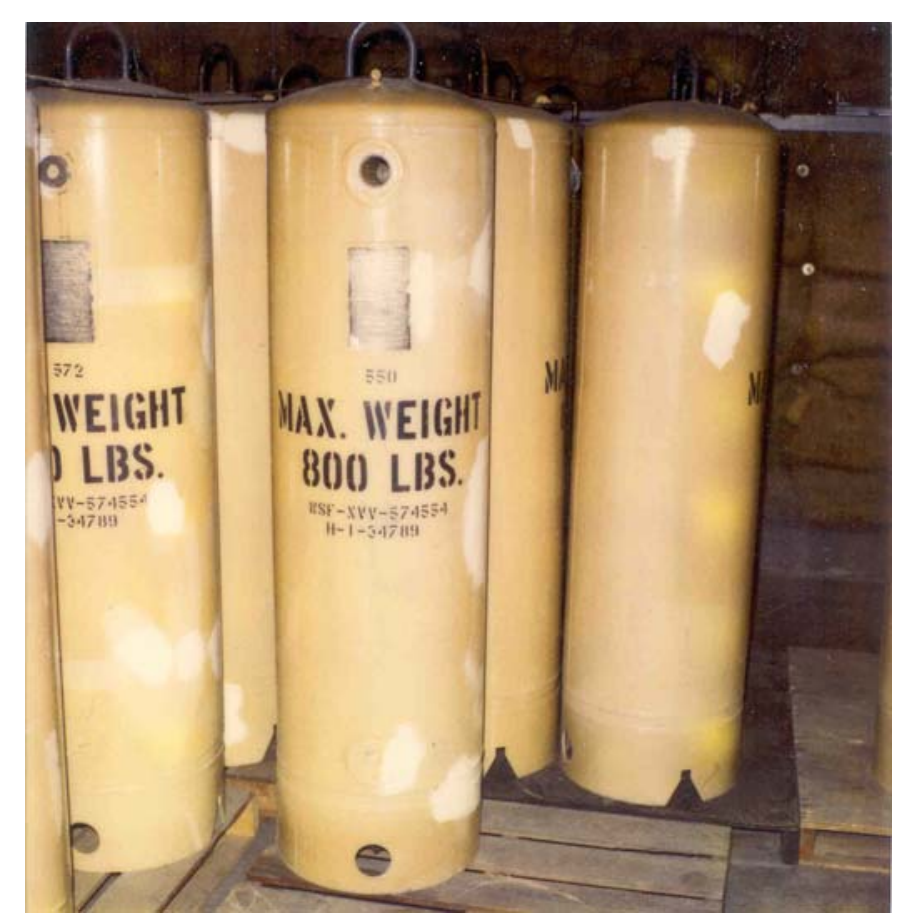

Figure 2-1. Picture of IXCs 


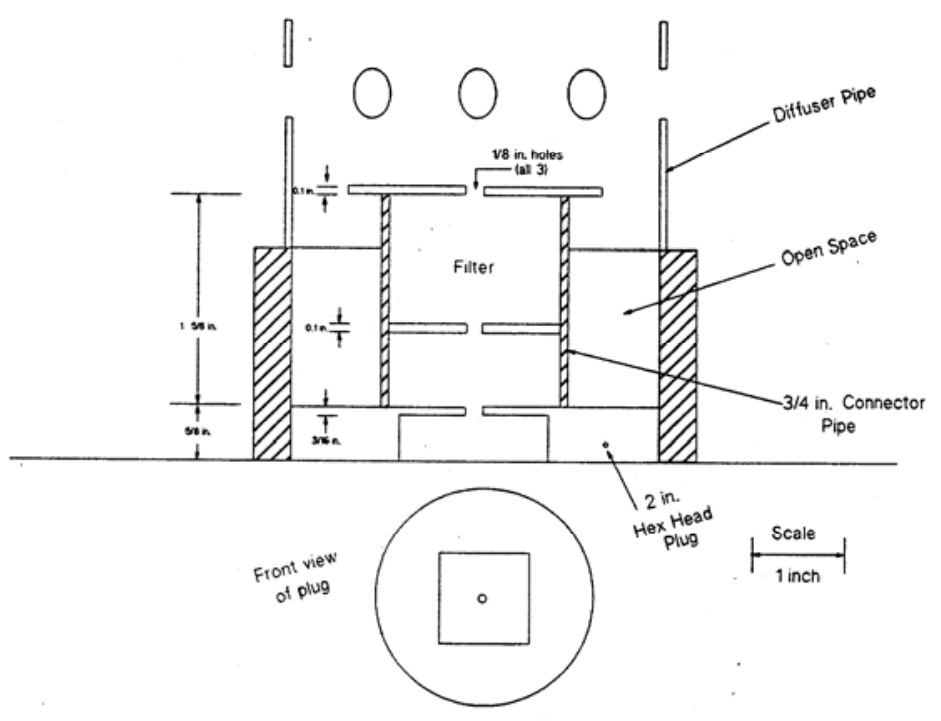

Figure 2-2. Diagram of a NUCFIL Filter

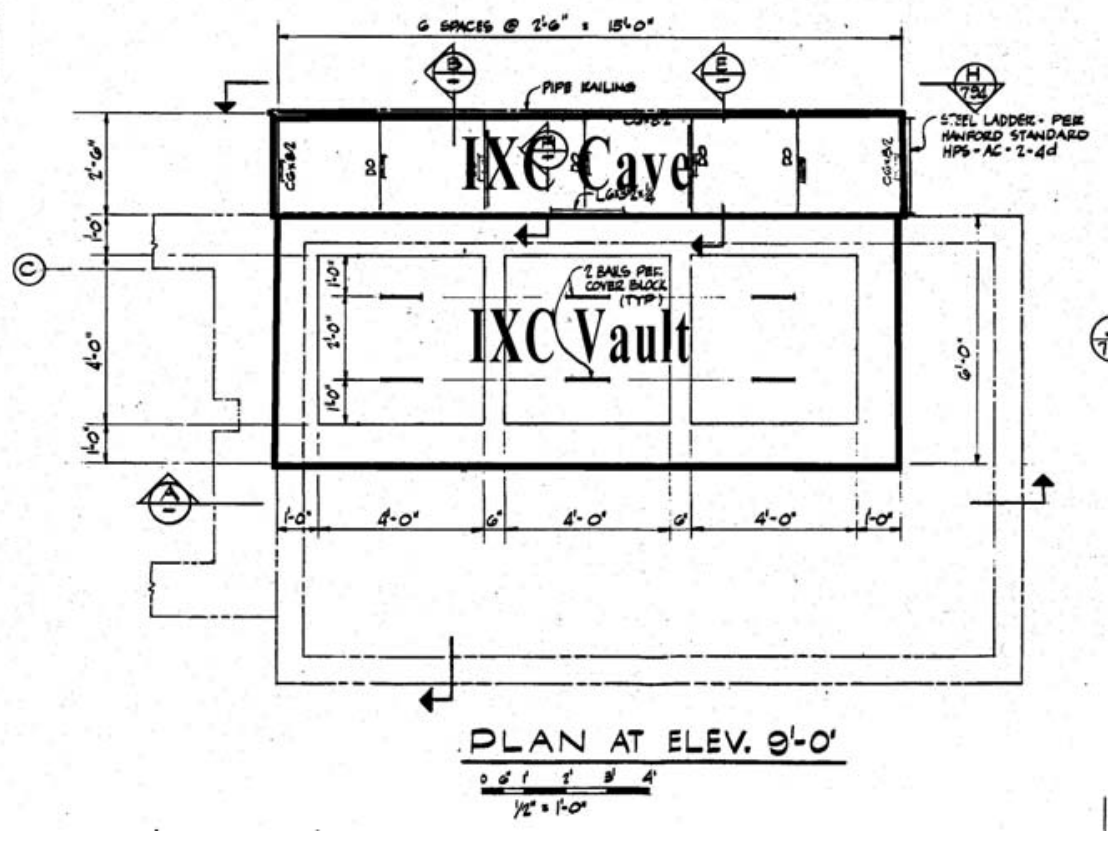

Figure 2-3. Top View Drawing of the IXC Vault and Cave 


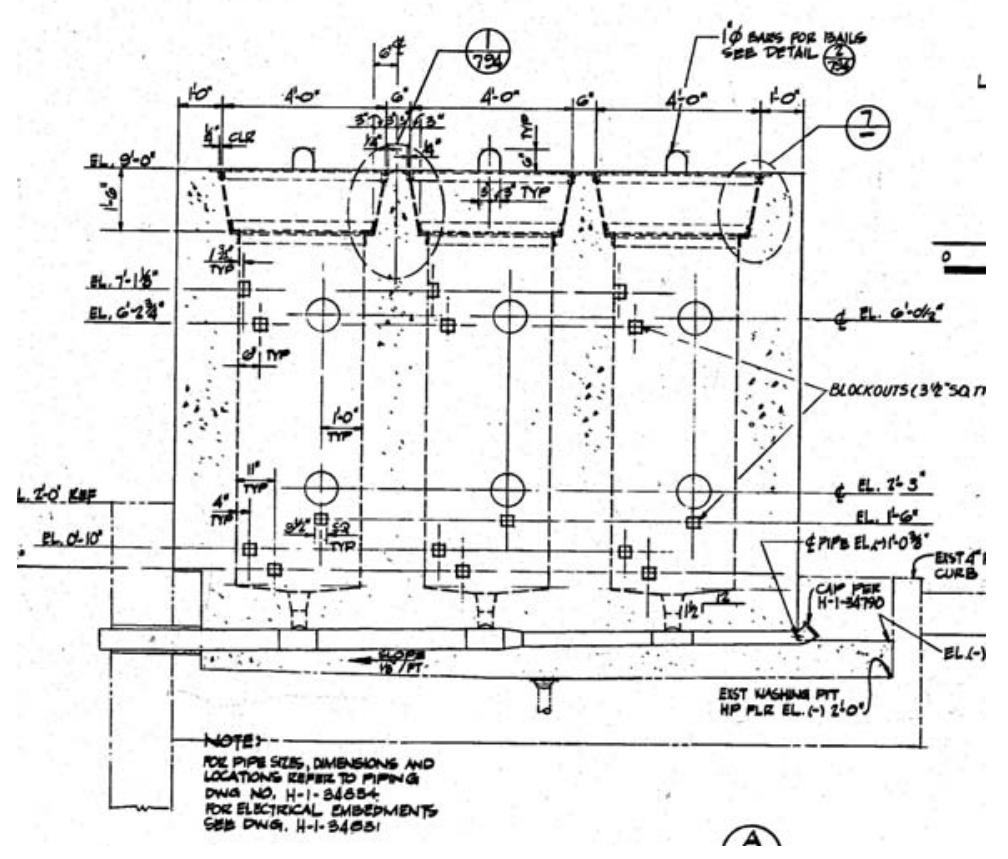

Figure 2-4. Side View Drawing of the IXC Vault

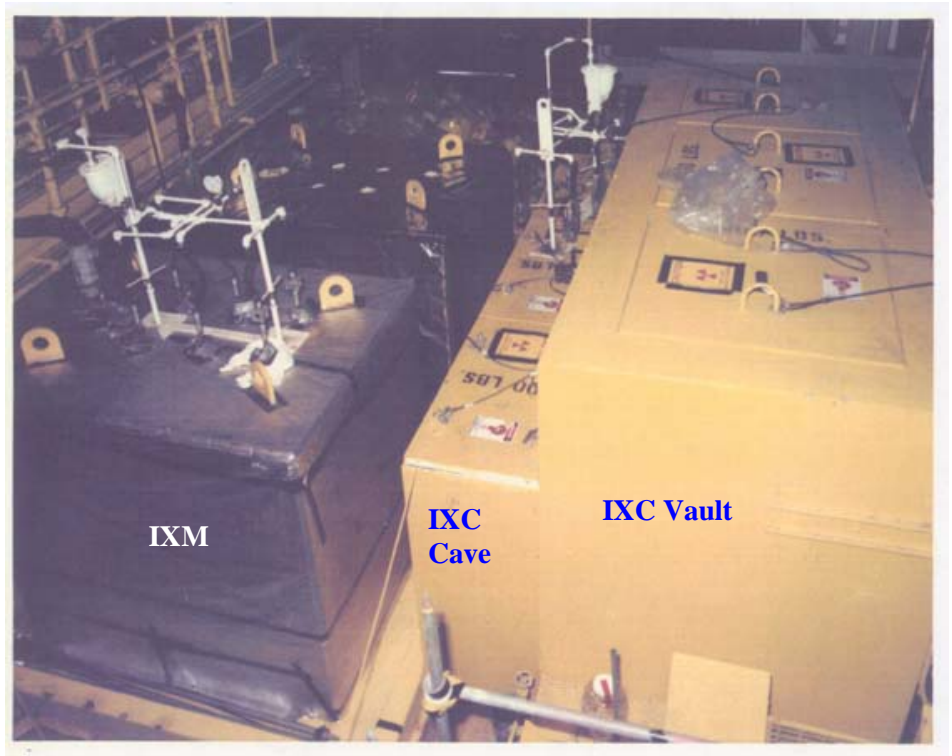

Figure 2-5. Picture of the IXC Vault and Cave 


\subsection{Hazard Analysis}

This hazard analysis supports final hazard categorization of the K East (KE) Basin Ion Exchange Columns (IXCs). It's purpose is to identify hazardous conditions associated with grouting the IXCs. Grouting of the IXCs includes grouting the IXCs in-place, storing the grouted monolith and also its removal. Although not all the details of this activity are currently defined, enough is known so that a representative set of hazardous conditions are determined. This supports identification of dispersibility factors needed for the final hazard categorization assessment. Final hazard categorization of the IXCs will support determination of the point at which the KE Basin facility may be designated a less than Hazard Category 3 (HC-3) facility (e.g., Radiological Facility).

\subsection{Summary of Preliminary Hazard Analysis}

Representative bounding hazardous conditions were identified from the Preliminary Hazard Analysis (PHA) results documented in Appendix D. The three potentially bounding hazardous conditions resulting in a radioactive release were selected and are shown in Table 2-1. Two hazardous conditions, MED-2-09 and MED-2-11 are load drop events in which the grouted monolith and IXCs are assumed to break open. In MED-2-09 the grouted monolith is dropped from a 160 ton mobile crane. In MED-2-11, the boom of a 160 ton mobile crane is falls onto the grouted monolith or an I-beam removed during demolition activities is dropped onto the grouted monolith. In the third hazardous condition a heavy vehicle such as a monolith transport carrier tractor runs into the monolith and coincidentally damages the tractor fuel tank which leads to a fire (MED-2-12). The monolith and IXCs are assumed to be cracked or broken. A fourth unique accident condition postulating an over-pressurization of an IXC due to gas generation from radiolysis of residual water (MED-2-13) was determined to not be credible (see Appendix F).

The following defines the information in Table 3-1:

- Column 1 - Unique identifier for the hazardous condition

- Column 2 - Activity during which the postulated hazardous conditions could occur based on activities 1 through 7, as defined in the original KE Basin hazard categorization assessment report SNF-22494 (Coles 2005)

- Column 3 - The material at risk

- Column 4 - The postulated hazardous condition, which is always defined as an uncontrolled release of material from a controlled location to an unwanted location

- Column 5 - A brief description of the initiating cause of the uncontrolled release

- Column 6 - A brief description of the physical consequences of the hazardous condition and an indication of how personnel are affected

- Column 7 - Accident group identifier for groups organized by like-kind accident phenomena

- FF Facility fire 
- VCF Vehicle collision and subsequent fire

- LD Load drop

- CM Cutting of the monolith

- Column 8 - The consequence category for effect on the public (maximally exposed offsite individual)

- Column 9- The consequence category for the effect on the onsite worker at $100 \mathrm{~m}$

- Column 10 - The consequence category for the effect on the facility worker.

\subsection{Overview of Hazard Analysis Sessions}

On June 10, 2005 a 4-hour session was held to establish a set of representative hazardous conditions associated with grouting the KE Basin IXCs that have the potential to result in an uncontrolled release of radioactive material. This activity includes storing the grouted IXCs and handling them during removal. The following was accomplished during the session:

- Definition of the IXC grouting activities and subsequent handling of the monolith

- Identification of the material at risk present during these activities

- Completion of a hazard identification checklist for the activity against the baseline hazard identification checklist documented in HNF-3960, K Basins Hazard Analysis (FH 2003)

- Completion of the PHA worksheets

- Screening of hazardous conditions not leading to significant radioactive material release

The results of the hazardous analysis session are documented in the following appendices/sections:

Appendix A - Session participants

Appendix B - Description of activity assessed

Section 4.1 - Material at Risk

Appendix C - Hazard Identification Checklist

Appendix D - PHA Worksheet Results 
Table 3-1. Representative Bounding Hazardous Conditions

\begin{tabular}{|c|c|c|c|c|c|c|c|c|c|c|}
\hline \multirow{2}{*}{$\begin{array}{c}\text { Hazard } \\
\text { Identification }\end{array}$} & \multirow{2}{*}{ Activity } & \multirow{2}{*}{$\begin{array}{c}\text { Material At } \\
\quad \text { Risk }\end{array}$} & \multirow[b]{2}{*}{ Hazardous Condition } & \multirow[b]{2}{*}{ Candidate Causes } & \multirow[b]{2}{*}{ Consequences } & \multirow{2}{*}{$\begin{array}{c}\text { Accident } \\
\text { Group }\end{array}$} & \multicolumn{3}{|c|}{ Consequence Category } & \multirow{2}{*}{ Remarks } \\
\hline & & & & & & & Public & $\begin{array}{c}\text { Onsite } \\
\text { Worker }\end{array}$ & \begin{tabular}{|l} 
Facility \\
Worker
\end{tabular} & \\
\hline MED-2-09 & 2 & 6 IXCs & $\begin{array}{l}\text { Release of radioactive } \\
\text { and hazardous material } \\
\text { to facility environment } \\
\text { from } 6 \text { IXCs due to } \\
\text { breaching caused by } \\
\text { dropping the grouted } \\
\text { IXC monolith. }\end{array}$ & $\begin{array}{l}\text { Human error or } \\
\text { failure of mobile } \\
\text { crane that results in } \\
\text { drop of grouted } \\
\text { IXC monolith. }\end{array}$ & $\begin{array}{l}\text { Airborne } \\
\text { particulates } \\
\text { into } \\
\text { environment. }\end{array}$ & LD & $\mathrm{L}$ & $\mathrm{L}$ & $\mathrm{N}$ & $\begin{array}{l}\text { The grouted IXC } \\
\text { monolith is } \\
\text { anticipated to be } \\
\text { lowered in-place } \\
\text { onto the transport } \\
\text { trailer and not } \\
\text { lifted. }\end{array}$ \\
\hline MED-2-11 & 2 & 6 IXCs & $\begin{array}{l}\text { Release of radioactive } \\
\text { and hazardous material } \\
\text { to facility environment } \\
\text { from } 6 \text { IXCs due to } \\
\text { breaching caused by } \\
\text { the boom of a large } \\
\text { mobile crane falling on } \\
\text { or a basin I-beam being } \\
\text { dropped on the grouted } \\
\text { IXC monolith. }\end{array}$ & $\begin{array}{l}\text { Human error or } \\
\text { mechanical failure } \\
\text { that results in drop } \\
\text { of large mobile } \\
\text { crane boom or I- } \\
\text { beam onto IXC } \\
\text { monolith. }\end{array}$ & $\begin{array}{l}\text { Airborne } \\
\text { particulates } \\
\text { into } \\
\text { environment. }\end{array}$ & LD & $\mathrm{L}$ & $\mathrm{L}$ & $\mathrm{N}$ & $\begin{array}{l}\text { Mobile crane } \\
\text { could be capable } \\
\text { of up to } 160 \text { ton } \\
\text { lift. }\end{array}$ \\
\hline MED-2-12 & 2 & $6 \mathrm{IXCs}$ & $\begin{array}{l}\text { Release of radioactive } \\
\text { and hazardous material } \\
\text { to facility environment } \\
\text { from } 6 \text { IXCs due to } \\
\text { breaching caused } \\
\text { vehicle impact and } \\
\text { subsequent fire. }\end{array}$ & $\begin{array}{l}\text { Human error or } \\
\text { mechanical failure } \\
\text { results in vehicle } \\
\text { impact (e.g. IXM } \\
\text { transport tractor) } \\
\text { into IXC monolith } \\
\text { and coincident } \\
\text { breaching of the } \\
\text { fuel tank. }\end{array}$ & $\begin{array}{l}\text { Airborne } \\
\text { particulates } \\
\text { into } \\
\text { environment. }\end{array}$ & VCF & $\mathrm{L}$ & $\mathrm{L}$ & $\mathrm{N}$ & $\begin{array}{l}\text { For vehicle } \\
\text { traveling within } \\
\text { the } 20 \text { mph speed } \\
\text { limit. }\end{array}$ \\
\hline $\mathrm{IXC}=$ & $\overline{\mathrm{n} e x c}$ & umn. & & & $\begin{array}{l}\mathrm{L}=\mathrm{lo} \\
\mathrm{M}=\mathrm{m} \\
\mathrm{Y}=\mathrm{ye} \\
\mathrm{N}=\mathrm{no}\end{array}$ & ate. & & & & \\
\hline
\end{tabular}


This page intentionally left blank. 


\subsection{Hazard Categorization Analysis}

SNF-22494, "Hazard Categorization Assessment for the K East Basin During Deactivation and Decommissioning Activities" (Coles 2005), determined the hazard categorization of the K East Basin for several proposed end Basin States. This evaluation included Basin States before and after removal of the IXCs from the basin. The evaluation showed that the K East Basin could not be down-graded to less than a Hazard Category 3 nuclear facility (e.g., a Radiological Facility) as long the as IXCs remained in the basin in their current configuration.

Subsequent to the evaluation in SNF-22494, additional information has been located and evaluated that provides an updated estimate of the total source term inventory, or material-at-risk (MAR) of the six IXCs still residing in the K East Basin. This section re-evaluates the hazard categorization of the IXCs utilizing this new source term data and the same assumptions for respirable release fraction as used in SNF-22494.

\subsection{Material-at-Risk/Inventory}

Fluor Hanford staff compiled the results of radiochemical analyses of IXC inlet and outlet water samples taken during the time period the six IXCs were in service in the basin (Green 2005). This data is summarized in Table 4-1. Sample Point 5, Cartridge Filter Outlet, was an alternate sampling point for the inlet to the IXCs. IXC Outlet Sample Points 1, 2, and 3 correspond to the outlets for the three IXCs operating in parallel at any given time which, for the six IXCs, corresponds to IXC 227, 228, and 229, respectively, and IXCs 230, 231, and 232, respectively. The six IXCs remaining in the K East Basin were operated during the following time periods:

- IXC $227-2 / 4 / 1992$ through $3 / 2 / 1992$

- IXC $228-2 / 4 / 1992$ through $2 / 27 / 1992$

- IXC $229-2 / 4 / 1992$ through $3 / 2 / 1992$

- IXC 230 - 3/6/1992 through 3/13/1992 and again from 12/14/1992 through 2/14/1993

- IXC 231 - 3/6/1992 through 3/13/1992 and again from 12/14/1992 through 2/14/1993

- IXC 232 - 3/6/1992 through 3/13/1992 and again from 12/14/1992 through 2/14/1993

The inventory of each radionuclide $\left(\mathrm{I}_{\mathrm{i}}\right)$ in each IXC is estimated from this data by first subtracting the outlet concentration from the inlet concentration and then multiplying this difference by the volume of water processed through the IXC during its service life as follows:

$$
\mathrm{I}_{\mathrm{i}}=\left(\mathrm{C}_{\mathrm{i}}-\mathrm{C}_{\mathrm{o}}\right) \times(1.0 \mathrm{E}-06 \mathrm{Ci} / \mu \mathrm{Ci}) \times \mathrm{V}_{\mathrm{R}} \times(3.785 \mathrm{l} / \mathrm{gal}) \times \mathrm{T}_{\mathrm{S}} \times(60 \mathrm{~min} / \mathrm{hr})
$$

where

$$
\begin{aligned}
& \mathrm{C}_{\mathrm{i}}=\mathrm{IXC} \text { inlet concentration }(\mu \mathrm{Ci} / \mathrm{l}) \\
& \mathrm{C}_{\mathrm{o}}=\mathrm{IXC} \text { outlet concentration }(\mu \mathrm{Ci} / \mathrm{l})
\end{aligned}
$$




$$
\begin{aligned}
& \mathrm{V}_{\mathrm{R}}=\mathrm{IXC} \text { basin water treatment rate }(\mathrm{gal} / \mathrm{min}) \\
& \mathrm{T}_{\mathrm{S}}=\text { time period IXC in service }(\mathrm{hrs})
\end{aligned}
$$

The K East Basin water treatment system operated at a process rate of $150 \mathrm{gal} / \mathrm{min}$, or a $V_{R}$ of 50 $\mathrm{gal} / \mathrm{min}$ for each of the three IXCs operating in parallel.

Since the limited water sample dates do not correspond to the exact dates that the IXCs entered and were removed from service, it is assumed for this analysis that the IXC inlet and outlet sample data for a given sample date is the efficiency of treatment for all IXC service times up to and including the nearest sample date. For example, IXC 227 had a service period of $2 / 4 / 1992$ through $3 / 2 / 1992$. Therefore, the concentration data for sample date $2 / 24 / 1992$ was used to represent the service period from 2/4/1992 to 2/25/1992 (528 hrs) and the concentration data for sample date 3/17/1992 was used to represent the service period from 2/26/1992 to 3/2/1992 (144 hrs). The Cs-137 inventory for IXC 227 was therefore calculated as follows:

$$
\begin{aligned}
\mathrm{I}_{\mathrm{i}}= & (2.11 \mathrm{E}+00 \mu \mathrm{Ci} / 1-2.23 \mathrm{E}-02 \mu \mathrm{Ci} / \mathrm{l}) \times(1.0 \mathrm{E}-06 \mathrm{Ci} / \mu \mathrm{Ci}) \times(50 \mathrm{gal} / \mathrm{min}) \times(3.785 \mathrm{l} / \mathrm{gal}) \\
& \times(528 \mathrm{hrs}) \times(60 \mathrm{~min} / \mathrm{hr})+ \\
& (3.29 \mathrm{E}+00 \mu \mathrm{Ci} / 1-3.41 \mathrm{E}-01 \mu \mathrm{Ci} / 1) \times(1.0 \mathrm{E}-06 \mathrm{Ci} / \mu \mathrm{Ci}) \times(50 \mathrm{gal} / \mathrm{min}) \times(3.785 \mathrm{l} / \mathrm{gal}) \\
& \times(144 \mathrm{hrs}) \times(60 \mathrm{~min} / \mathrm{hr}) \\
= & 17.3 \mathrm{Ci}
\end{aligned}
$$

Table 4-2 provides the similarly calculated results for the radionuclide inventories, or MAR, for each of the six IXCs.

There is no data available on Pu-241 and Am-241 concentrations in the basin water during the time periods that these IXCs were in service. This analysis therefore used the same methodology as utilized in WHC-SD-SNF-SARR-003 (WHC 1994) to develop an inventory estimate for these radionuclides. The results of mass spectrometry analyses performed on basin water samples taken in March 1993 were used to arrive at a Pu-241 to Pu-239 ratio of 13.2. The $\mathrm{Pu}-239$ inventory calculated for each IXC was multiplied by this ratio to estimate the Pu-241 inventory for each IXC. The Am-241 to Pu-239 ratio is based on center-of-basin analysis performed on water samples taken during January and February 1994. The mean of the ratio of $\mathrm{Am}-241$ to $\mathrm{Pu}-239$ for these samples is 0.45 . The Pu-239 inventory calculated for each IXC was multiplied by this ratio to estimate the Am-241 inventory for each IXC. The calculated inventories, or MAR, for Pu-241 and Am-241 for each IXC are provided in Table 4-2.

The estimated IXC radionuclide inventory presented in Table 4-2 is similar to the inventory estimated in WHC-SD-SNF-SARR-003 (WHC 1994) utilizing a more conservative methodology.

\subsection{Initial Hazard Categorization}

The initial hazard categorization is based on comparing the total radionuclide inventory quantities in the IXCs to hazard category threshold quantities defined in DOE-STD-1027-92, Hazard Categorization and Accident Analysis Techniques for Compliance with DOE Order 5480.23 Nuclear Safety Analysis Reports (DOE 1997). SNF-22494 (Coles 2005) assumed that the IXCs could be segmented for hazard categorization purposes (i.e., the IXCs were assumed to 
be removed and processed one at a time) and that each IXC could therefore be treated as a separate facility. However, in this analysis all six of the IXCs are assumed to be immobilized in a single large concrete monolith. Given this treatment and packaging configuration, it is not reasonable to segment the IXCs for hazard categorization purposes and so this analysis uses the total inventory for all six IXCs in the hazard categorization determination.

To determine the initial hazard categorization for the K East Basin (only considering the residual inventory of the IXCs), the estimated radionuclide quantity for the IXCs is compared against the Hazard Category 2 (HC-2) and HC-3 threshold quantity values (TQVs) found in DOE-STD-1027-92 (DOE 1997). The comparison involves determining the HC-2 ratios (IXC Inventory of Radionuclide $\mathrm{i} / \mathrm{TQV}$ of Radionuclide i) of all the radionuclide quantities. These ratios are summed and the result is compared to 1.0. If the result is less than one, then the facility is not HC-2 $(<\mathrm{HC}-2)$. If greater than 1.0, the facility is initially HC-2. Similarly, the $\mathrm{HC}-3$ ratios (IXC Inventory of Radionuclide $\mathrm{i} / \mathrm{TQV}$ of Radionuclide i) of all the radionuclide quantities to the category threshold quantities are summed and the result is compared to 1.0. The results for both $\mathrm{HC}-2$ and $\mathrm{HC}-3$ are presented in Table 4-3. The HC-3 ratio greater than 1.0 (11.7) combined the with $\mathrm{HC}-2$ ratio being less than $1.0(0.072)$ indicates that the IXCs are initially $\mathrm{HC}-3$.

\subsection{Hazard Categorization Utilizing Adjusted TQVs}

SNF-22494 (Coles 2005) developed adjusted TQVs consistent with the interpretation provided by the DOE Office of Nuclear Safety Policy and Standards in NSTP 2002-2 (DOE 2002) for the use of facility specific accident analysis for final hazard categorization.

Adjustment of the DOE-STD-1027-92 TQVs was performed based on the differences between certain inputs used in the original underlying Environmental Protection Agency (EPA) calculations and those corresponding to bounding unmitigated accidents identified for K East Basin D\&D activities. The factors considered were airborne release fraction (ARF), respirable fraction (RF), and damage ratio (DR). Accordingly, the DOE-STD-1027-92 TQVs were adjusted by the ratio of the bounding case ARF, RF, and DRs over those used in the original EPA calculations.

This analysis utilizes this same methodology to develop adjusted TQVs for the IXCs, which are in turn utilized to calculate an adjusted HC-3 ratio. From Section 3, the credible accident scenarios that must be considered under unmitigated conditions are 1) drop of the grouted IXC monolith, 2) dropping of an I-beam or falling crane boom onto the grouted IXC monolith, and 3) vehicle collision with the grouted IXC monolith and subsequent fire. Overpressurization of the grouted IXCs was determined to not be credible as long as the grout/concrete used to encapsulate the IXCs does not contain aggregrate that could potentially plug the IXC filter (see Appendix F). Hydrogen deflagration/detonation is not credible since there is no ignition source. Each of the three identified bounding accident scenarios is evaluated in turn.

\subsubsection{Drop of Grouted IXC Monolith}

SNF-22494 (Coles 2005) identified an appropriate ARF and RF from DOE-HDBK-301094 (DOE 2000) for use in drop accidents. The ARF and RF selected was 1.0E-03 and 0.1, respectively, for a product ARF x RF of 1.0E-04. Also from SNF-22494, the ARF x RF utilized in the EPA calculations to develop the HC-3 TQVs was 1.0E-02 for Sr-90 and Cs-137 and 1.0E- 
03 for Pu-238, Pu-239, Pu-241, and Am-241. The adjusted TQV (TQV $\left.{ }_{\text {new }}\right)$ is calculated as follows:

$$
\mathrm{TQV}_{\text {new }}=\mathrm{TQV} /\{(\text { Accident-specific ARF } \mathrm{x} \mathrm{RF}) /(\text { EPA model ARF } \times \mathrm{RF})\}
$$

The calculated $T Q V_{\text {new }}$ for each radionuclide is provided in Table 4-4. The new HC-3 ratios (Inventory of Radionuclide $\mathrm{i} / \mathrm{TQV}_{\text {new }}$ of Radionuclide $\mathrm{i}$ ) are also provided in Table $4-4$. The sum of the HC-3 ratios is less than $1.0(0.77)$ indicating that for this postulated accident the six grouted IXCs are less than Hazard Category 3.

\subsubsection{Impact of Falling Crane Boom or I-Beam}

This postulated accident is the same as the postulated drop accident from an accident/consequence analysis perspective. The analysis and results in Section 4.3.1 therefore apply to this postulated accident. From Table 4-4, the sum of the HC-3 ratios is less than 1.0 (0.77) indicating that for this postulated accident the six grouted IXCs is less than Hazard Category 3.

\subsubsection{Vehicle Collision and Subsequent Fire}

SNF-22494 (Coles 2005) identified an appropriate ARF and RF from DOE-HDBK-301094 (DOE 2000) for use in fire accidents. The ARF and RF selected was 2.5E-03 and 1.0, respectively, for a product ARF $x$ RF of 2.5E-03. This ARF and RF, however, are for cesium and strontium release from burning of organic liquid (kerosene). DOE-HDBK-3010-94 (Section 7.3.6.2) suggests use of a combined ARF $x$ RF of $1.0 \mathrm{E}-02$ for the combustion of polystyrene ion exchange resin contaminated with uranium, which is more applicable for this analysis. The $1.0 \mathrm{E}-02$ value is the "worst" case result of the combustion tests documented in DOE-HDBK3010-94 (the other tests yielded ARF x RF values ranging from 1.6E-03 to 1.8E-03). While apparently conservative based on the available test results, this analysis will use the recommended value of $1.0 \mathrm{E}-02$ for ARF $x$ RF for the combustion of ion exchange resin. From SNF-22494, the ARF x RF utilized in the EPA calculations to develop the HC-3 TQVs was 1.0E-02 for Sr-90 and Cs-137 and 1.0E-03 for Pu-238, Pu-239, Pu-241, and Am-241. From Section 4.3.1, the adjusted TQV (TQV $\mathrm{Tew}_{\text {) }}$ ) is calculated as follows:

$$
\mathrm{TQV}_{\text {new }}=\mathrm{TQV} /\{(\text { Accident-specific ARF } \mathrm{x} \mathrm{RF}) /(\text { EPA model ARF } \times \mathrm{RF})\}
$$

The calculated $T Q V_{\text {new }}$ for each radionuclide is provided in Table 4-5. The new HC-3 ratios (Inventory of Radionuclide $\mathrm{i} / \mathrm{TQV}_{\text {new }}$ of Radionuclide i) are also provided in Table 4-5. The sum of the HC-3 ratios is greater than 1.0 (77.0) indicating that for this postulated accident the six grouted IXCs are Hazard Category 3. Based on this result, downgrade of the K East Basin to less that Hazard Category 3 will require that the grouted IXC monolith be sufficiently robust structurally not to fail in a postulated vehicle collision and subsequent fire. 
Table 4-1. IXC Inlet and Outlet Water Sample Data

\begin{tabular}{|c|c|c|c|c|c|c|}
\hline $\begin{array}{l}\text { Sample } \\
\text { Date }\end{array}$ & Radionuclide & $\begin{array}{l}\text { Sample } \\
\text { Point 9- } \\
\text { IXC Inlet } \\
(\mu \mathrm{C} / \mathrm{l})\end{array}$ & $\begin{array}{l}\text { Sample } \\
\text { Point 5 - } \\
\text { Cartridge } \\
\text { Filter } \\
\text { Outlet } \\
(\mu \mathrm{Ci} / \mathrm{l})\end{array}$ & $\begin{array}{l}\text { Sample } \\
\text { Point 1 - } \\
\text { IXC } \\
\text { Outlet } \\
(\mu \mathrm{Ci} / \mathrm{l})\end{array}$ & $\begin{array}{l}\text { Sample } \\
\text { Point 2- } \\
\text { IXC } \\
\text { Outlet } \\
(\mu \mathrm{Ci} / \mathrm{l})\end{array}$ & $\begin{array}{l}\text { Sample } \\
\text { Point } 3 \text { - } \\
\text { IXC } \\
\text { Outlet } \\
(\mu \mathrm{Ci} / \mathrm{l})\end{array}$ \\
\hline \multirow[t]{4}{*}{$2 / 25 / 1992$} & $\mathrm{Pu}-238$ & & $2.68 \mathrm{E}-03$ & $1.16 \mathrm{E}-03$ & $1.00 \mathrm{E}-03$ & $1.00 \mathrm{E}-03$ \\
\hline & $\mathrm{Pu}-239$ & & $1.58 \mathrm{E}-02$ & 7.16E-03 & $2.00 \mathrm{E}-03$ & $3.01 \mathrm{E}-03$ \\
\hline & Cs-137 & $2.11 \mathrm{E}+00$ & & $2.23 \mathrm{E}-02$ & $2.52 \mathrm{E}-02$ & $3.32 \mathrm{E}-02$ \\
\hline & Sr-90 & & $1.32 \mathrm{E}+00$ & 4.92E-02 & $2.15 \mathrm{E}-01$ & $1.12 \mathrm{E}-01$ \\
\hline \multirow[t]{4}{*}{$3 / 17 / 1992$} & $\mathrm{Pu}-238$ & & $1.09 \mathrm{E}-03$ & $6.26 \mathrm{E}-04$ & $5.00 \mathrm{E}-04$ & $3.30 \mathrm{E}-04$ \\
\hline & $\mathrm{Pu}-239$ & & 7.83E-03 & $4.00 \mathrm{E}-03$ & $2.76 \mathrm{E}-03$ & $1.97 \mathrm{E}-03$ \\
\hline & Cs-137 & $3.29 \mathrm{E}+00$ & & $3.41 \mathrm{E}-01$ & $1.04 \mathrm{E}-02$ & $5.82 \mathrm{E}-01$ \\
\hline & Sr-90 & & $9.54 \mathrm{E}-01$ & $6.47 \mathrm{E}-02$ & $1.77 \mathrm{E}-01$ & $1.00 \mathrm{E}-01$ \\
\hline \multirow[t]{4}{*}{$12 / 29 / 1992$} & $\mathrm{Pu}-238$ & $1.16 \mathrm{E}-02$ & & $4.57 \mathrm{E}-03$ & $2.51 \mathrm{E}-03$ & $1.95 \mathrm{E}-03$ \\
\hline & $\mathrm{Pu}-239$ & $6.40 \mathrm{E}-02$ & & $1.85 \mathrm{E}-02$ & $1.21 \mathrm{E}-02$ & $1.01 \mathrm{E}-02$ \\
\hline & Cs-137 & $1.63 \mathrm{E}+00$ & & $1.19 \mathrm{E}+00$ & $6.82 \mathrm{E}-01$ & $1.01 \mathrm{E}+00$ \\
\hline & Sr-90 & $1.17 \mathrm{E}+00$ & & $1.58 \mathrm{E}-01$ & $9.71 \mathrm{E}-02$ & 4.40E- 01 \\
\hline \multirow[t]{4}{*}{$1 / 26 / 1993$} & $\mathrm{Pu}-238$ & $1.19 \mathrm{E}-02$ & & $6.04 \mathrm{E}-03$ & $1.04 \mathrm{E}-02$ & $2.53 \mathrm{E}-03$ \\
\hline & $\mathrm{Pu}-239$ & $6.52 \mathrm{E}-02$ & & $2.74 \mathrm{E}-02$ & 5.45E-02 & $1.24 \mathrm{E}-02$ \\
\hline & Cs-137 & $2.62 \mathrm{E}+00$ & & $1.73 \mathrm{E}-01$ & $1.10 \mathrm{E}+00$ & $1.47 \mathrm{E}-01$ \\
\hline & Sr-90 & 7.44E-01 & & $7.39 \mathrm{E}-02$ & $3.83 \mathrm{E}-01$ & $1.25 \mathrm{E}-01$ \\
\hline \multirow[t]{4}{*}{ 2/4/1993 } & $\mathrm{Pu}-238$ & $1.51 \mathrm{E}-02$ & & $2.93 \mathrm{E}-03$ & 2.34E-02 & $1.49 \mathrm{E}-03$ \\
\hline & $\mathrm{Pu}-239$ & $8.87 \mathrm{E}-02$ & & $6.64 \mathrm{E}-03$ & $1.32 \mathrm{E}-02$ & $9.81 \mathrm{E}-03$ \\
\hline & Cs-137 & $2.35 \mathrm{E}+00$ & & 3.49E-01 & $1.34 \mathrm{E}+00$ & $1.34 \mathrm{E}-01$ \\
\hline & Sr-90 & 7.01E-01 & & $1.81 \mathrm{E}-02$ & 3.37E-02 & $5.48 \mathrm{E}-03$ \\
\hline
\end{tabular}




\begin{tabular}{|l|c|c|c|c|c|c|c|}
\hline \multicolumn{7}{|c|}{ Table 4-2. IXC Radionuclide Inventory } \\
\hline \multirow{2}{*}{ Radionuclide } & \multicolumn{7}{|c|}{ Inventory (Ci) } \\
\cline { 2 - 9 } & IXC 227 & IXC 228 & IXC 229 & IXC 230 & IXC 231 & IXC 232 & Total \\
\hline Sr-90 & $8.83 \mathrm{E}+00$ & $7.05 \mathrm{E}+00$ & $8.41 \mathrm{E}+00$ & $1.29 \mathrm{E}+01$ & $1.06 \mathrm{E}+01$ & $1.12 \mathrm{E}+01$ & $5.90 \mathrm{E}+01$ \\
\hline Cs-137 & $1.65 \mathrm{E}+01$ & $1.43 \mathrm{E}+01$ & $1.61 \mathrm{E}+01$ & $3.11 \mathrm{E}+01$ & $2.45 \mathrm{E}+01$ & $3.22 \mathrm{E}+01$ & $1.35 \mathrm{E}+02$ \\
\hline Pu-238 & $9.75 \mathrm{E}-03$ & $1.04 \mathrm{E}-02$ & $1.11 \mathrm{E}-02$ & $1.06 \mathrm{E}-01$ & $3.18 \mathrm{E}-02$ & $1.48 \mathrm{E}-01$ & $3.18 \mathrm{E}-01$ \\
\hline Pu-239 & $5.70 \mathrm{E}-02$ & $8.55 \mathrm{E}-02$ & $8.47 \mathrm{E}-02$ & $6.95 \mathrm{E}-01$ & $5.03 \mathrm{E}-01$ & $8.43 \mathrm{E}-01$ & $2.27 \mathrm{E}+00$ \\
\hline Pu-241 & $7.53 \mathrm{E}-01$ & $1.13 \mathrm{E}+00$ & $1.12 \mathrm{E}+00$ & $9.18 \mathrm{E}+00$ & $6.64 \mathrm{E}+00$ & $1.11 \mathrm{E}+01$ & $2.99 \mathrm{E}+01$ \\
\hline Am-241 & $2.57 \mathrm{E}-02$ & $3.85 \mathrm{E}-02$ & $3.81 \mathrm{E}-02$ & $3.13 \mathrm{E}-01$ & $2.26 \mathrm{E}-01$ & $3.79 \mathrm{E}-01$ & $1.02 \mathrm{E}+00$ \\
\hline
\end{tabular}

Table 4-3. Initial Hazard Categorization Based on IXC Radionuclide Inventory

\begin{tabular}{|l|c|c|c|c|c|}
\hline Radionuclide & $\begin{array}{c}\text { Total IXC } \\
\text { Inventory (Ci) }\end{array}$ & $\begin{array}{c}\text { HC-2 TQV } \\
\text { (Ci) }\end{array}$ & $\begin{array}{c}\text { HC-2 } \\
\text { Ratio }\end{array}$ & $\begin{array}{c}\text { HC-3 TQV } \\
\text { (Ci) }\end{array}$ & $\begin{array}{c}\text { HC-3 } \\
\text { Ratio }\end{array}$ \\
\hline Sr-90 & $4.47 \mathrm{E}+01$ & $2.20 \mathrm{E}+04$ & $2.03 \mathrm{E}-03$ & $1.60 \mathrm{E}+01$ & $2.79 \mathrm{E}+00$ \\
\hline Cs-137 & $1.02 \mathrm{E}+02$ & $8.90 \mathrm{E}+04$ & $1.15 \mathrm{E}-03$ & $6.00 \mathrm{E}+01$ & $1.70 \mathrm{E}+00$ \\
\hline Pu-238 & $2.88 \mathrm{E}-01$ & $6.20 \mathrm{E}+01$ & $4.65 \mathrm{E}-03$ & $6.20 \mathrm{E}-01$ & $4.65 \mathrm{E}-01$ \\
\hline Pu-239 & $2.27 \mathrm{E}+00$ & $5.60 \mathrm{E}+01$ & $4.05 \mathrm{E}-02$ & $5.20 \mathrm{E}-01$ & $4.36 \mathrm{E}+00$ \\
\hline Pu-241 & $1.59 \mathrm{E}+01$ & $2.90 \mathrm{E}+03$ & $5.50 \mathrm{E}-03$ & $3.20 \mathrm{E}+01$ & $4.98 \mathrm{E}-01$ \\
\hline Am-241 & $1.00 \mathrm{E}+00$ & $5.50 \mathrm{E}+01$ & $1.82 \mathrm{E}-02$ & $5.20 \mathrm{E}-01$ & $1.93 \mathrm{E}+00$ \\
\hline Sum & $1.66 \mathrm{E}+02$ & & $7.20 \mathrm{E}-02$ & & $1.17 \mathrm{E}+01$ \\
\hline
\end{tabular}

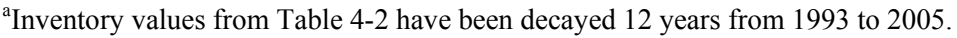


Table 4-4. Final Hazard Categorization for Grouted IXC Drop Accident

\begin{tabular}{|l|c|c|c|c|c|}
\hline Radionuclide & $\begin{array}{c}\text { Total IXC } \\
\text { Inventory } \\
\text { (Ci) }^{\mathbf{a}}\end{array}$ & $\begin{array}{c}\text { EPA Model } \\
\text { ARF x RF }\end{array}$ & $\begin{array}{c}\text { Accident- } \\
\text { Specific } \\
\text { ARF x RF }\end{array}$ & $\begin{array}{c}\text { HC-3 } \\
\text { TQV }_{\text {new }} \text { (Ci) }\end{array}$ & $\begin{array}{c}\text { HC-3 } \\
\text { Ratio }\end{array}$ \\
\hline Sr-90 & $4.47 \mathrm{E}+01$ & $1.0 \mathrm{E}-02$ & $1.0 \mathrm{E}-04$ & $1.60 \mathrm{E}+03$ & $2.79 \mathrm{E}-02$ \\
\hline $\mathrm{Cs}-137$ & $1.02 \mathrm{E}+02$ & $1.0 \mathrm{E}-02$ & $1.0 \mathrm{E}-04$ & $6.00 \mathrm{E}+03$ & $1.70 \mathrm{E}-02$ \\
\hline Pu-238 & $2.88 \mathrm{E}-01$ & $1.0 \mathrm{E}-03$ & $1.0 \mathrm{E}-04$ & $6.20 \mathrm{E}+00$ & $4.65 \mathrm{E}-02$ \\
\hline Pu-239 & $2.27 \mathrm{E}+00$ & $1.0 \mathrm{E}-03$ & $1.0 \mathrm{E}-04$ & $5.20 \mathrm{E}+00$ & $4.36 \mathrm{E}-01$ \\
\hline Pu-241 & $1.59 \mathrm{E}+01$ & $1.0 \mathrm{E}-03$ & $1.0 \mathrm{E}-04$ & $3.20 \mathrm{E}+02$ & $4.98 \mathrm{E}-02$ \\
\hline Am-241 & $1.00 \mathrm{E}+00$ & $1.0 \mathrm{E}-03$ & $1.0 \mathrm{E}-04$ & $5.20 \mathrm{E}+00$ & $1.93 \mathrm{E}-01$ \\
\hline Sum & $1.66 \mathrm{E}+02$ & & & & $7.70 \mathrm{E}-01$ \\
\hline
\end{tabular}

a Inventory values from Table 4-2 have been decayed 12 years from 1993 to 2005.

Table 4-5. Final Hazard Categorization for Vehicle Collision and Subsequent Fire Accident

\begin{tabular}{|l|c|c|c|c|c|}
\hline Radionuclide & $\begin{array}{c}\text { Total IXC } \\
\text { Inventory } \\
(\mathbf{C i})^{\mathbf{a}}\end{array}$ & $\begin{array}{c}\text { EPA Model } \\
\text { ARF x RF }\end{array}$ & $\begin{array}{c}\text { Accident- } \\
\text { Specific } \\
\text { ARF x RF }\end{array}$ & $\begin{array}{c}\text { HC-3 } \\
\text { TQV }_{\text {new }} \text { (Ci) }\end{array}$ & $\begin{array}{c}\text { HC-3 } \\
\text { Ratio }\end{array}$ \\
\hline Sr-90 & $4.47 \mathrm{E}+01$ & $1.0 \mathrm{E}-02$ & $1.0 \mathrm{E}-02$ & $1.60 \mathrm{E}+01$ & $2.79 \mathrm{E}+00$ \\
\hline $\mathrm{Cs}-137$ & $1.02 \mathrm{E}+02$ & $1.0 \mathrm{E}-02$ & $1.0 \mathrm{E}-02$ & $6.00 \mathrm{E}+01$ & $1.70 \mathrm{E}+00$ \\
\hline Pu-238 & $2.88 \mathrm{E}-01$ & $1.0 \mathrm{E}-03$ & $1.0 \mathrm{E}-02$ & $6.20 \mathrm{E}-02$ & $4.65 \mathrm{E}+00$ \\
\hline Pu-239 & $2.27 \mathrm{E}+00$ & $1.0 \mathrm{E}-03$ & $1.0 \mathrm{E}-02$ & $5.20 \mathrm{E}-02$ & $4.36 \mathrm{E}+01$ \\
\hline Pu-241 & $1.59 \mathrm{E}+01$ & $1.0 \mathrm{E}-03$ & $1.0 \mathrm{E}-02$ & $3.20 \mathrm{E}+00$ & $4.98 \mathrm{E}+00$ \\
\hline Am-241 & $1.00 \mathrm{E}+00$ & $1.0 \mathrm{E}-03$ & $1.0 \mathrm{E}-02$ & $5.20 \mathrm{E}-02$ & $1.93 \mathrm{E}+01$ \\
\hline Sum & $1.66 \mathrm{E}+02$ & & & & $7.70 \mathrm{E}+01$ \\
\hline
\end{tabular}

a Inventory values from Table 4-2 have been decayed 12 years from 1993 to 2005. 
This page intentionally left blank 


\subsection{Grouted IXC Monolith Structural Assessment}

PNNL performed a structural assessment of the IXC grouted monolith based on preconceptual design information provided by the $\mathrm{K}$ Basin Closure Project. The intent of this analysis is to provide input into the design of the monolith based on a structural assessment of the potential forces being imposed on the monolith from the postulated accident scenarios identified in Section 3. The structural assessment provided in this section utilizes engineering judgment and comparisons with engineering analogs to develop conclusions and recommended monolith design inputs to prevent failure (breach/rupture) of the grouted IXCs.

\subsection{IXC Monolith Conceptual Design}

The design of the existing K East Basin IXC Vault and attached IXC Cave is assumed to be accurately depicted by engineering drawings H-1-34837 and H-1-34838. There are three cavities in the concrete vault with each containing a single IXC, each of which are covered by a large removable concrete plug. In addition, there is a temporary storage cave beside the concrete structure. This cave is framed with 2 inch angle steel and is approximately 30 inches wide, by 8 feet tall, by 15 feet long and has $1 / 2$ inch thick lead blankets suspended from the angle frame. The lead blankets surround the perimeter and cover the top of the cave, and are hung as partitions between the outside perimeter wall and the concrete block to form individual cells. There are six cells framed this way, three of which contain IXCs.

The initial analysis of this existing structure was done with the understanding that there would be the following alterations made to the existing structure. First the three vaults in the existing concrete block would be filled around the ion exchange columns with either concrete or a grout. Then a 12 inch concrete over-pour would be made. The top and exposed sides of the concrete block would receive the additional concrete. The temporary storage cave would be surrounded with new forms 12 inches out from the existing angle structure and all of this including around the three IXCs would be filled with concrete. This would result in a monolith weighing approximately 150 tons (300,000 pounds).

For the purposes of the evaluation, it was assumed that the bond between the existing structure and the new concrete would be full strength and no shearing would occur on the bond line if the structure is subjected to loading. The original prints indicate \#5 rebar located in the original pour located on 12 inch centers in both the longitudinal and transverse directions at 12 inch height increments. This amount of rebar is present to hold the concrete together in the event of cracks, not as a significant source of reinforced strength. In this case, it means that the steel must be ignored as a reinforcing strength factor. Even if the new 12 inches of additional material were to be reinforced, the amount of material below the neutral axis would be insufficient to provide increased load capacity. The new concrete would be reinforced in the same manner as the existing structure.

After the analysis was reviewed, it was determined that some of the assumptions and information required reevaluation. Specifically, the 12-inch thick concrete over-pour was intended to be for the final monolith for eventual disposal and not necessarily the interim monolith for hazard categorization purposes. A revised set of conditions was imposed and the 
analysis was updated. The primary change was the deletion of the 12 inch over-pour around the existing concrete vault and temporary storage cave. Instead, the existing concrete block would only have the vault holes containing the IXCs filled with concrete/grout. The temporary storage cave does not have sufficient clearance for an additional 12 inches of concrete, so the concept is to form around the existing 2 inch angle structure and fill the temporary storage cave with concrete. This would essentially have the outside wall of this structure be the $1 / 2$ inch lead curtains. The estimated weight of the total monolith based on concrete weighing 4,000 lb/cubic yard is 188,000 pounds or 94 tons. The updated analysis reflects this conceptual monolith.

\subsection{Monolith Drop Accident}

Recall that the conclusion of the hazard categorization analysis in Section 4.3 was that, for the postulated monolith drop accident, the six grouted IXCs are less than Hazard Category 3 based on the use of modified TQVs assuming an accident-specific ARF and RF. However, the K East Basin contains source terms in locations other than just the six IXCs that contribute to its overall hazard categorization. Given this fact in combination with the results of this analysis that the sum of the HC-3 ratios for the IXC monolith is only slightly less than $1.0(0.77)$, it is unlikely that using accident-specific ARFs and RFs only will support a downgrade of the basin to less that Hazard Category 3. Based on this conclusion, downgrade of the K East Basin to less that Hazard Category 3 will likely require that the grouted IXC monolith be sufficiently robust structurally to not fail from a drop accident. A structural assessment was performed to develop design specification to make the grouted monolith sufficiently robust structurally to prevent a release of contaminated material from this postulated accident. The following assumptions are made to evaluate the stresses on the IXCs due to a monolith drop accident:

IXC weights $800 \mathrm{lbs}, \mathrm{W}$

IXC is 24 inches in diameter, D

IXC has a $1 / 4$ inch wall thickness, $t$

IXC is made of steel with a yield strength of $30,000 \mathrm{psi}, \sigma_{\mathrm{y}}$

The IXC is encased in grout and is oriented vertically

The monolith is dropped from a maximum height of 10 feet, $\mathrm{h}$

The force required to plastically yield (deform) the wall of the IXC around its circumference due to an axial acceleration load is calculated as follows:

Area $=\pi \mathrm{Dt}=3.14 *\left((24 \mathrm{in} / 2)^{2} *-(23.5 \mathrm{in} / 2)^{2}\right)=18.7 \mathrm{in}^{2}$

Yield force $=$ Area times yield strength $=18.7 \mathrm{in}^{2} * 30,000 \mathrm{psi}=561,000 \mathrm{lbs}$

Required g level $=561,000 \mathrm{lbs} / 800 \mathrm{lbs}=793 \mathrm{~g}$ 's

Stop depth for required g level for 10 foot drop $=120$ inches/793 $=0.15$ inch

Even if the block were to be dropped on an unyielding surface, the bottom of the block would be crumbled some amount. It is unrealistic to expect an IXC to experience any deformation during a monolith drop from ten feet. If the monolith were dropped at an orientation other than bottom down, there could be lateral components to the acceleration loads. 
For a grouted IXC or an IXC with other fill inside the cavity, these loading conditions would be less severe.

Based on this assessment, a drop of the monolith from ten feet does not present a significant risk of IXC rupture. The monolith will act as a large mass dampener.

\subsection{Boom Drop/I Beam Drop Accident}

The conclusion of the hazard categorization analysis in Section 4.3 was that, for the postulated drop of a crane boom/I beam onto the monolith, the six grouted IXCs are less than Hazard Category 3 based on the use of accident-specific ARFs and RFs. However, the K East Basin contains source terms in locations other than just the six IXCs that contribute to its overall hazard categorization. Given this fact in combination with the results of this analysis that the sum of the HC-3 ratios for the IXC monolith is only slightly less than $1.0(0.77)$, it is unlikely that using accident-specific ARFs and RFs only will support a downgrade of the basin to less that Hazard Category 3. Based on this conclusion, downgrade of the $\mathrm{K}$ East Basin to less that Hazard Category 3 will likely require that the grouted IXC monolith be sufficiently robust structurally to not fail from the impact of a falling object accident. A structural assessment was performed to develop design specification to make the grouted monolith sufficiently robust structurally to prevent a release of contaminated material from this postulated accident.

One potential accident condition is an object falling onto the top of the concrete during $\mathrm{K}$ East Basin demolition activities. The top of the monolith is the most vulnerable face for such an impact due to the thinner concrete. There are two worst case scenarios to consider. The first is a large heavy beam falling across the top of the monolith and the second is a heavy beam being dropped and falling end-on onto the top of the monolith.

For the first case, the issue is two-fold: 1) the strength of the block under this impulse bending moment and 2) the impact of the beam on the surface of the block and the ensuing damage. For the bending moment the supplied drawings of the structure were examined. This basically gives a monolith of $15^{\prime} \mathrm{L} \times 6^{\prime} \mathrm{W} \times 11^{\prime} \mathrm{H}$. Examination of the original prints reveals that the concrete was reinforced with minimal rebar, at 5 or 6 in the longitudinal dimension for a stress area of about 2 square inches or a load bearing capability in tension of roughly 2" x 40,000 $\mathrm{lb}($ yield $)=80,000$ pounds. While there is additional rebar moving up from the bottom of the monolith, it is at one foot intervals and is ever closer to the neutral axis of the monolith. Assuming a nominal strength of 2500 PSI of compressive strength for the concrete this provides a compressive strength of $\sim 32,400,000$ pounds, totally overwhelming the steel reinforcement tension component. Additionally, since concrete has virtually no tensile strength, a conservative approach is to not use the lower half of the block for strength considerations. Thus taking a distance from the neutral axis, see Figure 5-1, of 65 ” x 32,400,000 lb =2,106,000,000 in-lb or $175,500,000 \mathrm{ft}-\mathrm{lb}$. Thus the load capacity of the monolith is sufficient for any foreseen event. With loads of this magnitude, the basic strength of the floor into which this monolith is attached may be an issue before the monolith fails.

The second consideration is for a dropped beam falling end-on onto the monolith. While the normal compressive strength used for concrete calculations varies from $2500-3000$ PSI, assuming 2500 is conservative. If a beam were to be dropped from virtually any height, end on, the force would exceed the compressive strength of the concrete and some level of penetration would occur in addition to the force moment applied to the structure. If the bending strength of 
the monolith is assumed to be sufficient to handle the load, the main issue becomes the case of the beam penetrating far enough into the monolith to penetrate into the IXC.

While no information was available on the specific design and weight of beams that could be dropped on the monolith during demolition activities, this analysis assumed a relatively large $\mathrm{W}$-shape steel beam having the following properties:

W12-336, 12 inch beam, $336 \mathrm{lb} / \mathrm{ft}$, end area $=98.8$ inches $^{2}$, perimeter length $=90$ inches

Beam length 20 feet, weight $=6720$ pounds $=6720 \mathrm{lbs} / 32.2 \mathrm{ft} / \mathrm{sec}^{2}=208 \mathrm{slugs}$

Drop distance $=20$ feet

Velocity at impact $(\mathrm{v})=$ at where $\mathrm{a}=32.2 \mathrm{ft} / \mathrm{sec}^{2}$ and $\mathrm{t}=$ drop time

$20 \mathrm{ft}=1 / 2\left(32.2 \mathrm{ft} / \mathrm{sec}^{2}\right) \mathrm{t}^{2} \quad \mathrm{t}^{2}=40 \mathrm{ft} / 32.2 \mathrm{ft} / \mathrm{sec}^{2} \mathrm{t}=1.11 \mathrm{sec}$

$\mathrm{V}=\mathrm{at}=\left(32.2 \mathrm{ft} / \mathrm{sec}^{2}\right)(1.11 \mathrm{sec})=35.74 \mathrm{ft} / \mathrm{sec}$

Kinetic Energy $=1 / 2 \mathrm{mv}^{2}=1 / 2(208$ slugs $)(35.74 \mathrm{ft} / \mathrm{sec})^{2}=132,860 \mathrm{lb}-\mathrm{ft}$

To punch out an area of steel equal to the perimeter length of the beam assume a diameter of 25.8 inches. The shear strength of steel is $0.75 \times$ (ultimate strength $=100,000$ ) or 75,000 psi, yielding a shear force of:

75,000 psi x 90 inches $\times 0.5$ inch $=3,375,000$ pounds

Shearing the 0.5 inch thick plate ( $1 / 24$ of a foot) gives a value of $1 / 24$ of $3,375,000$ or 140,625 lb-ft.

Thus a $140,625 \mathrm{lb}-\mathrm{ft} / 132,860 \mathrm{lb}-\mathrm{ft}=1.05$ safety margin exists for a 0.5 -inch thick steel plate assuming a relatively large beam falls end-on onto the plate. This result is conservative since for the monolith the steel plate is supported by the concrete below it which prevents shearing as it accepts the load from the steel and distributes it through the concrete. We conclude that the $1 / 2$ inch steel plate backed up by the concrete vault will provide a satisfactory safety factor for this load drop for the beam size evaluated.

\subsection{Vehicle Impact and Subsequent Fire Accident}

The hazard categorization analysis in Section 4.3 for the vehicle impact and subsequent fire concluded that a downgrade of the six grouted IXCs to less than Hazard Category 3 would not be possible using only accident-specific ARFs and RFs. This section assesses the structural and fire integrity of the grouted monolith to determine how it will protect the IXCs from the energy and forces imposed by a postulated impacting vehicle and subsequent fire.

\subsubsection{Structural Assessment of Vehicle Impact}

While they are of different designs and have different functions, there is some insight on the durability of the concrete monolith due to vehicle impacts that can be gained from the performance of the traffic barriers known as Jersey Barriers. Jersey Barriers are designed to restrain vehicle impacts but primarily for a glancing impact. Jersey Barriers are intended to prevent cars from going off bridge sides or into other traffic lanes while doing the least amount of life threatening damage to the people in the vehicles. They are designed to interface with the crumpling of the car/truck while reducing the chances for overturning. 
The concrete vault being evaluated for vehicle impact is much different. It is greatly larger (188,000 vs. 3900 pounds) and of a much different shape. However, it is made of concrete and has steel rebar. The size and placement of the rebar in the existing vault appears to be mostly for holding the pieces together if/when the concrete cracks. Since the vault is a large, rigid, and massive structure compared to a vehicle, one would expect the deformation of the vehicle to absorb most of the impact energy. Energy absorption by the vault will be primarily crushing of the concrete. Even if substantial fracturing of the concrete were to occur, the rebar in the concrete does supply a measure of deformation restraint. When the size of the concrete vault and the amount of rebar are compared to the typical Jersey Barrier, with the weight of a barrier at roughly $2 \%$ of the vault, the collision force absorbed by the vault will go into some level of concrete degradation and the rest into trying to move the huge mass. This analogue suggests that a vehicle impact is a non-issue for the existing concrete vault.

Furthermore, the force imposed by the weight of a fully loaded tractor and single trailer at 81,000 pounds moving at a velocity of $29.4 \mathrm{feet} / \mathrm{second}(20 \mathrm{mph})$, and assuming the vehicle will crush one foot on impact, is calculated as follows:

$$
\begin{aligned}
& \text { Weight }=81,000 \mathrm{lbs}=81,000 \mathrm{lbs} / 32.2 \mathrm{lbs} / \mathrm{slug}=2516 \mathrm{slugs} \\
& \text { Speed }=29.4 \mathrm{ft} / \mathrm{s}=20 \mathrm{mi} / \mathrm{hr} \\
& \text { Crush Distance }=1 \mathrm{ft} \\
& \text { Kinetic Energy }=1 / 2 \mathrm{mv}^{2}=1 / 2(2516 \mathrm{slugs})(29.4 \mathrm{ft} / \mathrm{s} \mathrm{x} 29.4 \mathrm{ft} / \mathrm{s}) / 1 \mathrm{ft}=1,087,000 \mathrm{lbf}
\end{aligned}
$$

The mean force acting between the truck and vault during this impact would be approximately 1,100,000 pounds and the impact would take a little more than an eighth of a second. With a compressive strength of approximately 2500 psi, only 435 square inches $(\sim 21$ inches $\mathrm{x} 21$ inches) of concrete surface would be required to resist the 1,100,000 pounds without crushing. The impact will not result in a uniform loading and there will be local spots that would see higher than the average pressure. However, the force required to stop the truck during the assumed impact is clearly much less than that required to cause significant damage to the concrete structure, thus preventing penetration to the IXCs.

The side of the vault that has the temporary storage cave is somewhat different in that the current outer wall is steel angle and lead blankets. If the interior space were to be filled with concrete and the curtains left to be the outer barrier, an impact from a vehicle would probably cut a portion of the blanket off and thus immediately reduce the radiation shielding from the internal IXCs. To mitigate this potential problem, it is proposed that the outside of the steel angle be sheathed with $1 / 2$ inch steel. The purpose of this plate is twofold, first, it would serve as the form to allow the interior space to be filled with the concrete, and second, it would serve as a front line barrier to an impact and distribute the load through the lead blankets and onto the concrete. The net result would be to provide the impact protection for this area. The determination of the thickness of the plate was made by weighing the required deflection of the steel under impact with the strength of the material. Carbon steel plate has a compression yield of $\sim 40,000 \mathrm{psi}$, and backed up by the concrete after a deflection due to the lead blanket would easily handle the load from the postulated impacting vehicle. The thinner the steel, the easier it is to deform it to the point of rupture, thus, it is our judgment that $1 / 2$ inch is reasonable for this application. The steel plate must be anchored to the existing concrete block either by using anchors into the existing 
block or by strapping it around the block. This will serve to prevent it from being sheared away from the structure in the case of an impact with a vehicle.

\subsubsection{Assessment of Monolith Resistance to Subsequent Fire}

The Society of Fire Protection Engineers (SFPE) develops methodologies and standards for the establishment of fire-resistance ratings for materials of constructions such as concrete and steel. The Fire Protection Engineering Handbook, published by SFPE, provides a graphical display (Figure 4-10.6) of the protection provided by various types of concrete for various concrete thicknesses (SFPE 1995). This graph is provided in Figure 5-2. As can be seen, the concrete thickness to provide a 2-hour fire endurance ranges between 3.6 inches for lightweight concrete and 5 inches for concrete containing siliceous aggregate. These same concrete thicknesses are also provided in Table 720.1(2) of the 2003 International Building Code for a fire resistance rating of 2 hours (ICC 2002). These concrete thicknesses are already provided for around the IXCs in the IXC Vault (see Section 2.2); however, it is unclear as to the location of the IXCs in the temporary storage cave. For this reason, it is recommended that the three IXCs in the cave be pushed back against the existing concrete vault wall and held there when the cave is filled with concrete. This will guarantee that a minimum of five inches of concrete is between the 0.5 -inch steel plate and each of the IXCs thus providing a 2-hour fire resistant wall in the unlikely event of a fire.

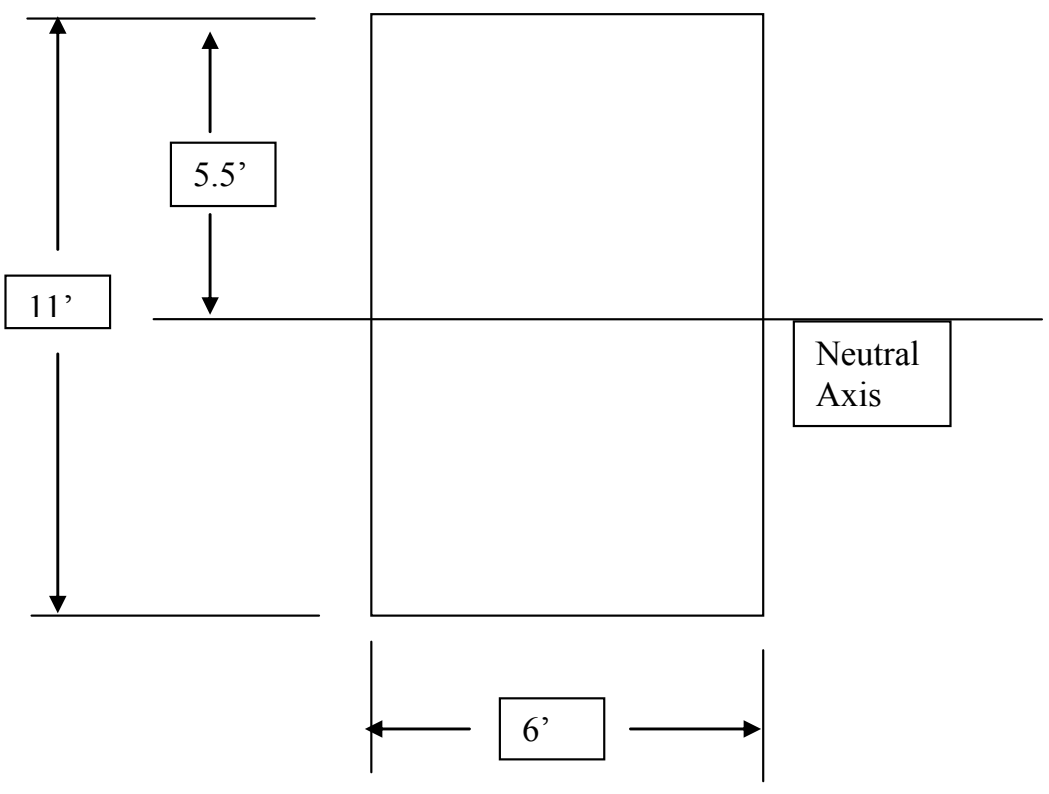

Figure 5-1. IXC Vault Neutral Axis 


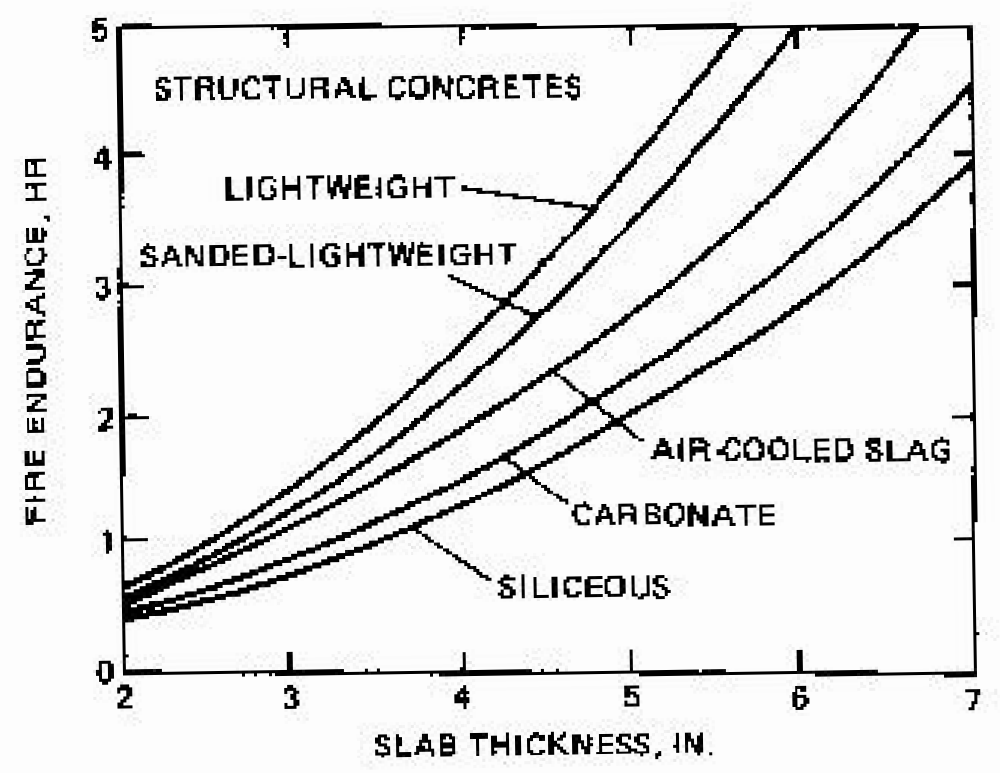

Figure 5-2. Fire Endurance of Concrete Slabs (SFPE 2002) 
This page intentionally left blank. 


\subsection{Conclusions and Recommendations}

The hazard analysis of the grouted IXC monolith postulated three potentially bounding accident conditions during D\&D of the basin that could result in a release of radioactive material from the IXCs. The hazard categorization analysis based on two of the accident conditions, a drop of the IXC monolith (MED-2-09) and a drop of a large/heavy object onto the monolith (MED-2-11), showed that the six grouted IXCs could be less that Hazard Category 3 using accident-specific ARFs and RFs to develop modified TQVs. However, the hazard categorization analysis for the third bounding accident condition, a large vehicle impact and subsequent diesel fuel or gasoline fire (MED-2-12), showed that this categorization was not possible if a release were to occur based on using accident-specific ARFs and RFs.

A subsequent structural assessment of the monolith, however, identified specific design features that, if incorporated during construction of the monolith, would protect the IXCs during each of the postulated accidents sufficiently to prevent a release of radioactive material from the IXCs; in other words, support use of a DR of 0 in the K East Basin hazard categorization analysis. Specific design requirements are as follows:

- Ensure a minimum of 5 inches of grout/concrete between the walls of the IXC and the outer walls of the monolith. This thickness of grout/concrete will provide sufficient fire resistance to protect the IXCs from a 2-hour fire. The IXC Vault, as currently configured, already meets this requirement. The IXCs in the IXC Cave would need to either be moved so as to abut up next to the IXC Vault wall and the cave filled with grout/concrete or additional concrete structure would need to be constructed around the outside of the cave sufficient to create the required 5-inch thickness.

- Incorporate a minimum 0.5 -inch thick steel plate surrounding all externally-exposed sides of the IXC Cave. This steel shield will distribute the force from the impact of a vehicle collision sufficiently to protect the IXCs in the IXC Cave from significant damage. Alternatively, a 1-foot thick reinforced concrete wall surrounding all externally exposed sides of the IXC would provide the same protection as the steel plate. In either case, the steel/reinforced concrete must be anchored to the existing concrete vault structure. The existing slightly reinforced concrete IXC Vault is judged to be adequate to protect the IXCs in this vault from significant damage from a vehicle collision.

- Incorporate a minimum 0.5 -inch thick steel plate covering the entire top of the concrete monolith. This steel shield will distribute the force from the impact of the postulated falling/dropped objects sufficiently to protect the IXCs from significant damage. This steel plate must be anchored to the concrete monolith.

- Ensure that the NUCFIL Filter is not plugged by any aggregate that may be included in the grout/concrete. The analysis in this report showed that over-pressurization of the IXCs from gas generation due to radiolysis is not an issue as long as the NUCFIL Filter is not plugged by aggregate (plugging by grout/concrete is not an issue). This recommendation can be achieved by either not including aggregate in the grout/concrete used to fill the void spaces between the IXCs and the vault/cave interior walls or by 
removing the NUCFIL Filter and leaving the 3-inch IXC inlet opening exposed to the grout/concrete fill.

These conclusions and recommendations are supported as long as the accident conditions assumed in the structural assessment, which are believed to be conservative, are not exceeded. 


\subsection{References}

Coles, G., S. Ross, J. Young, and J Williams. April 2005. Hazard Categorization Assessment for the K East Basin During Deactivation and Decommissioning Activities, SNF-22494, Rev. 0, Fluor Hanford, Inc., Richland, Washington.

DOE. 1997. Hazard Categorization and Accident Analysis Techniques for Compliance with DOE Order 5480.23 Nuclear Safety Analysis Reports, DOE-STD-1027-92, Change Notice No. 1, Department of Energy, Washington, D.C.

DOE. 2002. Methodology for Final Hazard Categorization for Nuclear Facilities from Category 3 to Radiological, Nuclear Safety Technical Position NSTP 2002-2, Department of Energy, Washington, D.C.

FH. 2003. K Basins Hazard Analysis, HNF-3960, Rev. 6, Fluor Hanford, Inc., Richland Washington.

Green, M.A. June 28, 2005. email message to Steven M. Short and Jeffrey L. Westcott having subject line IXC CALCS, Fluor Hanford, Inc., Richland, Washington.

ICC. 2002. 2003 International Building Code, International Code Council, Inc., Country Club Hills, Illinois.

SFPE. 1995. Handbook of Fire Protection Engineering, $2^{\text {nd }}$ Ed., Society of Fire Protection Engineers, Bethesda, Maryland.

WHC. November 1994. Hydrogen Production in the K Basin Ion Exchange Columns, Modules, and Cartridge Filters, WHC-SD-SNF-SARR-003, Rev. 0, Westinghouse Hanford Company, Richland, Washington. 
This page intentionally left blank. 
Appendix A

Preliminary Hazard Analysis Session Participants 
This page intentionally left blank. 


\section{Appendix A}

\section{Preliminary Hazard Analysis Session Participants}

The following attendees were present during the hazard analysis sessions:

Friday, June 10, 2004

Facilitator: Garill Coles

Scribe: Steve Short

Attendees:

\begin{tabular}{|l|l|}
\hline Paul Woods & Nuclear Safety \\
\hline Luis Valle & Structural Engineering \\
\hline Tom Orgill & D\&D Project Management \\
\hline Mary Ann Green & D\&D Project Engineering \\
\hline Jim Criddle & D\&D Project Engineering \\
\hline Jim Mathews & Operations \\
\hline Bill Clarkson & Fire Protection \\
\hline
\end{tabular}

A-1 
This page intentionally left blank.

A-2 
Appendix B

Process Description

B-i 
This page intentionally left blank. 


\section{Appendix B Process Description}

The activity assessed consists of grouting the IXCs, storing the grouted block and removing the grouted IXCs as a monolith. The IXCs will be grouted in place without being handled or moved. Form walls will constructed about a foot or two away from the concrete walls of the IXM walls and IXC lead curtains. The grout will be poured into the "formed up" area until all void spaces are filled. The top of the IXCs and IXMs will have one to two of grout covering them.

The grouted IXCs will remain in the basin as they are until they are cut out of the basin facility as a monolithic block and placed on a monolith transport carrier. Cutting the IXC/IXM grout block away from the basin structure will not involve cutting into the monolith. It was assumed that mobile cranes as large as 160 ton could be used during this placement activity.

Table B-1 show the sequence of tasks assumed in the original hazard categorization document (SNF-2294, Rev 0). The only difference that the proposed grouting of the IXCs does to this sequence is shown in the third row of the "Material and equipment disposition" activity.

Table B-1. Deactivation and Decommissioning Activity Definition Summary.

\begin{tabular}{|c|c|c|c|}
\hline D\&D Activities & Task Activities & $\begin{array}{c}\text { MAR Potentially } \\
\text { Impacted }\end{array}$ & Uncertainties with Tasks \\
\hline $\begin{array}{l}\text { Utility isolation } \\
\text { and services }\end{array}$ & $\begin{array}{l}\text { Isolation of sewage, electrical } \\
(480 \mathrm{~V}), \text { portable area monitors, } \\
\text { potable water, emergency and } \\
\text { normal makeup water, fire } \\
\text { suppression }\end{array}$ & All & -- \\
\hline \multirow{4}{*}{$\begin{array}{l}\text { Material and } \\
\text { equipment } \\
\text { disposition }\end{array}$} & $\begin{array}{l}\text { Removal of systems and } \\
\text { equipment }\end{array}$ & \multirow[t]{4}{*}{ All } & -- \\
\hline & Removal of sand filter & & $\begin{array}{l}\text { Removing inventory, quantity of sludge } \\
\text { Disposition options include transfer to } \\
\text { 105-KW Basin or directly to ERDF } \\
\end{array}$ \\
\hline & $\begin{array}{l}\text { Removal In-place grouting of } \\
\text { ion exchange columns and } \\
\text { modules }\end{array}$ & & $\begin{array}{l}\text { May be handled individually or as a group } \\
\text { Venting may or may not be required }\end{array}$ \\
\hline & $\begin{array}{l}\text { Removal of basin racks and } \\
\text { other debris }\end{array}$ & & $\begin{array}{l}\text { Disposition options include grouting in } \\
\text { place or transfer to ERDF }\end{array}$ \\
\hline \multirow[t]{2}{*}{$\begin{array}{l}\text { Cleaning of basin } \\
\text { surfaces }\end{array}$} & $\begin{array}{l}\text { Hydrolasing, high-pressure } \\
\text { washing }\end{array}$ & \multirow[t]{2}{*}{ All } & $\begin{array}{l}\text { Disposition options include (1) hydrolased } \\
\text { spoils placed in underwater containers and } \\
\text { grouted in place and (2) hydrolased spoils } \\
\text { placed in basin (uncontained) and grouted } \\
\text { in place }\end{array}$ \\
\hline & Disposition of hydrolased spoils & & -- \\
\hline $\begin{array}{l}\text { Basin grouting } \\
\text { and water } \\
\text { removal }\end{array}$ & $\begin{array}{l}\text { Grouting } \\
\text { Water removal }\end{array}$ & $\begin{array}{l}\text { All } \\
\text { Basin water, } \\
\text { water treatment }\end{array}$ & -- \\
\hline
\end{tabular}


Table B-1. Deactivation and Decommissioning Activity Definition Summary.

\begin{tabular}{|c|c|c|c|}
\hline D\&D Activities & Task Activities & $\begin{array}{c}\text { MAR Potentially } \\
\text { Impacted }\end{array}$ & Uncertainties with Tasks \\
\hline $\begin{array}{l}\text { Superstructure } \\
\text { demolition }\end{array}$ & Structure removal & $\begin{array}{l}\text { Grouted } \\
\text { contamination } \\
\text { and debris }\end{array}$ & -- \\
\hline $\begin{array}{l}\text { Reactor building } \\
\text { isolation }\end{array}$ & $\begin{array}{l}\text { Installation of closure } \\
\text { boundaries }\end{array}$ & Contamination & -- \\
\hline \multirow[t]{4}{*}{ Basin removal } & Excavation (horizontal boring) & \multirow{4}{*}{\begin{tabular}{|l|} 
Contamination \\
quantities \\
Leachate \\
collection system \\
Containerized \\
hydrolased \\
material \\
Contaminated soil
\end{tabular}} & $\begin{array}{l}\text { Handling cold joint separation issue } \\
\text { Process for limiting suspension of } \\
\text { material during lifting-drop, leachate } \\
\text { collection system disposition not defined }\end{array}$ \\
\hline & Cutting & & \multirow[t]{3}{*}{--} \\
\hline & Lifting & & \\
\hline & $\begin{array}{l}\text { Removal of leachate collection } \\
\text { system }\end{array}$ & & \\
\hline $\begin{array}{l}\mathrm{D \& D}= \\
\mathrm{ERDF}= \\
\mathrm{MAR}=\end{array}$ & $\begin{array}{l}\text { deactivation and decommissionin } \\
\text { Environmental Restoration Dispo } \\
\text { material at risk. }\end{array}$ & 1 Facility & \\
\hline
\end{tabular}


Appendix C

Hazard Identification Checklist

C-i 
This page intentionally left blank. 
Appendix C

\section{Hazard Identification Checklist}

Table C-1 presents a checklist that identifies hazards and energy sources associated with D\&D including grouting the IXCs and storing and removing the grouted IXC monolith. This identification was done using the hazard identification checklist from HNF-3960. All hazards in the current authorization basis were used as a starting point. New hazards were then identified for each D\&D activity and are shown in italics.

Table C-1. Hazard and Identification Checklist. (13 sheets)

\begin{tabular}{|c|c|c|c|}
\hline $\begin{array}{l}\text { Type of } \\
\text { Hazard }\end{array}$ & Form of Hazard & 105-K East Basin & $\begin{array}{l}\text { Other Supporting Structures, } \\
\text { Systems, and Components }\end{array}$ \\
\hline \multirow{9}{*}{$\begin{array}{l}\text { A. Electrical } \\
\text { Note: All } \\
\text { electrical hazards } \\
\text { are standard } \\
\text { industrial hazards } \\
\text { with the } \\
\text { exception of loss } \\
\text { of power, which } \\
\text { is covered by } \\
\text { external events } \\
\text { (see hazard P.4). }\end{array}$} & 1. Battery banks & NA & $\begin{array}{l}\text { Two battery banks in basement of } \\
165-K E \text { (used for switchgear, rectifiers, } \\
\text { and distribution panels - part of DC } \\
\text { system) }\end{array}$ \\
\hline & 2. Diesel units & $\begin{array}{l}\text { Diesel generators for temporary power } \\
\text { Temporary power units (outside the } \\
\text { basin) } \\
\text { Power for grout pumping (outside the } \\
\text { basin) }\end{array}$ & NA \\
\hline & 3. High voltage lines & NA & $230 \mathrm{kV}$ power poles \\
\hline & 4. Transformers & Power transformers & Power transformers \\
\hline & 5. Wiring & $\begin{array}{l}\text { AC-DC system } \\
\text { FTS STC transfer system } \\
\text { FTS annexes } \\
\text { SRS in NTB }\end{array}$ & AC-DC system \\
\hline & 6. Switchgear & $\begin{array}{l}480 \mathrm{~V} \text { switchgear at KE Basin } \\
\text { Temporary power from a } 480 \mathrm{~V} \\
\text { switchgear }\end{array}$ & $\begin{array}{l}230 \mathrm{kV} \text { switchgear at the } 151-\mathrm{K} \\
\text { substation } \\
13.8 \mathrm{kV} \text { switchgear in the } 165-\mathrm{K} \\
\text { Building } \\
480 \mathrm{~V} \text { switchgear } \\
\text { The system ends at the load side of the } \\
\text { motor control center or at the secondary } \\
\text { side of the transformers for voltages } \\
\text { below } 480 \mathrm{~V} \text {. }\end{array}$ \\
\hline & $\begin{array}{l}\text { 7. Underground } \\
\text { wiring }\end{array}$ & NA & Underground tunnel \\
\hline & 8. Cable runs & $\begin{array}{l}\text { Various cable raceways } \\
\text { Temporary cable raceways for temporary } \\
\text { power }\end{array}$ & Various cable raceways \\
\hline & $\begin{array}{l}\text { 9. Service outlets } \\
\text { and fittings }\end{array}$ & $\begin{array}{l}110 / 120 \mathrm{~V} \text { outlets are located throughout } \\
\text { the KE Basin } \\
\text { Temporary welding receptacles } \\
\text { GFIs are located throughout the basin }\end{array}$ & $\begin{array}{l}110 / 120 \mathrm{~V} \text { outlets } \\
\text { Temporary welding receptacle }\end{array}$ \\
\hline
\end{tabular}

\section{C-1}


Table C-1. Hazard and Identification Checklist. (13 sheets)

\begin{tabular}{|c|c|c|c|c|}
\hline & $\begin{array}{l}\text { Type of } \\
\text { Hazard }\end{array}$ & Form of Hazard & 105-K East Basin & $\begin{array}{l}\text { Other Supporting Structures, } \\
\text { Systems, and Components }\end{array}$ \\
\hline & $\begin{array}{l}\text { 10. Electric motor } \\
\text { driven pumps }\end{array}$ & $\begin{array}{l}\text { Recirculation pumps (3) } \\
\text { Skimmer pump } \\
\text { A-Sump pumps } \\
\text { B-Sump pumps } \\
\text { C-Sump pumps } \\
\text { D-Sump pumps } \\
\text { High-pressure pump for the PCM } \\
\text { Hydraulic pump for the manipulator } \\
\text { Pump for the chiller } \\
\text { Sludge pumping equipment (electrical } \\
\text { submersible pumps [Tri-Nuclear]) } \\
\text { Boiler circulation pumps } \\
\text { Air conditioning pumps } \\
\text { Air compressor } \\
\text { High-pressure pumps for debris cleaning } \\
\text { CTO lift platform hydraulic pump } \\
\text { SRS sludge transfer pumps } \\
\text { Sump pump for dewatering from reactor } \\
\text { side of discharge chute } \\
\text { Air movers } \\
\text { Sample pumps } \\
\text { Hydraulic power units }\end{array}$ & $\begin{array}{l}\text { River pumps, raw water pumps } \\
\text { (1,500-hp motor) } \\
\text { Potable water pumps (3) (300-hp motor) } \\
\text { Service water pumps (300-hp motor) } \\
\text { Backwash pumps (300-hp motor) } \\
\text { Water treatment facility pumps } \\
\text { Sample pumps } \\
\text { Outfall samplers } \\
\text { Outfall sample pumps, piping } \\
\text { Outfall temperature and flow monitoring } \\
\text { Low lift pumps } \\
\text { Septic system pumps } \\
\text { Air compressor } \\
\text { FTS lift platforms support structure } \\
\text { SRS sludge transfer pump support }\end{array}$ \\
\hline & & 11. Other motors & $\begin{array}{l}\text { Building exhaust fans } \\
\text { Air exhauster, sampler motors } \\
\text { Motor 3-way valves } \\
\text { Exhaust blowers (each basin has four, } \\
\text { roof mounted) } \\
\text { Each basin has two evaporative coolers } \\
\text { used for summer conditions } \\
\text { FTS straddle carrier motors } \\
\text { FTS STC lift platform motors } \\
\text { FTS work platform motor } \\
\text { FTS annexes rollup doors } \\
\text { CTO lift platform motor } \\
\text { SRS motor-operated valves }\end{array}$ & $\begin{array}{l}\text { Control-valve room (165-KE) contains } \\
\text { most motor- operated valves for raw and } \\
\text { service water systems } \\
\text { FTS STC lift platform support structure } \\
\text { SRS motor operated valve supports }\end{array}$ \\
\hline & & 12. Heaters & $\begin{array}{l}\text { Hot water boilers } \\
\text { Heat pumps } \\
\text { Portable heaters }\end{array}$ & $\begin{array}{l}\text { Unit heaters } \\
\text { Heat pumps } \\
\text { Water treatment structure unit heaters }\end{array}$ \\
\hline & & 13. Power tools & $\begin{array}{l}\text { Used during construction, maintenance, } \\
\text { and operations }\end{array}$ & $\begin{array}{l}\text { Used during construction, maintenance, } \\
\text { and operations }\end{array}$ \\
\hline
\end{tabular}

C-2 
Table C-1. Hazard and Identification Checklist. (13 sheets)

\begin{tabular}{|c|c|c|c|c|}
\hline & $\begin{array}{l}\text { Type of } \\
\text { Hazard }\end{array}$ & Form of Hazard & 105-K East Basin & $\begin{array}{l}\text { Other Supporting Structures, } \\
\text { Systems, and Components }\end{array}$ \\
\hline & \multirow[t]{2}{*}{$\begin{array}{l}\text { Electrical } \\
\text { (continued) }\end{array}$} & 14. Hoists & $\begin{array}{l}\text { Various electric hoists are mounted on } \\
\text { manually and motor-operated trolleys } \\
\text { rated up to } 32 \text { ton } \\
\text { Tractor motors for hoist and flexible } \\
\text { transfer crane } \\
\text { FTS annex crane main hoists } \\
\text { Annex crane auxiliary hoist } \\
\text { FTS STC lid hoist } \\
\text { Hoist for monorail to lift tremie pipe } \\
\text { Monorail hoist for waste loadout } \\
\text { Portable hoist and rigging equipment }\end{array}$ & $\begin{array}{l}\text { 15-ton bridge cranes } \\
\text { 25-ton bridge cranes } \\
\text { 20-ton annex bridge cranes } \\
\text { FTS STC lift platform support structure }\end{array}$ \\
\hline & & 16. Other & $\begin{array}{l}\text { Electrical roll-up doors } \\
\text { Instrumentation and cameras }\end{array}$ & $\begin{array}{l}\text { Traveling water intake screen } \\
\text { (motorized) } \\
\text { Raw water, bypass valve cross tie } \\
\text { (electric motorized) } \\
\text { Electrical roll-up doors }\end{array}$ \\
\hline & \multirow{9}{*}{$\begin{array}{l}\text { Nuclear } \\
\text { Criticality }\end{array}$} & 1. Vaults & NA & NA \\
\hline & & $\begin{array}{ll}2 . & \text { Temporary } \\
& \text { storage areas }\end{array}$ & $\begin{array}{l}\text { Accumulated sludge storage: } \\
\text { KE weasel pit } \\
\text { KE sand filter backwash pit (north } \\
\text { loadout pit) } \\
\text { KE floor sludge } \\
\text { Pit sludge containers: } \\
\text { KE technical view pit entrances } \\
\text { (north and south) } \\
\text { KE weasel pit proper } \\
\text { KE weasel pit entrance } \\
\text { Integrated Water Treatment System : } \\
\text { IXMs, sand filters } \\
\text { Sludge storage: } \\
\text { Main basins } \\
\text { SRS strainer basket } \\
\text { Sand filter media } \\
\text { Hydrolased spoils }\end{array}$ & NA \\
\hline & & 3. Receiving areas & NA & NA \\
\hline & & 4. Casks & $\begin{array}{l}\text { Chem-Nuclear cask, PAS-1 sampling } \\
\text { cask } \\
\text { STC } \\
\text { SRS LDC } \\
\text { SRS cask } \\
\end{array}$ & NA \\
\hline & & 5. Burial grounds & NA & NA \\
\hline & & 6. $\quad$ Storage tanks & NA & NA \\
\hline & & 7. Storage racks & NA & NA \\
\hline & & 8. Canals and basins & NA & NA \\
\hline & & 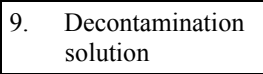 & NA & NA \\
\hline
\end{tabular}

C-3 
Table C-1. Hazard and Identification Checklist. (13 sheets)

\begin{tabular}{|c|c|c|c|c|}
\hline & $\begin{array}{l}\text { Type of } \\
\text { Hazard }\end{array}$ & Form of Hazard & 105-K East Basin & $\begin{array}{l}\text { Other Supporting Structures, } \\
\text { Systems, and Components }\end{array}$ \\
\hline \multirow[t]{6}{*}{ B. } & \multirow{6}{*}{$\begin{array}{l}\text { Nuclear } \\
\text { Criticality } \\
\text { (continued) }\end{array}$} & $\begin{array}{l}\text { 10. Trucks, forklifts, } \\
\text { dollies }\end{array}$ & IXM, IXC transport, cask transporters & IXM, IXC transport, cask transporters \\
\hline & & 11. Hand carry & NA & NA \\
\hline & & 12. Cranes and lifts & $\begin{array}{l}\text { Monorail and chain hoists; transfer bay } \\
\text { crane }\end{array}$ & NA \\
\hline & & $\begin{array}{l}\text { 13. Hot cells, } \\
\text { assembly }\end{array}$ & NA & NA \\
\hline & & 14. Inspection areas & NA & NA \\
\hline & & 15. Other & NA & NA \\
\hline \multirow[t]{8}{*}{ C. } & \multirow[t]{8}{*}{$\begin{array}{l}\text { Kinetic/ } \\
\text { Linear }\end{array}$} & 1. Cars, trucks, buses & $\begin{array}{l}\text { Trailer and truck } \\
\text { STS cask, LDC trailer and truck } \\
\text { Monolith transport carrier } \\
\text { Concrete trucks for grout delivery } \\
\text { Mobile crane }\end{array}$ & Trailer and truck \\
\hline & & $\begin{array}{l}\text { 2. Forklifts, dollies, } \\
\text { carts }\end{array}$ & $\begin{array}{l}\text { Forklift, dollies, carts, high lifters, man } \\
\text { lifts } \\
\text { Front end loader }\end{array}$ & $\begin{array}{l}\text { Forklift, dollies, carts used to move } \\
\text { storage containers in holding area } \\
\text { (low-level waste) }\end{array}$ \\
\hline & & 3. Railroad & Rail system deactivated & Rail system deactivated \\
\hline & & $\begin{array}{ll}\text { 4. } & \text { Obstructions } \\
\text { (collision with) }\end{array}$ & $\begin{array}{l}\text { Building structures, basin structures, and } \\
\text { process equipment }\end{array}$ & $\begin{array}{l}\text { Building structures and process } \\
\text { equipment }\end{array}$ \\
\hline & & $\begin{array}{l}\text { 5. Crane loads in } \\
\text { motion }\end{array}$ & $\begin{array}{l}\text { Canisters, IXMs, casks, debris, SRS PSP, } \\
\text { STS cask lid, spray shield } \\
\text { IXCs, sand filter, and basin monoliths } \\
\text { FTS annex cranes } \\
\text { Maintenance and construction loads }\end{array}$ & $\begin{array}{l}\text { Maintenance, construction and } \\
\text { warehousing loads; IXMs, IXCs } \\
\text { FTS annexes superstructure }\end{array}$ \\
\hline & & 6. PV blowdown & Compressed gas cylinders & Compressed gas cylinders \\
\hline & & 7. Other & $\begin{array}{l}\text { Moving STC straddle carrier } \\
\text { Moving FTS stiffback on monorail } \\
\text { extension } \\
\text { Demolition and excavator and shears }\end{array}$ & $\begin{array}{l}\text { STC lift platform structure and rail } \\
\text { system and annex rails } \\
\text { Basin monorails }\end{array}$ \\
\hline & & 8. Hoist & Hoists for grout piping & NA \\
\hline
\end{tabular}


Table C-1. Hazard and Identification Checklist. (13 sheets)

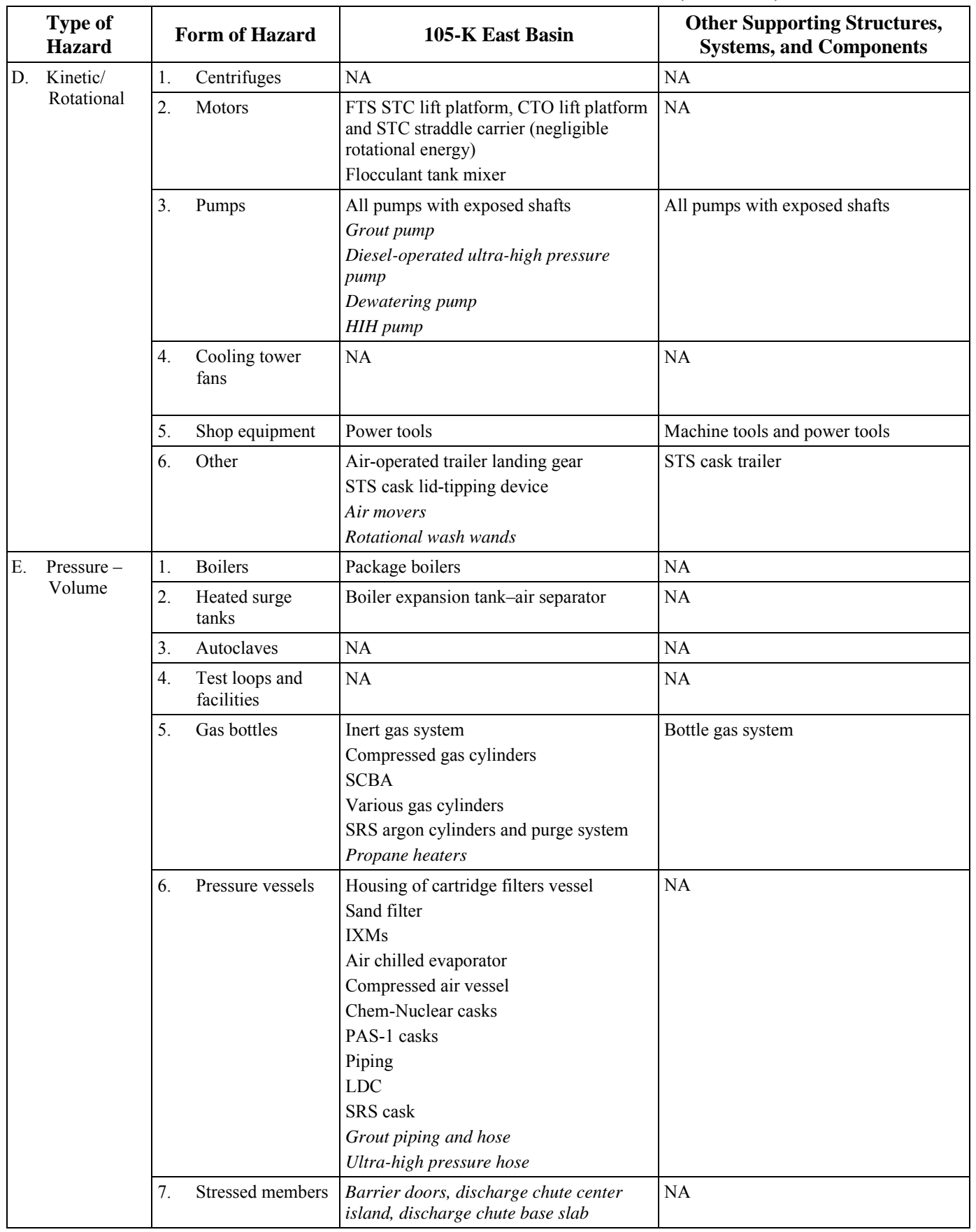


Table C-1. Hazard and Identification Checklist. (13 sheets)

\begin{tabular}{|c|c|c|c|c|}
\hline & $\begin{array}{l}\text { Type of } \\
\text { Hazard }\end{array}$ & Form of Hazard & 105-K East Basin & $\begin{array}{l}\text { Other Supporting Structures, } \\
\text { Systems, and Components }\end{array}$ \\
\hline \multirow[t]{3}{*}{ E. } & \multirow{3}{*}{$\begin{array}{l}\text { Pressure - } \\
\text { Volume } \\
\text { (continued) }\end{array}$} & 8. Gas receivers & Shop air receiver & Shop air receivers \\
\hline & & $\begin{array}{l}\text { 9. } \begin{array}{l}\text { Negative pressure } \\
\text { collapse }\end{array} \\
\end{array}$ & $\begin{array}{l}\text { NA } \\
\text { Hydrolased spoils collection system }\end{array}$ & NA \\
\hline & & 10. Other & $\begin{array}{l}\text { Pressurized water wands; } \\
\text { Trailer brakes } \\
\text { Compressed air for STC lift platform jack } \\
\text { screw brakes and for straddle carrier } \\
\text { locking pins (low pressure, small } \\
\text { volume) } \\
\text { Compressed air for STS LDC, cask } \\
\text { trailer suspension } \\
\text { SRS argon purge system } \\
\text { Hydrolasing system } \\
\text { Hydrolance (abrasive cutting equipment) }\end{array}$ & $\begin{array}{l}\text { STC lift platform } \\
\text { STC straddle carrier }\end{array}$ \\
\hline \multirow[t]{3}{*}{ F. } & \multirow[t]{3}{*}{$\begin{array}{l}\text { Mass, } \\
\text { Gravity, } \\
\text { Height }\end{array}$} & 1. Human effort & $\begin{array}{l}\text { Long-handled manual, automated tools } \\
\text { (with or without lifting assist devices): } \\
\text { Manual tongs, air-operated tong } \\
\text { Hand-operated trolley system } \\
\text { Moving carts } \\
\text { Maintenance, construction, and } \\
\text { operations } \\
\text { STC lid lock-unlock and manual } \\
\text { valve tool } \\
\text { STC lid hoist hook tool } \\
\text { SRS in-pool tools (suction wash, } \\
\text { strainer basket) } \\
\text { Other SRS tools (lid bolt, lid tilt, } \\
\text { LDC ports, drip cover, cask drain, } \\
\text { spray shield) } \\
\text { Shears, grippers } \\
\text { Direct piping method (grout lance) and } \\
\text { sweep }\end{array}$ & $\begin{array}{l}\text { Maintenance, construction, and } \\
\text { operations } \\
\text { Moving carts } \\
\text { Manual hoists }\end{array}$ \\
\hline & & 2. $\quad$ Stairs & $\begin{array}{l}\text { Various building stairs } \\
\text { Operations platform } \\
\text { Cask loadout trailer stairs }\end{array}$ & \begin{tabular}{|l} 
Various stairs \\
Water Treatment Facility
\end{tabular} \\
\hline & & 3. Lifts and cranes & $\begin{array}{l}\text { Canisters, } \\
\text { IXMs, casks } \\
\text { IXCs } \\
\text { Hydrolased spoils } \\
\text { Maintenance and construction loads } \\
\text { FTS STC lift platforms } \\
\text { FTS CTO lift platforms } \\
\text { FTS annex cranes } \\
\text { Bridge crane with cask lid, PSP, or spray } \\
\text { shield } \\
\text { Hoists for monorail } \\
\text { IXCs, sand filter, and basin monoliths }\end{array}$ & $\begin{array}{l}\text { Maintenance, construction, and } \\
\text { warehousing loads } \\
\text { IXMs, IXCs } \\
\text { Low-level waste containers } \\
\text { STC lift platform upper rail assembly } \\
\text { structures } \\
\text { FTS annex superstructures }\end{array}$ \\
\hline
\end{tabular}


Table C-1. Hazard and Identification Checklist. (13 sheets)

\begin{tabular}{|c|c|c|c|c|}
\hline & $\begin{array}{l}\text { Type of } \\
\text { Hazard }\end{array}$ & Form of Hazard & 105-K East Basin & $\begin{array}{l}\text { Other Supporting Structures, } \\
\text { Systems, and Components }\end{array}$ \\
\hline \multirow[t]{11}{*}{ F. } & \multirow{11}{*}{$\begin{array}{l}\text { Mass, } \\
\text { Gravity, } \\
\text { Height } \\
\text { (continued) }\end{array}$} & 4. Bucket and ladder & Maintenance activities & Maintenance activities \\
\hline & & 5. Trucks & $\begin{array}{l}\text { Truck deliveries in and out of the transfer } \\
\text { area } \\
\text { FTS cask transfer trailer } \\
\text { STS cask, LDC transport trailer } \\
\text { Grout truck }\end{array}$ & Truck deliveries in other areas \\
\hline & & 6. Slings & $\begin{array}{l}\text { Construction, maintenance, and } \\
\text { operations } \\
\text { CTO lifting fixtures } \\
\text { Rigging for grout piping }\end{array}$ & $\begin{array}{l}\text { Construction, maintenance, and } \\
\text { operations } \\
\text { FTS annex crane and hoist }\end{array}$ \\
\hline & & 7. Hoists & $\begin{array}{l}\text { Construction, maintenance, and } \\
\text { operations } \\
\text { FTS annex crane }\end{array}$ & $\begin{array}{l}\text { Construction, maintenance, and } \\
\text { operations } \\
\text { FTS annex }\end{array}$ \\
\hline & & 8. Elevators & NA & NA \\
\hline & & 9. Jacks & Truck jacks, pallet jacks & Truck jacks, pallet jacks \\
\hline & & $\begin{array}{ll}\text { 10. } & \begin{array}{l}\text { Scaffolds and } \\
\text { ladders }\end{array}\end{array}$ & $\begin{array}{l}\text { Construction, maintenance, and } \\
\text { operations } \\
\text { Ladders, slings }\end{array}$ & $\begin{array}{l}\text { Construction, maintenance, and } \\
\text { operations }\end{array}$ \\
\hline & & $\begin{array}{l}\text { 11. Pits and } \\
\text { excavations }\end{array}$ & $\begin{array}{l}\text { Basin and pits } \\
\text { Emptied basin }\end{array}$ & Construction activities \\
\hline & & 12. Elevated doors & FTS annex rollup doors & FTS annex superstructures \\
\hline & & 13. Vessels & $\begin{array}{l}\text { FTS, STC, and CTO } \\
\text { Sludge and Water System LDC and cask }\end{array}$ & NA \\
\hline & & 14. Other & $\begin{array}{l}\text { Building structure and grating } \\
\text { Roll-up door } \\
\text { Deteriorating roof } \\
\text { FTS-STC straddle carrier } \\
\text { FTS work platform } \\
\text { Monolith transport carrier }\end{array}$ & $\begin{array}{l}\text { Roll-up door } \\
\text { Deteriorating roof }\end{array}$ \\
\hline & \multirow[t]{6}{*}{$\begin{array}{l}\text { Flammable } \\
\text { Materials }\end{array}$} & 1. Packing materials & $\begin{array}{l}4 \times 4 \times 8 \text { shipping crates, pallets, plywood } \\
\text { waste boxes }\end{array}$ & $4 \times 4 \times 8$ shipping crates, pallets \\
\hline & & 2. Rags & Cleaning rags and anti-c & Cleaning rags \\
\hline & & 3. Gasoline & $\begin{array}{l}\text { Forklift, truck, and cranes } \\
\text { Fuel for grout pump } \\
\text { Gas or diesel for temporary power }\end{array}$ & $\begin{array}{l}\text { Gasoline fuel storage } \\
\text { Vehicles in parking lot }\end{array}$ \\
\hline & & 4. Oil & $\begin{array}{l}\text { Chiller, crane, hoist } \\
\text { Temporary power }\end{array}$ & $\begin{array}{l}\text { Motor oil } \\
\text { Bearing lubrication } \\
\text { Oil storage }\end{array}$ \\
\hline & & 5. Coolant oil & NA & NA \\
\hline & & 6. Paint solvent & Solvents and cleaners & Paints \\
\hline
\end{tabular}

C-7 
Table C-1. Hazard and Identification Checklist. (13 sheets)

\begin{tabular}{|c|c|c|c|c|}
\hline & $\begin{array}{l}\text { Type of } \\
\text { Hazard }\end{array}$ & Form of Hazard & 105-K East Basin & $\begin{array}{l}\text { Other Supporting Structures, } \\
\text { Systems, and Components }\end{array}$ \\
\hline \multirow[t]{10}{*}{ G. } & \multirow[t]{10}{*}{$\begin{array}{l}\text { Flammable } \\
\text { Materials } \\
\text { (continued) }\end{array}$} & 7. Diesel fuel & $\begin{array}{l}\text { Forklift used in waste accumulation area } \\
\text { - } 30 \text {-gal diesel fuel tank } \\
\text { Trucks in FTS annex portal (100 gal) } \\
\text { Mobile crane for construction purposes } \\
\text { Fuel for grout pump } \\
\text { Fuel for grout trucks } \\
\text { Fuel for mix station } \\
\text { Diesel fuel for temporary diesel power } \\
\text { (exterior) } \\
\text { Diesel fuel, pump external to the facility } \\
\text { for hydrolasing system. } \\
\text { Dewatering truck fuel } \\
\text { Refueling truck fuel } \\
\text { Excavator fuel }\end{array}$ & Truck, forklift, mobile cranes \\
\hline & & $\begin{array}{l}\text { 8. } \begin{array}{l}\text { Buildings and } \\
\text { contents }\end{array} \\
\text { t }\end{array}$ & $\begin{array}{l}\text { Building roofs, windbreak, electrical } \\
\text { installation material } \\
\text { Canister cleaning enclosure }\end{array}$ & $\begin{array}{l}\text { Building roofs, wood structures, } \\
\text { electrical installation material }\end{array}$ \\
\hline & & $\begin{array}{ll}\text { 9. } & \text { Trailers and } \\
\text { contents }\end{array}$ & $\begin{array}{l}\text { Personnel trailers (mobile offices), } \\
\text { vehicle tires }\end{array}$ & $\begin{array}{l}\text { Personnel trailers (mobile office), } \\
\text { vehicle tires }\end{array}$ \\
\hline & & 10. Grease & Small amount in bearings, gearboxes & Small amount in bearings, gearboxes \\
\hline & & $\begin{array}{l}\text { 11. Hydrogen } \\
\text { (including battery } \\
\text { banks) }\end{array}$ & $\begin{array}{l}\text { Canisters, basin sludge } \\
\text { IXMs, IXCs } \\
\text { FTS, STC, and CTO } \\
\text { STS, LDC, and cask } \\
\text { Hydrolased spoils hydrogen generation } \\
\end{array}$ & $\begin{array}{l}\text { IXCs, battery rooms each provided with } \\
\text { dedicated fans to ensure hydrogen gas is } \\
\text { released. }\end{array}$ \\
\hline & & 12. Nitric acid & NA & NA \\
\hline & & 13. Organics & $\begin{array}{l}\text { Decontamination solution } \\
\text { Flocculant }\end{array}$ & Decontamination solution \\
\hline & & 14. Gases - other & $\begin{array}{l}\text { Freon, chiller } \\
\text { Glycol, failure of basin heaters or piping } \\
\text { P-10 gas used for portal monitors } \\
\text { Oxygen, acetylene } \\
\text { Temporary propane heaters } \\
\text { Temporary kerosene heaters }\end{array}$ & Oxygen, acetylene \\
\hline & & 15. Spray paint & Maintenance use & Maintenance use and storage \\
\hline & & 16. Other & $\begin{array}{l}\text { Adjoining facility material storage } \\
\text { Visqueen } \\
\text { Plastic tarp (sleeving) } \\
\text { Fixative } \\
\text { Wood forming material and dunage }\end{array}$ & NA \\
\hline
\end{tabular}


Table C-1. Hazard and Identification Checklist. (13 sheets)

\begin{tabular}{|c|c|c|c|c|}
\hline & $\begin{array}{l}\text { Type of } \\
\text { Hazard }\end{array}$ & Form of Hazard & 105-K East Basin & $\begin{array}{l}\text { Other Supporting Structures, } \\
\text { Systems, and Components }\end{array}$ \\
\hline \multirow[t]{6}{*}{$\mathrm{H}$} & \multirow[t]{6}{*}{ Corrosives } & 1. Acids & Vehicle batteries & $\begin{array}{l}\text { Vehicle batteries } \\
\text { DC battery system }\end{array}$ \\
\hline & & 2. Caustics & Grout & Caustic cleaners \\
\hline & & $\begin{array}{l}\text { 3. "Natural" } \\
\text { chemicals (soil, } \\
\text { air, water) }\end{array}$ & NA & NA \\
\hline & & \begin{tabular}{|ll} 
4. & $\begin{array}{l}\text { Decontamination } \\
\text { solutions }\end{array}$ \\
\end{tabular} & $\begin{array}{l}\text { Maintenance use } \\
\text { Chem-search ifor decon }\end{array}$ & NA \\
\hline & & $\begin{array}{l}\text { 5. High temperature } \\
\text { waste }\end{array}$ & NA & NA \\
\hline & & 6. Other & $\begin{array}{l}\text { Nitric acid, sodium silicate } \\
\text { Chemical decontamination }\end{array}$ & NA \\
\hline \multirow[t]{5}{*}{$\mathrm{J}}$. & \multirow[t]{5}{*}{ Radiation } & 1. Canals & NA & NA \\
\hline & & 2. Plug storage & NA & NA \\
\hline & & 3. Storage areas & $\begin{array}{l}\text { Accumulated sludge storage: } \\
\text { KE weasel pit } \\
\text { KE sand filter backwash pit (north } \\
\text { loadout pit) } \\
\text { KE floor sludge } \\
\text { IXCs } \\
\text { Pit sludge containers: } \\
\text { KE technical view pit entrances } \\
\text { (north and south) } \\
\text { KE weasel pit proper } \\
\text { KE weasel pit entrance } \\
\text { Water treatment: } \\
\text { IXMs, sand filters, pumps and piping } \\
\text { Fuel storage: } \\
\text { Canisters } \\
\text { Sludge storage (temporary): } \\
\text { SRS strainer basket } \\
\text { SRS LDC (inside cask) } \\
\text { Basin wall surfaces } \\
\text { Discharge chute wall surfaces } \\
\text { Debris grouted in place } \\
\text { Sand filter media } \\
\text { Hydrolased spoils storage } \\
\text { Grouted hydrolased spoils }\end{array}$ & Storage pad (IXMs) \\
\hline & & 4. Storage buildings & NA & NA \\
\hline & & $\begin{array}{ll}\text { 5. } & \begin{array}{l}\text { Radioactive } \\
\text { sources }\end{array}\end{array}$ & Check sources & NA \\
\hline
\end{tabular}

C-9 
Table C-1. Hazard and Identification Checklist. (13 sheets)

\begin{tabular}{|c|c|c|c|c|}
\hline & $\begin{array}{l}\text { Type of } \\
\text { Hazard }\end{array}$ & Form of Hazard & 105-K East Basin & $\begin{array}{l}\text { Other Supporting Structures, } \\
\text { Systems, and Components }\end{array}$ \\
\hline \multirow[t]{13}{*}{$\mathrm{J}}$. & \multirow[t]{13}{*}{$\begin{array}{l}\text { Radiation } \\
\text { (continued) }\end{array}$} & 6. Waste and scrap & $\begin{array}{l}\text { Waste accumulation areas in transfer bay } \\
\text { of each basin } \\
\text { Tremie pipe } \\
\text { Thermally hot waste form }\end{array}$ & Waste pad shipping dock \\
\hline & & 7. Contamination & $\begin{array}{l}\text { Contaminated water and contaminated } \\
\text { areas } \\
\text { Discharge chute walls } \\
\text { Basin wall surfaces } \\
\text { Top of the finished grout } \\
\text { Grout pipe } \\
\text { Airborne radioactivity } \\
\text { Hydrolased spoils }\end{array}$ & NA \\
\hline & & $\begin{array}{ll}\text { 8. } & \text { Irradiated } \\
\text { experimental and } \\
\text { reactor equipment }\end{array}$ & NA & NA \\
\hline & & 9. Electric furnace & NA & NA \\
\hline & & $\begin{array}{ll}\text { 10. } & \text { Blacklight } \\
\text { (e.g., magniflux) }\end{array}$ & NA & NA \\
\hline & & 11. Laser & NA & NA \\
\hline & & 12. Medical x-ray & NA & NA \\
\hline & & $\begin{array}{l}\text { 13. } \begin{array}{l}\text { Radiography } \\
\text { equipment and } \\
\text { sources }\end{array} \\
\text { sour }\end{array}$ & Radiography for rebar scans & NA \\
\hline & & 14. Welding & $\begin{array}{l}\text { Construction and maintenance } \\
\text { Welding torch }\end{array}$ & Construction and maintenance \\
\hline & & $\begin{array}{l}\text { 15. Electric arc, other } \\
\text { (high-current } \\
\text { circuits) }\end{array}$ & Plasma torch & NA \\
\hline & & 16. Electron beam & NA & NA \\
\hline & & 17. Equipment noise & Pumps, motors, power tools, etc. & $\begin{array}{l}\text { Pumps, motors, power tools, etc. } \\
\text { Noise from venting of raw water pumps } \\
\text { (tunnel) }\end{array}$ \\
\hline & & $\begin{array}{l}\text { 18. Ultrasonic } \\
\text { cleaners }\end{array}$ & $\begin{array}{l}\text { NA } \\
\text { D\&D cleaning }\end{array}$ & NA \\
\hline
\end{tabular}


Table C-1. Hazard and Identification Checklist. (13 sheets)

\begin{tabular}{|c|c|c|c|c|}
\hline & $\begin{array}{l}\text { Type of } \\
\text { Hazard }\end{array}$ & Form of Hazard & 105-K East Basin & $\begin{array}{l}\text { Other Supporting Structures, } \\
\text { Systems, and Components }\end{array}$ \\
\hline \multirow[t]{13}{*}{ K. } & \multirow[t]{13}{*}{ Thermal } & $\begin{array}{l}\text { 1. Bunsen burner, } \\
\text { hot plates }\end{array}$ & NA & NA \\
\hline & & $\begin{array}{ll}\text { 2. } & \begin{array}{l}\text { Electrical } \\
\text { equipment }\end{array}\end{array}$ & $\begin{array}{l}\text { Unit heaters and space heaters } \\
\text { Electrical motors and pumps } \\
\text { Propane heaters }\end{array}$ & $\begin{array}{l}\text { Space heaters } \\
\text { Electrical furnaces heaters } \\
\text { Switchgear room } \\
\text { Electrical motors and pumps }\end{array}$ \\
\hline & & $\begin{array}{l}\text { 3. Furnaces, boilers, } \\
\text { heater }\end{array}$ & $\begin{array}{l}\text { NA } \\
\text { Propane heaters }\end{array}$ & Unit heaters \\
\hline & & 4. Steam lines & NA & NA \\
\hline & & 5. Welding torch, arc & $\begin{array}{l}\text { Construction and maintenance } \\
\text { Plasma, arc welding torch for } D \& D \\
\text { Cutting torch }\end{array}$ & Construction and maintenance \\
\hline & & $\begin{array}{l}\text { 6. Diesel units, fire } \\
\text { box, exhaust line }\end{array}$ & $\begin{array}{l}\text { Truck exhaust } \\
\text { Pump unit for grout } \\
\text { Grout trucks } \\
\text { Temporary power } \\
\text { External ultra-high pressure diesel water } \\
\text { pump }\end{array}$ & Truck exhaust \\
\hline & & $\begin{array}{l}\text { 7. Radioactive decay } \\
\text { heat }\end{array}$ & $\begin{array}{l}\text { Decay heat from sludge } \\
\text { FTS, STC } \\
\text { Packaged waste }\end{array}$ & NA \\
\hline & & \begin{tabular}{|ll} 
8. & $\begin{array}{l}\text { Exposed } \\
\text { components }\end{array}$ \\
\end{tabular} & NA & NA \\
\hline & & 9. $\quad$ Power tools & High-speed grinders & High-speed grinders \\
\hline & & 10. Convective & $\begin{array}{l}\text { Motors, lighting, instrumentation, control } \\
\text { panels }\end{array}$ & $\begin{array}{l}\text { Motors, lighting, instrumentation, } \\
\text { control panels }\end{array}$ \\
\hline & & 11. Solar & $\begin{array}{l}\text { FTS, STC, and CTO } \\
\text { Heat stress }\end{array}$ & NA \\
\hline & & 12. Cryogenic & NA & NA \\
\hline & & 13. Other & Heat of hydration from grout & NA \\
\hline & \multirow{6}{*}{$\begin{array}{l}\text { Explosive } \\
\text { Pyrophoric }\end{array}$} & 1. $\quad$ Caps & Demolition explosives & NA \\
\hline & & 2. $\quad$ Primer cord & Demolition explosives & NA \\
\hline & & 3. Dynamite & Demolition explosives & NA \\
\hline & & 4. Scrub chemicals & NA & NA \\
\hline & & 5. $\quad$ Dusts & NA & NA \\
\hline & & \begin{tabular}{|l} 
6. \\
Hydrogen \\
(including battery \\
banks and water \\
decomposition)
\end{tabular} & $\begin{array}{l}\text { Canisters } \\
\text { Basin sludge } \\
\text { FTS, STC, and CTO } \\
\text { SRS, LDC, and cask } \\
\text { IXCs, IXMs } \\
\text { Hydrolased spoils }\end{array}$ & $\begin{array}{l}\text { Battery rooms each provided with } \\
\text { dedicated fans to ensure hydrogen gas is } \\
\text { released. } \\
\text { IXCs }\end{array}$ \\
\hline
\end{tabular}


Table C-1. Hazard and Identification Checklist. (13 sheets)

\begin{tabular}{|c|c|c|c|c|}
\hline & $\begin{array}{l}\text { Type of } \\
\text { Hazard }\end{array}$ & Form of Hazard & 105-K East Basin & $\begin{array}{l}\text { Other Supporting Structures, } \\
\text { Systems, and Components }\end{array}$ \\
\hline \multirow[t]{6}{*}{ L. } & \multirow{6}{*}{$\begin{array}{l}\text { Explosive } \\
\text { Pyrophoric } \\
\text { (continued) }\end{array}$} & 7. Gases, other & $\begin{array}{l}\text { Hydrogen generation from aluminum } \\
\text { interaction with grout }\end{array}$ & NA \\
\hline & & 8. Nitrates & NA & NA \\
\hline & & 9. Peroxides & $\begin{array}{l}\text { Hydrogen peroxide used to control algae } \\
\text { in basins }\end{array}$ & NA \\
\hline & & $\begin{array}{l}\text { 10. Plutonium and } \\
\text { uranium metals }\end{array}$ & $\begin{array}{l}\text { Fuel assemblies, fuel scrap, uranium } \\
\text { hydrides } \\
\text { SRS strainer basket } \\
\text { STS, LDC } \\
\text { Basin sludge }\end{array}$ & NA \\
\hline & & 11. Sodium & NA & NA \\
\hline & & 12. Other & NA & $\begin{array}{l}\text { Plastic explosives for K-9 training aids; } \\
\text { bullets from patrol weapons }\end{array}$ \\
\hline & \multirow{12}{*}{$\begin{array}{l}\text { Hazardous } \\
\text { Material }\end{array}$} & 1. Alkali metals & NA & NA \\
\hline & & 2. Asphyxiants & $\begin{array}{l}\text { Basin water (drowning) } \\
\text { Vehicle exhaust } \\
\text { Inert gases for welding, maintenance, and } \\
\text { SRS }\end{array}$ & $\begin{array}{l}\text { Clearwells (underground water storage } \\
\text { reservoirs with depth } \sim 20 \mathrm{ft} \text { water) } \\
\text { (drowning) }\end{array}$ \\
\hline & & 3. Biologicals & Spiders, insects, snakes, mice & Spiders, insects, snakes, mice \\
\hline & & 4. Carcinogens & PCBs (in sludge) & $\begin{array}{l}\text { PCBs (possible residual from } \\
\text { transformers) }\end{array}$ \\
\hline & & 5. Corrosives & $\begin{array}{l}\text { Battery acid } \\
\text { Batteries as debris }\end{array}$ & $\begin{array}{l}\text { Vehicle battery acid } \\
\text { Battery room }\end{array}$ \\
\hline & & 6. Asbestos & Building, piping & Building, piping \\
\hline & & 7. Oxidizers & Decontamination agents & Decontamination agents \\
\hline & & $\begin{array}{l}\text { 8. Dusts and } \\
\text { particulates }\end{array}$ & $\begin{array}{l}\text { Sand and dust } \\
\text { Volcanic ash } \\
\text { Construction and demolition } \\
\text { Hydrolased particulate }\end{array}$ & $\begin{array}{l}\text { Sand and dust } \\
\text { Volcanic ash } \\
\text { Construction and demolition }\end{array}$ \\
\hline & & $\begin{array}{l}\text { 9. } \begin{array}{l}\text { Beryllium and } \\
\text { compounds }\end{array} \\
\end{array}$ & In-fuel braze rings (underwater) & Potentially $1706-\mathrm{KE}$ \\
\hline & & $\begin{array}{l}\text { 10. Chlorine and } \\
\text { compounds }\end{array}$ & NA & NA \\
\hline & & 11. Heavy metal & Plutonium., uranium, lead, lead paint & Lead, lead paint \\
\hline & & 12. Other & $\begin{array}{l}\text { Grout } \\
\text { Fixative - Fumes } \\
\text { Adequate ventilation from dusts, fumes, } \\
\text { gases, etc. (all activities) }\end{array}$ & $\begin{array}{l}\text { Sodium hydrochloride, aluminum } \\
\text { sulfate }\end{array}$ \\
\hline
\end{tabular}

\section{C-12}


Table C-1. Hazard and Identification Checklist. (13 sheets)

\begin{tabular}{|c|c|c|c|c|c|c|c|}
\hline \multicolumn{3}{|c|}{$\begin{array}{l}\text { Type of } \\
\text { Hazard }\end{array}$} & Form of Hazard & \multicolumn{2}{|l|}{ 105-K East Basin } & $\begin{array}{l}\text { Other Supporting Structures, } \\
\text { Systems, and Components }\end{array}$ & \\
\hline \multirow[t]{9}{*}{ N. } & \multicolumn{2}{|c|}{$\begin{array}{l}\text { Natural } \\
\text { Phenomena }\end{array}$} & 1. Earthquake & \multicolumn{2}{|c|}{$\begin{array}{l}\text { Design basis earthquake } \\
\text { Weakened structural strength of the basin } \\
\text { walls }\end{array}$} & Design basis earthquake & \\
\hline & & & 2. $\quad$ Flood & \multicolumn{2}{|l|}{$\overline{\mathrm{NA}}$} & Yes & \\
\hline & & & 3. $\quad$ Lightning & \multicolumn{2}{|l|}{ Yes } & Yes & \\
\hline & & & 4. $\quad$ Rain & \multicolumn{2}{|l|}{ Yes } & Yes & \\
\hline & & & \begin{tabular}{|ll}
5. & $\begin{array}{l}\text { Snow, freezing } \\
\text { weather }\end{array}$
\end{tabular} & \multicolumn{2}{|l|}{$\begin{array}{l}\text { Yes } \\
\text { Freeze protection for hydrolasing } \\
\text { activities }\end{array}$} & Yes & \\
\hline & & & 6. $\quad$ Straight wind & \multicolumn{2}{|l|}{$\begin{array}{l}\text { Yes } \\
\text { Open doors (door 158) }\end{array}$} & Yes & \\
\hline & & & \begin{tabular}{|ll} 
7. & Dust devil \\
\end{tabular} & \multicolumn{2}{|l|}{ (Covered by straight wind) } & (Covered by straight wind) & \\
\hline & & & 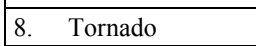 & \multicolumn{2}{|l|}{ (Covered by straight wind) } & (Covered by straight wind) & \\
\hline & & & 9. $\quad$ Ashfall & Yes & & NA & \\
\hline \multirow[t]{4}{*}{$\mathrm{P}$. } & \multirow{4}{*}{\multicolumn{2}{|c|}{$\begin{array}{l}\text { External } \\
\text { Events }\end{array}$}} & 1. $\quad$ Explosion & \multicolumn{2}{|l|}{$\begin{array}{l}\text { NA } \\
\text { Use of flammable gas for cutting }\end{array}$} & NA & \\
\hline & & & 2. $\quad$ Fire & \multicolumn{2}{|l|}{$\begin{array}{l}\text { Yes } \\
\text { Diesel truck to refill generator } \\
\text { Ultra-high pressure diesel water pump } \\
\end{array}$} & Yes & \\
\hline & & & $\begin{array}{ll}3 . & \begin{array}{l}\text { Events at other } \\
\text { sites }\end{array}\end{array}$ & \multicolumn{2}{|l|}{ Yes } & Yes & \\
\hline & & & \begin{tabular}{|l}
$4 . \quad$ Loss of power \\
\end{tabular} & \multicolumn{2}{|l|}{$\begin{array}{l}\text { Yes } \\
\text { Transition to temporary power(effects } \\
\text { and habitability) }\end{array}$} & Yes & \\
\hline \multirow[t]{5}{*}{ R. } & \multirow{5}{*}{\multicolumn{2}{|c|}{$\begin{array}{l}\text { Vehicles in } \\
\text { Motion } \\
\text { (external to } \\
\text { facility) }\end{array}$}} & 1. Airplane & \multicolumn{2}{|l|}{ Commercial, general, and military } & NA & \\
\hline & & & 2. $\quad$ Helicopter & \multicolumn{2}{|l|}{ Commercial, general, and military } & NA & \\
\hline & & & 3. $\quad$ Train & \multicolumn{2}{|l|}{ NA } & NA & \\
\hline & & & 4. $\quad$ Truck, bus, car & \multicolumn{2}{|c|}{$\begin{array}{l}\text { Only authorized vehicle travel permitted } \\
\text { within K Basin. Only two public roads } \\
\text { that cross the Hanford Site. Remaining } \\
\text { roads are restricted access roads. } \\
\text { Grout trucks } \\
\text { Service vehicles with flammable payloads } \\
\text { Increased vehicle traffic }\end{array}$} & NA & \\
\hline & & & 5. Other & River barge and boat traffic & & NA & \\
\hline & & $=$ & alternating current. & PCB & $=$ & polychlorinated biphenyl. & \\
\hline & СTO & $=$ & cask transfer overpack. & PCM & & Primary Clean Machine. & \\
\hline & & $=$ & deactivation and decom & missioning. & $=$ & primary sludge pump. & \\
\hline & & $=$ & direct current. & PV & $=$ & pressure vessel & Formatted: Tabs: $1.01 "$, Left + Not \\
\hline & FTS & $=$ & fuel transfer system. & NA & $=$ & not applicable. & at $0.43^{\prime \prime}$ \\
\hline & & $=$ & ground fault interrupter & SCBA & $=$ & self contained breathing apparatus. & \\
\hline & IXC & $=$ & ion-exchange column. & SRS & $=$ & Sludge Removal System. & \\
\hline & IXM & $=$ & ion-exchange module. & STC & $=$ & shielded transfer cask. & \\
\hline & $\mathrm{KE}$ & $=$ & K East. & STS & $=$ & Sludge Transportation System. & \\
\hline & KW & $=$ & K West. & TCA & $=$ & Transfer Cask Assembly & Formatted: Font: Bold \\
\hline & LDC & $=$ & large-diameter cask. & & & & \\
\hline
\end{tabular}


This page intentionally left blank.

C-14 


\section{Appendix D}

Preliminary Hazards Assessment Worksheets 
This page intentionally left blank.

D-ii 


\section{Appendix D}

\section{Preliminary Hazards Assessment Worksheets}

Table D-1 provides the information resulting from the Preliminary Hazard Analysis (PHA) sessions. Each row provides various attributes of a hazardous condition.

- Column 1 - Unique identifier for the hazardous condition

- Column 2 - Activity during which the postulated hazardous conditions could occur based on activities 1 through 7, as defined in the original hazard categorization assessment (SNF-22494)

- Column 3 - The material at risk

- Column 4 - The postulated hazardous condition, which is always defined as an uncontrolled release of material from a controlled location to an unwanted location

- Column 5-A brief description of the initiating cause of the uncontrolled release

- Column 6-A brief description of the physical consequences of the hazardous condition and an indication of how personnel are affected

- Column 7 - The frequency category for each hazardous condition.

- Column 8 - The consequence categories for effect on the public (maximally exposed offsite individual)

- Column 9 - The consequence categories for the effect on the onsite worker at $100 \mathrm{~m}$

- Column 10 - The consequence categories for the effect on the facility worker. 
Table D-1. Hazard Analysis Worksheet

\begin{tabular}{|c|c|c|c|c|c|c|c|c|c|c|c|}
\hline ID & Activity & $\begin{array}{c}\text { Material } \\
\text { At Risk }\end{array}$ & \multicolumn{1}{|c|}{$\begin{array}{c}\text { Hazardous } \\
\text { Condition }\end{array}$} & Candidate Causes & Consequences & $\begin{array}{c}\text { Freq } \\
\text { Cat }\end{array}$ & $\begin{array}{c}\text { Cons } \\
\text { Public }\end{array}$ & $\begin{array}{c}\text { Cons } \\
\text { Onsite }\end{array}$ & $\begin{array}{c}\text { Cons } \\
\text { FW }\end{array}$ & Env & Remarks \\
\hline $\begin{array}{l}\text { Activity 2: Material and Equipment Disposition } \\
\text { *New sub-activities - Grouting IXCs \& Storage and Loading Grouted IXCs for Removal }\end{array}$ & $\begin{array}{l}\text { Release of radioactive } \\
\text { and hazardous } \\
\text { material to facility } \\
\text { environment from } 6 \\
\text { IXCs due to breaching } \\
\text { caused by dropping } \\
\text { the grouted IXC } \\
\text { monolith. }\end{array}$ & $\begin{array}{l}\text { Human error or } \\
\text { failure of mobile } \\
\text { crane that results in } \\
\text { drop of grouted IXC } \\
\text { monolith. }\end{array}$ & $\begin{array}{l}\text { Airborne } \\
\text { particulates } \\
\text { into } \\
\text { environment. }\end{array}$ & A & L & L & N & E3 & $\begin{array}{l}\text { The grouted IXC monolith } \\
\text { is anticipated to be } \\
\text { lowered in-place onto the } \\
\text { transport trailer and not } \\
\text { lifted. }\end{array}$ \\
\hline MED-2-10 & 2 & 6 IXCs & & A & L & N & E2 & $\begin{array}{l}\text { Consequences same as } \\
\text { MED-2-12. Concrete } \\
\text { aalled buildings have an } \\
\text { inherent fire resistant } \\
\text { character depending on the } \\
\text { wall thickness. }\end{array}$ \\
\hline
\end{tabular}


Table D-1. Hazard Analysis Worksheet

\begin{tabular}{|c|c|c|c|c|c|c|c|c|c|c|c|}
\hline ID & Activity & $\begin{array}{l}\text { Material } \\
\text { At Risk }\end{array}$ & $\begin{array}{l}\text { Hazardous } \\
\text { Condition }\end{array}$ & Candidate Causes & Consequences & $\begin{array}{c}\text { Freq } \\
\text { Cat }\end{array}$ & $\begin{array}{l}\text { Cons } \\
\text { Public }\end{array}$ & $\begin{array}{l}\text { Cons } \\
\text { Onsite }\end{array}$ & $\begin{array}{c}\text { Cons } \\
\text { FW }\end{array}$ & Env & Remarks \\
\hline \multicolumn{12}{|c|}{ Activity 2: Material and Equipment Disposition } \\
\hline \multicolumn{12}{|c|}{ *New sub-activities - Grouting IXCs \& Storage and Loading Grouted IXCs for Removal } \\
\hline MED-2-11 & 2 & $6 \mathrm{IXCs}$ & $\begin{array}{l}\text { Release of radioactive } \\
\text { and hazardous } \\
\text { material to facility } \\
\text { environment from } 6 \\
\text { IXCs due to breaching } \\
\text { caused by the boom of } \\
\text { a large mobile crane } \\
\text { falling on or a basin I- } \\
\text { beam being dropped } \\
\text { on the grouted IXC } \\
\text { monolith. }\end{array}$ & $\begin{array}{l}\text { Human error or } \\
\text { mechanical failure } \\
\text { that results in drop of } \\
\text { large mobile crane } \\
\text { boom or I-beam onto } \\
\text { IXC monolith. } \\
\end{array}$ & $\begin{array}{l}\text { Airborne } \\
\text { particulates } \\
\text { into } \\
\text { environment. }\end{array}$ & A & $\mathrm{L}$ & $\mathrm{L}$ & $\mathrm{N}$ & E3 & $\begin{array}{l}\text { Mobile crane could be } \\
\text { capable of up to } 160 \text { ton } \\
\text { lift. }\end{array}$ \\
\hline MED-2-12 & 2 & $6 \mathrm{IXCs}$ & $\begin{array}{l}\text { Release of radioactive } \\
\text { and hazardous } \\
\text { material to facility } \\
\text { environment from } 6 \\
\text { IXCs due to breaching } \\
\text { caused vehicle impact } \\
\text { and subsequent fire. }\end{array}$ & $\begin{array}{l}\text { Human error or } \\
\text { mechanical failure } \\
\text { results in vehicle } \\
\text { impact (e.g. IXC } \\
\text { transport tractor) into } \\
\text { IXC monolith and } \\
\text { coincident breaching } \\
\text { of the fuel tank. }\end{array}$ & $\begin{array}{l}\text { Airborne } \\
\text { particulates } \\
\text { into } \\
\text { environment. } \\
\end{array}$ & A & $\mathrm{L}$ & L & $\mathrm{N}$ & E2 & $\begin{array}{l}\text { For vehicle traveling } \\
\text { within the } 20 \mathrm{mph} \text { speed } \\
\text { limit. }\end{array}$ \\
\hline MED-2-13 & 2 & $6 \mathrm{IXCs}$ & No release & $\begin{array}{l}\text { Hydrogen generation } \\
\text { in the IXC monolith } \\
\text { causes over- } \\
\text { pressurization or } \\
\text { deflagration. }\end{array}$ & No release & - & - & - & - & - & See Appendix E. \\
\hline
\end{tabular}


Table D-1. Hazard Analysis Worksheet

\begin{tabular}{|c|c|c|c|c|c|c|c|c|c|c|c|}
\hline ID & Activity & $\begin{array}{l}\text { Material } \\
\text { At Risk }\end{array}$ & $\begin{array}{l}\text { Hazardous } \\
\text { Condition }\end{array}$ & Candidate Causes & Consequences & $\begin{array}{c}\text { Freq } \\
\text { Cat }\end{array}$ & $\begin{array}{c}\text { Cons } \\
\text { Public }\end{array}$ & $\begin{array}{l}\text { Cons } \\
\text { Onsite }\end{array}$ & $\begin{array}{l}\text { Cons } \\
\text { FW }\end{array}$ & Env & Remarks \\
\hline \multicolumn{12}{|c|}{$\begin{array}{l}\text { Activity 2: Material and Equipment Disposition } \\
\text { *New sub-activities - Grouting IXCs \& Storage a }\end{array}$} \\
\hline MED-2-14 & 2 & 6 IXCs & No release & \begin{tabular}{|l|} 
Temperatures \\
reached from heat of \\
hydration expands \\
IXC vessel.
\end{tabular} & No release & - & - & - & - & - & $\begin{array}{l}\text { The amount of } \\
\text { grout/concrete fill used to } \\
\text { stabilize the IXCs will be } \\
\text { relatively small and is } \\
\text { deemed to be insufficient } \\
\text { to generate the amount of } \\
\text { heat that would be required } \\
\text { to deform the IXCs. }\end{array}$ \\
\hline MED-2-15 & 2 & $6 \mathrm{IXCs}$ & No release & $\begin{array}{l}\text { Cutting out the } \\
\text { monolith at the time } \\
\text { of removal from KE } \\
\text { Basin. }\end{array}$ & No release & - & - & - & - & - & $\begin{array}{l}\text { Because the IXCs will be } \\
\text { grouted by "forming-up" } \\
\text { around them, cutting will } \\
\text { not involve cutting thru the } \\
\text { grouted block. }\end{array}$ \\
\hline
\end{tabular}


Appendix E

Analysis of the Potential for Pressurization of an Ion Exchange Column Immobilized in Concrete 
This page intentionally left blank. 


\section{Appendix E \\ Analysis of the Potential for Pressurization of an Ion Exchange Column Immobilized in Concrete}

\section{E.1 Objective}

The objective of this analysis is to estimate the magnitude of pressure build-up within an IXC due to generated gases after it has been entombed in concrete for the purpose of determining whether IXC shell design is sufficient to prevent over-pressurization and rupture of the IXC.

\section{E.2 Analysis Approach}

Figure E-1 shows the model geometry for the analysis. An IXC of arbitrary volume generates hydrogen and oxygen at a known (bounding) rate. The IXC is vented prior to entombment. After entombment, concrete surrounds the IXC, and the vent is no longer exposed to the atmosphere. Concrete, however, is a porous medium and generated gases can both diffuse and flow through it. The path by which mass transfer occurs will be complex, due to the complex geometry involved. However, since the vent is small (both compared with the IXC diameter and the thickness of the concrete) an excellent approximation of the mass transfer can be achieved by assuming hemi-spherical conditions. Hence the idealized model to analyze is a source of gas introduced at the generation rate at the inner boundary of a hemi-spherical shell with radius $r_{1}$. The outer boundary of the shell is exposed to ambient conditions at radius $r_{2}$.

With the hemi-spherical model, the cross-sectional area of the inner boundary must be the same as the actual IXC circular vent. Hence, if $r_{v}$ is the vent radius, the equivalent radius of a hemi-sphere is given by

$$
r_{1}=r_{v} / \sqrt{2}
$$

The outer radius, $\mathrm{r}_{2}$, of the concrete shell is left arbitrary, and will be shown to be unimportant so long as it is large compared with the vent radius.

The approach used considers mass diffusion and porous flow separately. The actual mass transfer process will be a combination of both. The actual pressure in the IXC will be less than that predicted by considering the individual mechanisms. Therefore, the approach will provide a bounding result. 


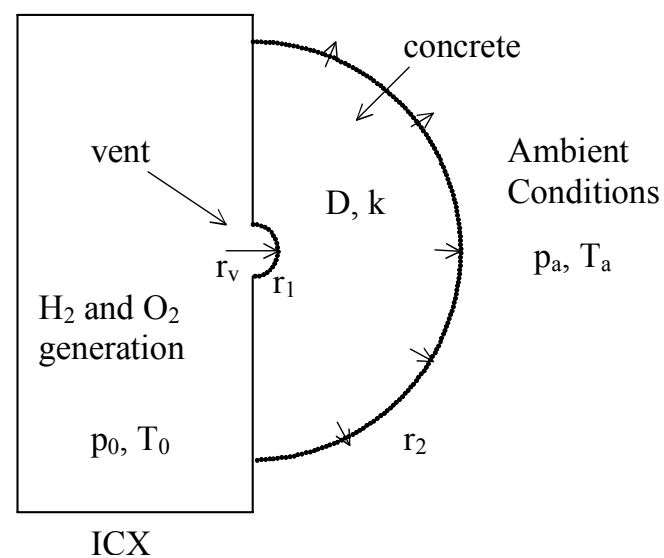

Figure E-1. Model geometry for mass transfer from an IXC vent through a hemi-spherical concrete region.

\section{E.3 Gas Generation Rate}

Flammable and non-flammable gases are continuously being generated in the IXCs due to radiolysis of residual water and resin. However, per SNF-11393, the gas production rate from radiolysis of water is much higher than that of resin and so this analysis only considers radiolysis of water. Furthermore, this analysis utilizes the same methodology in SNF-11393 to estimate the gas $\left(\mathrm{H}_{2}\right)$ generation rate, namely the use of the software program Radcalc Version $4.0^{\mathrm{b}}$. The Radcalc 4.0 software has been fully verified and validated in accordance with the software developer's DOE-approved Quality Assurance (QA) program ${ }^{\mathrm{c}}$.

IXCs 230 and 232, per Section 4.1 of this report, have the largest source terms and will therefore have the largest $\mathrm{H}_{2}$ generation rates of the six IXCs. These two IXCs were modeled with Radcalc 4.0 using the radionuclide source terms estimated in Section 4.1 of this report. Other key modeling assumptions, principally residual water content in the IXCs, volume and density of the resin material, and G-values for radioloysis of water, were assumed to be the same as assumed in SNF-11393, and which are considered reasonable and conservative assumptions for this analysis. Furthermore, this analysis conservatively assumed that all of the energy in emitted radiation from the decay of the source term is absorbed in the residual water thereby resulting in the generation of $\mathrm{H}_{2}$. In reality, some portion of the gamma radiation energy will be deposited in the IXC tank, IXC resin, other IXC internals, and concrete vault. This conservatism is estimated to be at least $10 \%$.

\footnotetext{
${ }^{a}$ P.G. Johnson. October 2002. Safety Basis for One-Time Transport of Two Concrete Boxes Containing Ion Exchange Columns, SNF-11393, Rev. 0, Fluor Hanford, Inc., Richland, Washington.

${ }^{\mathrm{b}}$ DOE. September 2004. Radcalc 4.0 available for download at http://WWW. doe-radcalc. com developed by Duratek Technical Services for the U.S. Department of Energy, National Transportation Program.

c DTS. April 2005. Radcalc Volume I: User's Manual, DTS-SQA-009.1, Rev. 0, Durtek Technical Services, Richland, Washington.
} 
The Radcalc 4.0 input data and calculation results are presented in Exhibit E-1 for IXC 230 and in Exhibit E-2 for IXC 232. As shown, the peak $\mathrm{H}_{2}$ generation rate, which is just after the IXCs have been grouted in place, for IXC 230 is $0.5368 \mathrm{~cm}^{3} / \mathrm{hr}(5.368 \mathrm{E}-04 \mathrm{l} / \mathrm{hr})$ and for IXC 232 is $0.5872 \mathrm{~cm}^{3} / \mathrm{hr}(5.872 \mathrm{E}-04 \mathrm{l} / \mathrm{hr})$. Since IXC 232 has the largest $\mathrm{H}_{2}$ gas generation rate of any of the six IXCs, $5.872 \mathrm{E}-04 \mathrm{l} / \mathrm{hr}$ is used in this analysis to determine the maximum pressure build-up in any of the IXCs.

\section{E.4 Binary Diffusion Through Concrete}

The steady state diffusion equation for a single gas species with molar concentration c $\left[\mathrm{moles} / \mathrm{m}^{3}\right]$ is given by

$$
\nabla^{2} \mathrm{c}=0
$$

For spherical coordinates, symmetric in radial spatial variable $r$, the diffusion equation is

$$
\frac{1}{\mathrm{r}} \frac{\partial}{\partial \mathrm{r}}\left(\mathrm{r}^{2} \frac{\partial \mathrm{c}}{\partial \mathrm{r}}\right)=0
$$

The general solution to Eq. (4.2) is given by

$$
\mathrm{c}(\mathrm{r})=\frac{\mathrm{a}}{\mathrm{r}}+\mathrm{b}
$$

Where $\mathrm{a}$ and $\mathrm{b}$ are constants to be determined from the boundary conditions.

The boundary condition at $r=r_{2}$ is $c\left(r_{2}\right)=c_{a}$ where $c_{a}$ is the concentration in ambient air of the diffusing species. Hence the constant $\mathrm{b}$ in $\mathrm{Eq}$ (4.3) is found to be

$$
\mathrm{b}=\mathrm{c}_{\mathrm{a}}-\mathrm{a} / \mathrm{r}_{2}
$$

and Eq. (4.3) can be written

$$
\mathrm{c}(\mathrm{r})=\mathrm{c}_{\mathrm{a}}+\mathrm{a}\left(\frac{1}{\mathrm{r}}-\frac{1}{\mathrm{r}_{2}}\right)
$$

The boundary condition at $r=r_{1}$ is that the molar generation rate of gas within the IXC is equal to the molar diffusion rate. 
Let $\mathrm{G}_{\mathrm{V}}\left[\mathrm{m}^{3} / \mathrm{s}\right]$ be the single-gas species volume generation rate at standard conditions. The ideal gas law is given by

$$
\mathrm{pV}=\mathrm{NRT}
$$

where $\mathrm{p}$ is the pressure $(\mathrm{Pa}), \mathrm{V}$ is the volume $\left(\mathrm{m}^{3}\right), \mathrm{N}$ is the number of moles, $\mathrm{R}$ is the universal gas constant $(\mathrm{kJ} / \mathrm{mole}-\mathrm{K})$, and $\mathrm{T}$ is the absolute temperature $(\mathrm{K})$.

Then the molar generation rate $\mathrm{G}_{\mathrm{N}}[\mathrm{moles} / \mathrm{s}]$ is given by

$$
\mathrm{G}_{\mathrm{N}}=\mathrm{G}_{\mathrm{v}} \frac{\mathrm{p}_{\mathrm{a}}}{\mathrm{RT}_{\mathrm{a}}}
$$

where it has been assumed that the difference between standard and ambient conditions (subscript a) is negligible.

If $D$ is the mass diffusion coefficient in concrete $\left[\mathrm{m}^{2} / \mathrm{s}\right]$, then the molar flux $\mathrm{j}\left[\mathrm{moles} / \mathrm{m}^{2}\right.$ s] is given by Fick's law

$$
\mathrm{j}=-\mathrm{D} \frac{\partial \mathrm{c}}{\partial \mathrm{r}}
$$

The molar diffusion rate in concrete is $2 \pi \mathrm{r}^{2} \times \mathrm{j}(\mathrm{moles} / \mathrm{s})$. Hence the molar diffusion rate is given by combining Eq. (4.8) and (4.5) as

$$
\text { molar diffusion rate }=2 \pi \mathrm{r}^{2}\left(-\mathrm{D} \frac{\partial \mathrm{c}}{\partial \mathrm{r}}\right)=2 \pi \mathrm{r}^{2}\left(\mathrm{a} / \mathrm{r}^{2}\right)=2 \pi \mathrm{aD}
$$

The boundary condition at $r=r_{1}$ is therefore

$$
\mathrm{G}_{\mathrm{N}}=2 \pi \mathrm{aD}
$$

or solving for the constant a

$$
\mathrm{a}=\frac{\mathrm{G}_{\mathrm{N}}}{2 \pi \mathrm{D}}
$$

Hence Eq. (4.5) becomes 


$$
\mathrm{c}(\mathrm{r})=\mathrm{c}_{\mathrm{a}}+\frac{\mathrm{G}_{\mathrm{v}} \mathrm{p}_{\mathrm{a}}}{2 \pi \mathrm{DRT}_{\mathrm{a}}}\left(\frac{1}{\mathrm{r}}-\frac{1}{\mathrm{r}_{2}}\right)
$$

The concentration can be written in terms of the partial pressure of the diffusing gas

$$
\mathrm{c}=\frac{\mathrm{N}}{\mathrm{V}}=\frac{\mathrm{p}}{\mathrm{RT}}
$$

For ambient conditions we can write

$$
\mathrm{c}_{\mathrm{a}}=\frac{\mathrm{N}}{\mathrm{V}_{\mathrm{a}}}=\frac{\phi \mathrm{p}_{\mathrm{a}}}{\mathrm{RT}_{\mathrm{a}}}
$$

where $\phi$ is the volume fraction of the diffused species in ambient air (i.e. $\phi=0$ for $\mathrm{H}_{2}$ and $\phi \cong 0.2$ for $\mathrm{O}_{2}$.)

Hence Eq. (4.12) can be written in terms of pressure

$$
\mathrm{p}(\mathrm{r})=\phi \mathrm{p}_{\mathrm{a}}+\frac{\mathrm{G}_{\mathrm{v}} \mathrm{p}_{\mathrm{a}}}{2 \pi \mathrm{D}} \frac{\mathrm{T}}{\mathrm{T}_{\mathrm{a}}}\left(\frac{1}{\mathrm{r}}-\frac{1}{\mathrm{r}_{2}}\right)
$$

To find the pressure in the IXC at steady state, Eq. (4.15) is evaluated at $r=r_{1}$

$$
\mathrm{p}_{0}=\phi \mathrm{p}_{\mathrm{a}}+\frac{\mathrm{G}_{\mathrm{v}} \mathrm{p}_{\mathrm{a}}}{2 \pi \mathrm{Dr}_{1}} \frac{\mathrm{T}_{0}}{\mathrm{~T}_{\mathrm{a}}}\left(1-\frac{\mathrm{r}_{1}}{\mathrm{r}_{2}}\right)
$$

If we assume that $T_{0} \approx T_{a}$ (i.e. the heat load in the IXC is small), and note also that $r_{1} / r_{2}$ is much smaller than 1, then Eq. (4.16) can be written

$$
\frac{\mathrm{p}_{0}}{\mathrm{p}_{\mathrm{a}}}=\phi+\frac{\mathrm{G}_{\mathrm{V}}}{2 \pi \mathrm{Dr}}
$$


Equation (4.17) gives the steady state partial pressure inside the IXC when a generated gas species diffuses through concrete. The equation can be applied independently for the primary generated species $\left(\mathrm{H}_{2} \& \mathrm{O}_{2}\right)$ as well as the primary non-diffusive species $\mathrm{N}_{2}$ (nondiffusing because it is not generated within the IXC and its concentration remains uniform). The net pressure within the IXC will be given by the sum of the partial pressures.

Hence for the gas mixture we can write

$$
\begin{aligned}
& \frac{\mathrm{p}_{\mathrm{k}}}{\mathrm{p}_{\mathrm{a}}}=\phi_{\mathrm{k}}+\frac{\mathrm{G}_{\mathrm{vk}}}{2 \pi \mathrm{D}_{\mathrm{k}} \mathrm{r}_{1}} \\
& \mathrm{p}_{0}=\sum \mathrm{p}_{\mathrm{k}}
\end{aligned}
$$

For hydrogen we have

$$
\begin{aligned}
& \mathrm{G}_{\mathrm{VH}_{2}} \text { given } \\
& \phi_{\mathrm{H}_{2}}=0 \\
& \mathrm{D}_{\mathrm{H}_{2}} \text { given }
\end{aligned}
$$

For oxygen we have

$$
\begin{gathered}
\mathrm{G}_{\mathrm{VO}_{2}}=\frac{1}{2} \mathrm{G}_{\mathrm{VH}_{2}}\left(2 \mathrm{H}_{2} \mathrm{O} \rightarrow 2 \mathrm{H}_{2}+\mathrm{O}_{2}\right) \\
\phi_{\mathrm{O}_{2}} \approx 0.2 \quad \text { (nominal concentration of oxygen in air) } \\
\mathrm{D}_{\mathrm{O}_{2}} \approx \sqrt{\frac{\mathrm{M}_{\mathrm{H}_{2}}}{\mathrm{M}_{\mathrm{O}_{2}}} \mathrm{D}_{\mathrm{H}_{2}}}=\frac{1}{4} \mathrm{D}_{\mathrm{H}_{2}}
\end{gathered}
$$

Equation (4.20) is based on the assumption, that if the diffusion rate for hydrogen is known, the diffusion rate of any other gas will be proportional to the square root of the molecular weights.

For nitrogen (plus the balance of non-diffusing gases) we have 


$$
\begin{aligned}
& \mathrm{G}_{\mathrm{VN}_{2}} \approx 0 \\
& \phi_{\mathrm{N}_{2}} \approx 0.8 \quad \text { (nominal concentration of nitrogen in air) }
\end{aligned}
$$

With these relations, Eq. (4.18) can be evaluated for each species to give

$$
\begin{aligned}
& \frac{\mathrm{p}_{0 \mathrm{H}_{2}}}{\mathrm{p}_{\mathrm{a}}}=\frac{\mathrm{G}_{\mathrm{VH}_{2}}}{2 \pi \mathrm{D}_{\mathrm{H}_{2}} \mathrm{r}_{1}} \\
& \frac{\mathrm{p}_{0 \mathrm{O}_{2}}}{\mathrm{p}_{\mathrm{a}}}=0.2+\frac{\mathrm{G}_{\mathrm{VH}_{2}}}{4 \pi \mathrm{D}_{\mathrm{H}_{2}} \mathrm{r}_{1}} \\
& \frac{\mathrm{p}_{0 \mathrm{~N}_{2}}}{\mathrm{p}_{\mathrm{a}}}=0.8
\end{aligned}
$$

By summing Eq. (4.21) - (4.23) we get the steady state pressure inside the IXC

$$
\frac{\mathrm{p}_{0}}{\mathrm{p}_{\mathrm{a}}}=1+\frac{3 \mathrm{G}_{\mathrm{VH}_{2}}}{2 \pi \mathrm{D}_{\mathrm{H}_{2}} \mathrm{r}_{1}}
$$

Evaluating Eq. (4.24) for the following conditions

$$
\begin{aligned}
& \mathrm{G}_{\mathrm{VH}_{2}}=5.87 \times 10^{-4} 1 / \mathrm{hr}=1.63 \times 10^{-10} \mathrm{~m}^{3} / \mathrm{s} \text { (from Section E.2) } \\
& \mathrm{D}_{\mathrm{H}_{2}}=3.3 \times 10^{-4} \mathrm{~cm}^{2} / \mathrm{s}=3.3 \times 10^{-8} \mathrm{~m}^{2} / \mathrm{s} \\
& \mathrm{d}_{\mathrm{v}}
\end{aligned}
$$

\footnotetext{
${ }^{\mathrm{d}}$ From J.E. Meacham. June 2003. Flammable Gas Diffusion from Waste Transfer Associated Structures, RPP12710, Rev. 1, CH2MHill Hanford Group, Richland, Washington. The value of $3.3 \times 10^{-4} \mathrm{~cm}^{2} / \mathrm{s}$ is conservative in that it is the lower limit for the diffusivity of $\mathrm{H}_{2}$ gas through dry concrete reported in this document. The range for $\mathrm{H}_{2}$ diffusivity in dry concrete extended up to a maximum reported value of $9.2 \times 10^{-3} \mathrm{~cm}^{2} / \mathrm{s}$.
} 


$$
\mathrm{r}_{1}=\mathrm{r}_{\mathrm{v}} / \sqrt{2}=1.12 \times 10^{-3} \mathrm{~m}
$$

For these values, Eq. (4.22) gives

$\underline{\mathrm{p}_{0}}=3.11$

$\mathrm{p}_{\mathrm{a}}$

With $\mathrm{p}_{\mathrm{a}}=14.7 \mathrm{psia}$, the steady state pressure inside the IXC is $\mathrm{p}_{0}=45.7 \mathrm{psia}=31.0 \mathrm{psig}$.

\section{E.5 Porous Flow Through Concrete}

Darcy's law for porous flow (neglecting gravity) is given by

$$
\mathrm{v}=-\frac{\mathrm{k}}{\mu} \nabla \mathrm{p}
$$

where $\mathrm{p}$ is the pressure $(\mathrm{Pa}), \mathrm{v}$ is the superficial velocity $(\mathrm{m} / \mathrm{s}), \mathrm{k}$ is the permeability $\left(\mathrm{m}^{2}\right)$ of concrete, and $\mu$ is the viscosity (Pa-s) of the ideal gas mixture.

The equation of mass continuity for steady flow is given by

$$
\nabla \bullet \rho \mathrm{v}=0
$$

where $\rho$ is the gas density $(\mathrm{kg} / \mathrm{m} 3)$.

The ideal gas law, written in terms of the density, is given by

$$
p=\rho R_{m} T
$$

where $R_{m}$ is the gas constant per unit mass $(\mathrm{kJ} / \mathrm{kg}-\mathrm{K})$.

Equations (5.1) - (5.3) govern the steady-state porous gas flow through the concrete. With the assumption of isothermal conditions, these equations can be combined to obtain

$$
\nabla^{2} \mathrm{p}^{2}=0
$$


For spherical coordinates, symmetric in radial spatial variable r, Eq. (5.4) is

$$
\frac{1}{\mathrm{r}} \frac{\partial}{\partial \mathrm{r}}\left(\mathrm{r}^{2} \frac{\partial \mathrm{p}^{2}}{\partial \mathrm{r}}\right)=0
$$

The general solution to Eq. (5.5) is given by

$$
\mathrm{p}(\mathrm{r})=\sqrt{\frac{\mathrm{a}}{\mathrm{r}}+\mathrm{b}}
$$

where $\mathrm{a}$ and $\mathrm{b}$ are constants to be determined from the boundary conditions.

The boundary condition at $r=r_{2}$ is $p\left(r_{2}\right)=p_{a}$ where $p_{a}$ is the ambient air pressure. Hence the constant $\mathrm{b}$ in $\mathrm{Eq}$ (5.6) is found to be

$$
\mathrm{b}=\mathrm{p}_{\mathrm{a}}^{2}-\mathrm{a} / \mathrm{r}_{2}
$$

and Eq. (5.6) can be written

$$
\mathrm{p}^{2}(\mathrm{r})=\mathrm{p}_{\mathrm{a}}^{2}+\mathrm{a}\left(\frac{1}{\mathrm{r}}-\frac{1}{\mathrm{r}_{2}}\right)
$$

The boundary condition at $r=r_{1}$ (and all $r$ ) is that the molar generation rate, $G_{N}$, of gas within the IXC is equal to the molar flow rate through the concrete. The molar flow rate is the molar flux $(\mathrm{N} / \mathrm{V}) \mathrm{v}$ multiplied by the cross-sectional area $2 \pi \mathrm{r}^{2}$. Hence the molar flow rate is given by

$$
\text { molar flow rate }=2 \pi r^{2} \frac{N}{V} v=-2 \pi r^{2} \frac{N}{V} \frac{k}{\mu} \nabla p=-2 \pi r^{2} \frac{p}{R_{m} T} \frac{k}{\mu} \nabla p
$$

Since $\nabla p^{2}=2 p \nabla p$, it follows from Eq. (5.8) that

$$
\nabla \mathrm{p}=\frac{\nabla \mathrm{p}^{2}}{2 \mathrm{p}}=\frac{1}{2 \mathrm{p}}\left(-\frac{\mathrm{a}}{\mathrm{r}^{2}}\right)=-\frac{\mathrm{a}}{2 \mathrm{pr}^{2}}
$$


Substituting Eq. (5.10) into Eq. (5.9) gives

$$
\text { molar flow rate }=\frac{k a \pi}{\mu R_{m} T_{a}}
$$

where again it has been assumed that the temperature is a constant equal to the ambient value.

The boundary condition therefore gives

$$
\mathrm{a}=\frac{\mu \mathrm{R}_{\mathrm{m}} \mathrm{T}_{\mathrm{a}} \mathrm{G}_{\mathrm{N}}}{\pi \mathrm{k}}
$$

Therefore Eq. (5.8) can becomes

$$
\mathrm{p}^{2}(\mathrm{r})=\mathrm{p}_{\mathrm{a}}^{2}+\frac{\mu \mathrm{R}_{\mathrm{m}} \mathrm{T}_{\mathrm{a}} \mathrm{G}_{\mathrm{N}}}{\pi \mathrm{k}}\left(\frac{1}{\mathrm{r}}-\frac{1}{\mathrm{r}_{2}}\right)
$$

In terms of the total gas volume generation rate, Eq. (4.13) is

$$
\mathrm{p}^{2}(\mathrm{r})=\mathrm{p}_{\mathrm{a}}^{2}+\frac{\mu \mathrm{p}_{\mathrm{a}} \mathrm{G}_{\mathrm{V}}}{\pi \mathrm{k}}\left(\frac{1}{\mathrm{r}}-\frac{1}{\mathrm{r}_{2}}\right)
$$

Evaluating Eq. (5.14) at $r=r_{1}$, and recognizing again that $r_{1} / r_{2}$ is much smaller than 1, then the expression for the pressure inside the IXC is

$$
\left(\frac{\mathrm{p}_{0}}{\mathrm{p}_{\mathrm{a}}}\right)^{2}=1+\frac{\mu \mathrm{G}_{\mathrm{v}}}{\pi \mathrm{kp}_{\mathrm{a}} \mathrm{r}_{1}}
$$

Equation (5.15) gives the steady state pressure inside the IXC when a generated gas species flows through the porous concrete. The equation governs the gas mixture $\left(\mathrm{H}_{2} \& \mathrm{O}_{2}\right)$

Evaluating Eq. (5.15) for the following conditions

$$
\begin{aligned}
& \mathrm{G}_{\mathrm{V}}=\mathrm{G}_{\mathrm{VH}_{2}}+\mathrm{G}_{\mathrm{VO}_{2}}=3 / 2 \mathrm{G}_{\mathrm{VH}_{2}} \\
& \mathrm{G}_{\mathrm{V}}=3 / 2\left(5.87 \times 10^{-4} \mathrm{l} / \mathrm{hr}\right)=2.44 \times 10^{-10} \mathrm{~m}^{3} / \mathrm{s}
\end{aligned}
$$

E-10 


$$
\begin{aligned}
& \mathrm{k}=1 \times 10^{-18.75 \pm 0.75} \mathrm{~m}^{2} \mathrm{e}^{-6} \mathrm{~Pa} \cdot \mathrm{s}^{\mathrm{f}} \\
& \mu_{\mathrm{H}_{2}}=8.96 \times 10^{-6} \\
& \mu_{\mathrm{O}_{2}}=2.06 \times 10^{-5} \mathrm{~Pa} \cdot \mathrm{s}
\end{aligned}
$$

Assume conservatively that $\mu=\mu_{\mathrm{O}_{2}}$

$$
\begin{aligned}
& r_{v}=1 / 16 \text { in }=1.59 \times 10^{-3} \mathrm{~m} \\
& r_{1}=r_{v} / \sqrt{2}=1.12 \times 10^{-3} \mathrm{~m} \\
& p_{a}=101325 \mathrm{~Pa}
\end{aligned}
$$

For these values, Eq. (5.15) gives

$$
\frac{\mathrm{p}_{0}}{\mathrm{p}_{\mathrm{a}}}=3.89-21.1
$$

where the range corresponds to the standard deviation in concrete permeability.

With $\mathrm{p}_{\mathrm{a}}=14.7$ psia, we have $\mathrm{p}_{0}=57.1-310$ psia $=42.4-295$ psig.

\section{E.6 Summary}

The mass diffusion approach yielded an IXC steady state pressure of 31 psig. The porous flow approach yielded a pressure of $42-295$ psig. If the diffusion coefficient used in the analysis is indeed a true diffusion coefficient (obtained with no pressure gradient across a concrete slab, only an $\mathrm{H}_{2}$ concentration gradient) then the actual pressure will be reduced below 31 psig since flow will also occur. If the diffusion coefficient is actually an overall mass transfer coefficient (i.e. some actual flow occurred during the test in which the coefficient was determined) then the porous flow approach should be considered equivalent to the diffusion approach, the permeability is near the high bound value. Given the similarity in the pressures

\footnotetext{
${ }^{\mathrm{e}}$ From NISTIR 7026: Condition Assessment for Concrete Nuclear Structures Considered for Entombment, July 2003, Kenneth A. Snyder. Exponent indicates mean (18.75) and one standard deviation ( \pm 0.75$)$.

${ }^{\mathrm{f}}$ Values for $20^{\circ} \mathrm{C}$ and atmospheric pressure from Heat Transfer by J.P. Holman, $6^{\text {th }}$ Edition, McGraw-Hill.
} 
predicted, this may be the case. In any event, we can say with a reasonable degree of conservatism that the steady state pressure will be less than, or equal to $\sim 31 \mathrm{psig}$. The time for this steady state to occur was not calculated for this analysis. However, it likely would be many years given the low gas generation rate.

Since the design pressure of the IXCs is 75 psig and tested at 125 psig (see Section 2.1 of this report), the IXCs will not over-pressurize or rupture after being stabilized in the concrete monolith (as long as the NUCFIL vent hole is only filled with concrete/grout and not aggregate). 


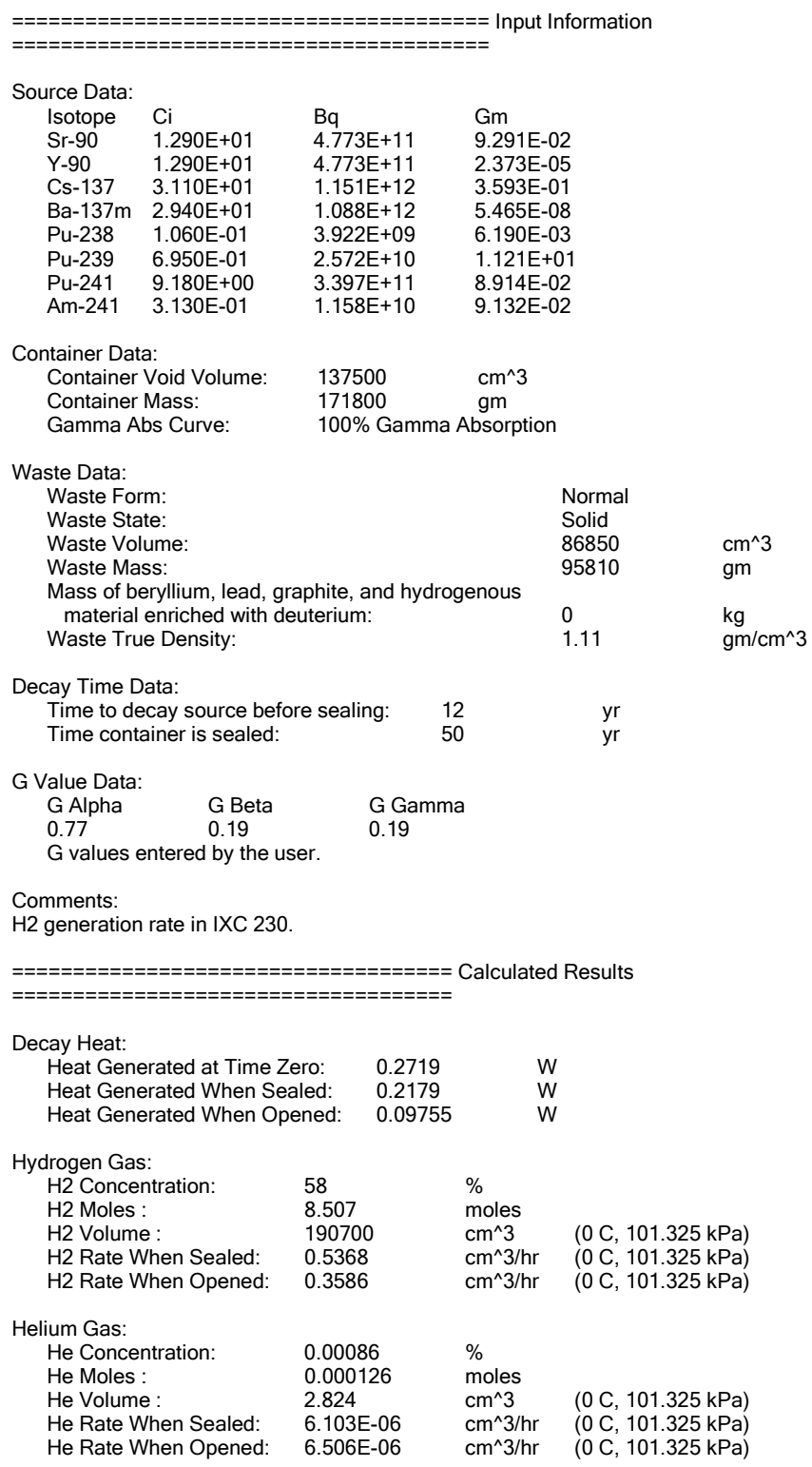

Exhibit E-1. Radcalc 4.0 Input and Calculated Results for IXC 230 


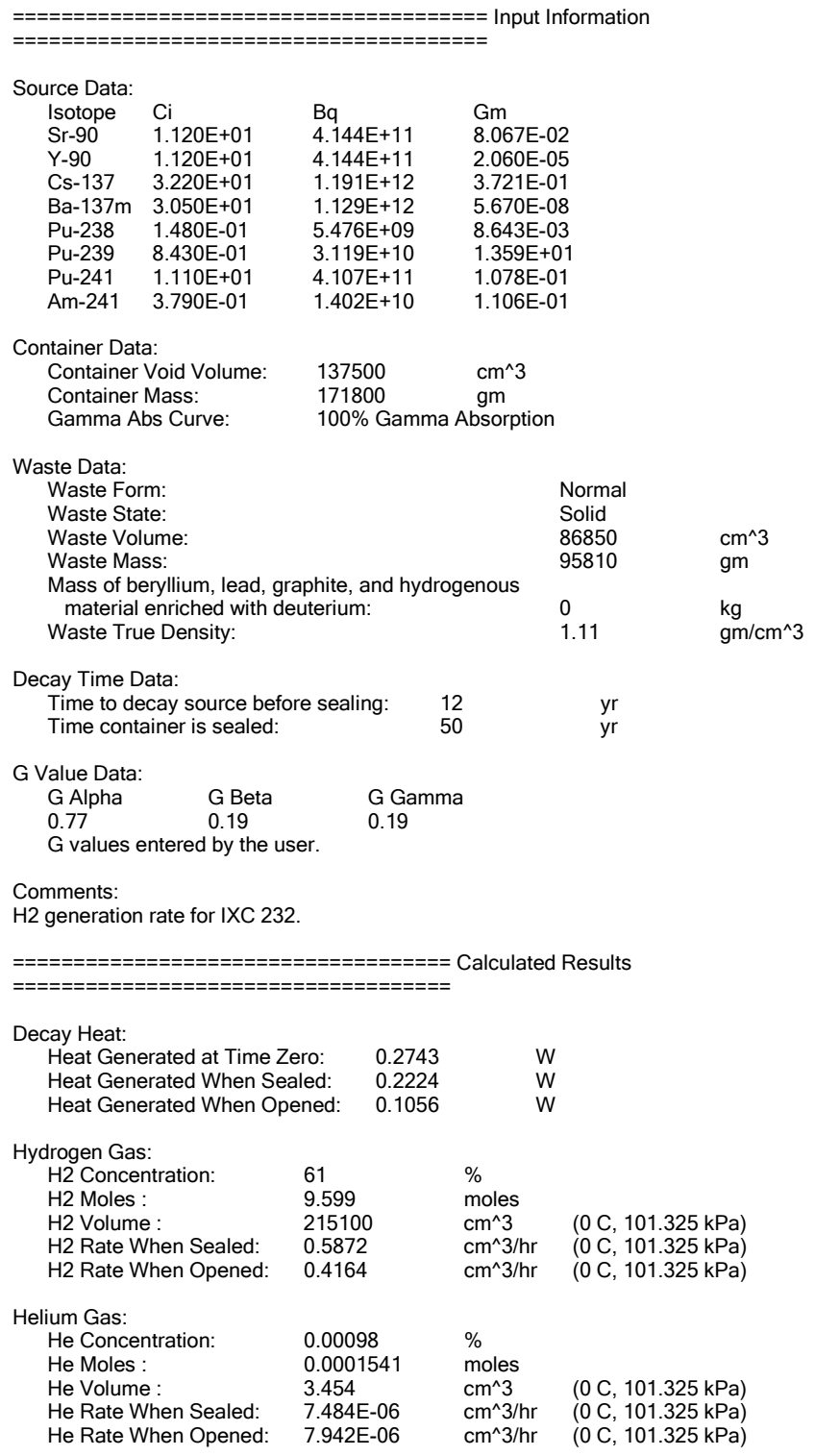

Exhibit E-2. Radcalc 4.0 Input and Calculated Results for IXC 232 


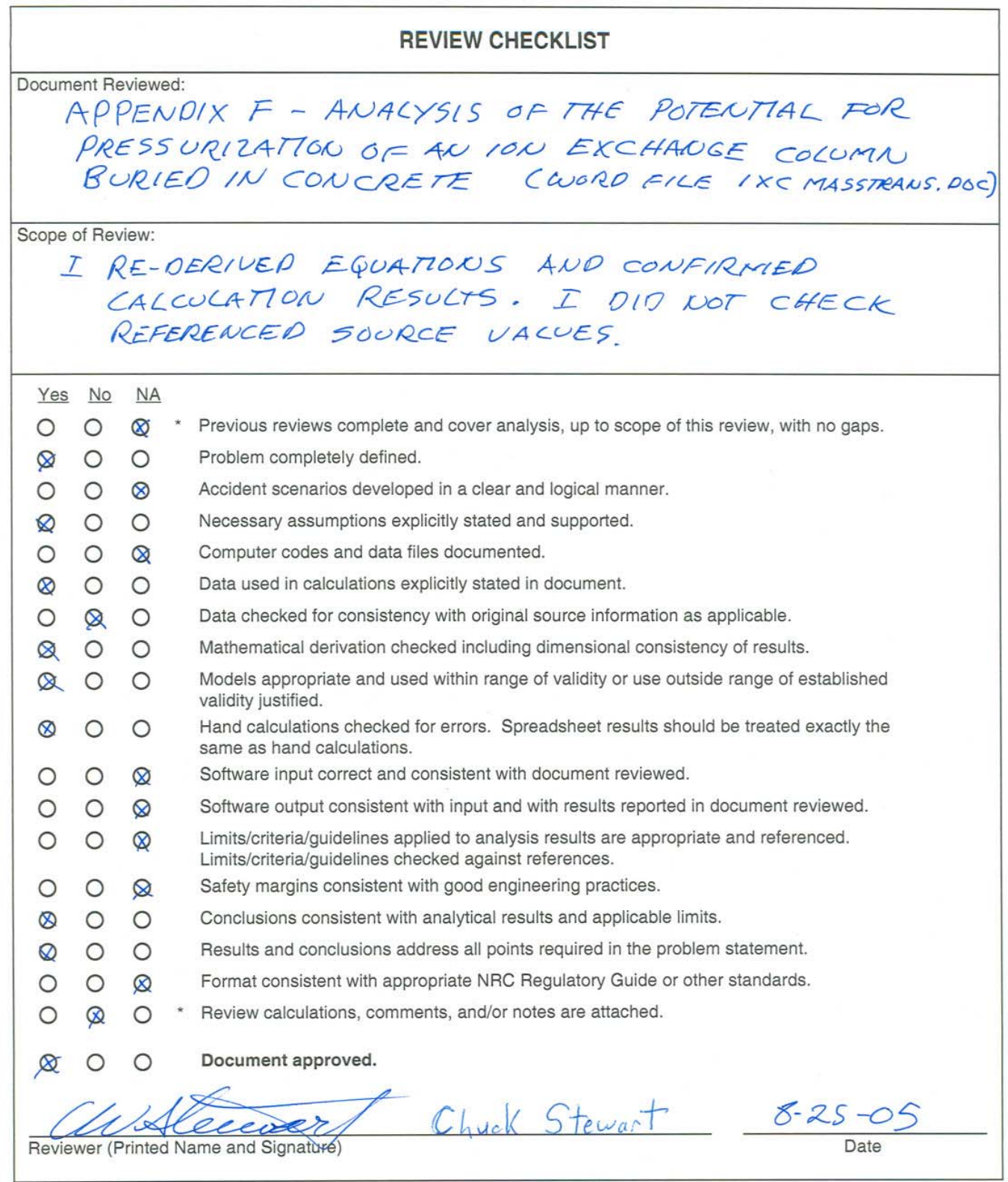

*Any calculations, comments, or notes generated as part of this review should be signed, dated and attached to this checklist. Such material should be labeled and recorded in such a manner as to be intelligible to a technically qualified third party. 


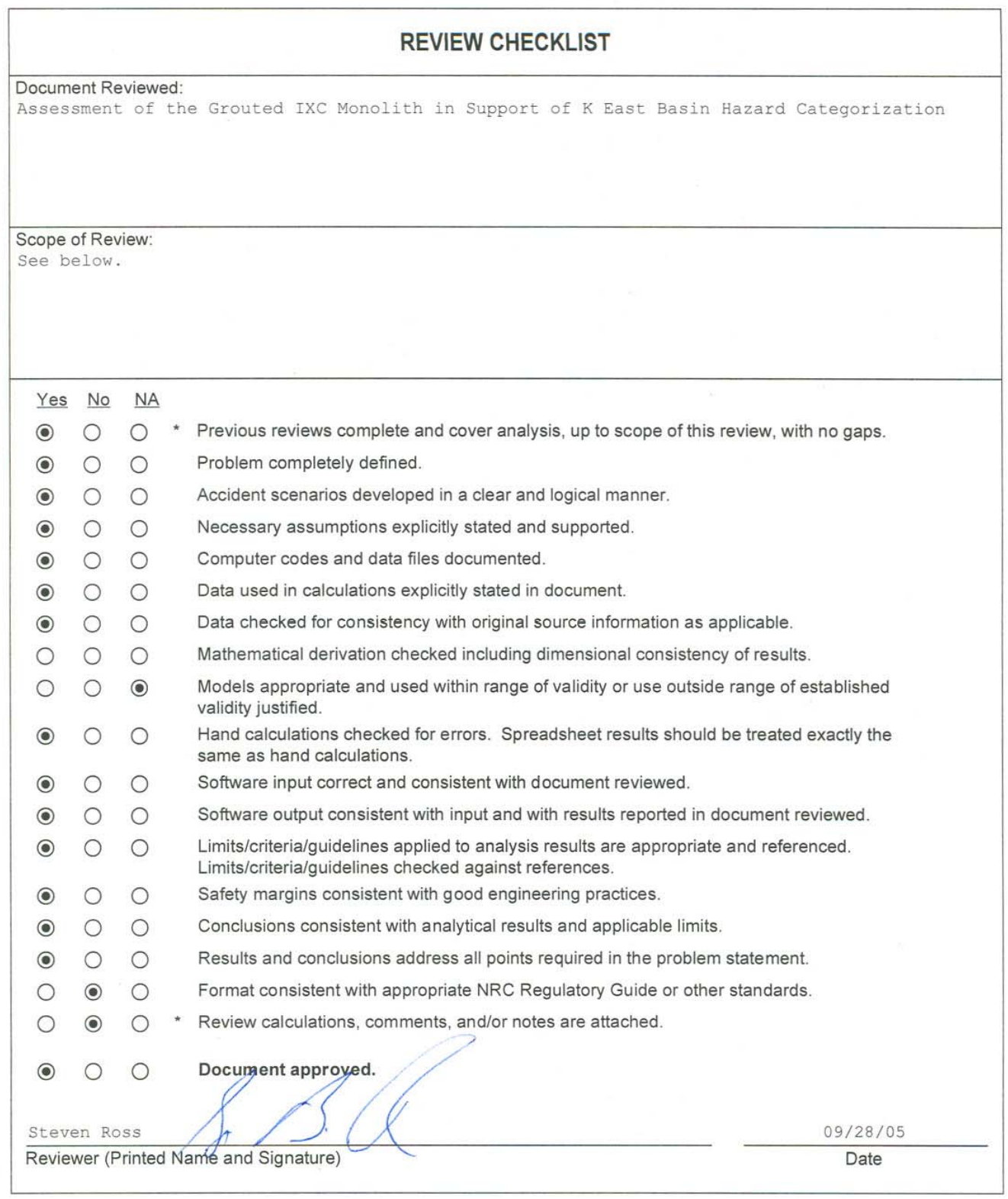

*Any calculations, comments, or notes generated as part of this review should be signed, dated and attached to this checklist. Such material should be labeled and recorded in such a manner as to be intelligible to a technically qualified third party. 


\section{Addendum I}

\section{Addendum to PNNL-15401 Regarding Structural Assessment of I-Beam Drop Accident}


This page intentionally left blank.

AD-ii 


\section{Addendum I \\ Addendum to PNNL-15401 Regarding Structural Assessment of I-Beam Drop Accident}

In PNNL-15401, one accident scenario considered was for an I-Beam to be dropped endon onto the top of the IXC monolith. It was conservatively assumed that the beam being dropped was a twenty foot long section of $\mathrm{W} 12 \times 336$. A review of the structural steel drawings for the area around the IXC monolith was performed and the heaviest beam found was a W21X96. In addition, the steel plate for the top of the monolith has been procured and is $1 / 2$ inch thick A36. The puncture calculations are being revised to reflect the different I-Beam size and the material properties of the steel plate. The other accident scenarios originally considered in PNNL-15401 were also reviewed to determine if the assumptions were still valid. These scenarios include the monolith drop accident, the boom drop accident, and the vehicle impact and subsequent fire accident. All assumptions for these accidents are still valid.

An I-Beam drop was considered to be one of the accidents most likely to cause damage to the IXC during demolition of the building. During an actual event such as this, the energy of the drop would be dissipated by deformation of the structure surrounding the IXCs, the grout, and the I-Beam itself. Some kinetic energy would likely still remain if the I-Beam rebounded. In this assessment, we have considered the drop energy to be entirely dissipated by shearing a hole through the steel plate on the IXC monolith and by crushing of some underlying concrete. An actual impact would result in significant plastic deformation of the steel plate over a much wider area than the end cross sectional area of the I Beam, but this part of the energy dissipation is not calculated. The effort required to conduct a more detailed evaluation and account for this dissipated energy would only be warranted if the conservative approach taken here did not show an adequate margin.

For the I-Beam drop accident, it is assumed that a twenty foot long section of W21X96 beam with a square end is dropped end-on onto the top of the monolith with a free fall height of twenty feet. An end-on impact orientation is the most conservative. The section of beam weighs 20 feet $\times 96$ pounds per foot $=1920$ pounds. The kinetic energy at impact is equal to the weight times the drop distance or 1920 pounds $x 20$ feet $=38,400$ foot pounds of energy. All of the energy is assumed to be dissipated by shearing a hole through the steel plate and crushing of underlying concrete. If the I-Beam were to impact at an angle other than perpendicular to the top surface, the damage due to the impact would be less because the I-Beam would rotate during the impact and lessen the impact force and the related deformation of the steel plate.

The actual deformation of the steel plate on the top of the monolith during the I-Beam impact event would be determined by the interaction of the I-Beam with the steel plate and the interaction of the steel plate and the concrete below. In order to simplify the analysis of this accident scenario, we are assuming a deformation pattern of the plate that provides a conservative estimate of the impact effects. The conservative approach used here is to assume the I-Beam punches out a rectangular area in the steel plate and crushes the concrete below. The depth of the penetration is assumed to be the steel plate thickness. If the deformation energy for the $1 / 2$ inch penetration is greater than the impact energy, no rupture of the steel is predicted. 
The area for the rectangular area has the same depth and width as the I-Beam. The depth and width of the beam is 21-1/8 inches and 9 inches respectively. This is a perimeter of 60.25 inches. A36 steel has a minimum yield strength of 36,000 psi and an ultimate strength of 58,000 to 80,000 psi. Lacking specifics on the A36 steel actually used to cover the monolith, a conservative value of 58,000 psi is used for the tensile strength and the tensile shear stress is taken as half of the tensile ultimate strength or 29,000 psi. The energy dissipated in punching out a plate with a perimeter of 60.25 inches is $1 / 2 \times 60.25$ inch x .5 inch x $29,000 \mathrm{psi}=436,800$ inch pounds or 36,400 foot pounds. While this is about 95 percent of the calculated impact energy, engineering judgment indicates that wider spread plastic deformation of the steel plate and plastic deformation of the I-Beam would surely dissipate much more energy. However, without a more sophisticated analysis, some energy dissipation from the concrete deformation is required.

Energy will be dissipated by crushing of the concrete below the plate. The concrete for the IXC cell enclosure has a minimum compressive strength of 3000 psi. However, the grout used in the lead cave has a compressive strength of 1500 psi. Crushing of the grout with a compressive strength of 1500 psi over the 21.125 by 9 inch by (assumed) $1 / 2$ inch deep volume would dissipate 1500 psi x 21.125 inches x 9 inches x $1 / 2$ inch or 142,000 inch pounds or 11,800 foot pounds of energy. The combined energy dissipation by the steel plate and the concrete is 48,200 foot pounds or $125 \%$ of the drop energy. The steel plate would not deform to failure where failure is considered rupture of the steel plate.

Again, the deformation zone of the concrete would be larger than the area used in these calculations. Furthermore, the crushing would not necessarily be confined to the top surface of the concrete ( $1 / 2$ inch assumed), but might be an accumulation of concrete deformations deeper in the concrete. No specific analysis was performed to evaluate what effect this deformation might have. However, if a rupture of an IXC were to occur, the analysis indicates that rupture of the steel plate is not predicted and no release of radioactivity would occur. If an accident such as the I-Beam drop onto the monolith were to actually occur, further D\&D activities would have to be suspended until an evaluation of the IXC's integrity could be completed.

The above analysis indicates no rupture of the $1 / 2$ inch thick A36 steel plate on the top of the IXC monolith due to the end-on impact of the largest credible I-Beam dropped from twenty feet. This analysis has made assumptions about the deformation mode and properties of the steel plate which are considered to be conservative. While the margin predicted by these calculations is only 25 percent, engineering judgment is that a much higher margin would exist if an actual IBeam drop test were conducted. 